Jurnal

\section{Pendidikan Sejarah}

Vol. 4 No. 2 Juli 2015

ISSN 2301-461X

Diterbitkan oleh

Program Studi

Pendidikan Sejarah Pascasarjana

Universitas Negeri Jakarta

Dewan Redaksi:

Ketua

Prof. Dr. Tuti Nuriah Erwin

Wakil Ketua

Kurniawati, S.Pd., M.Si.

Penyunting

Dr. Abdul Syukur, M.Hum.

Dirgantara Wicaksana , S.Pd., M.Pd.

Reviewer

Dr. Irene Maria Juli Astuti

\author{
Alamat Redaksi \\ Gedung M LT. 1 \\ Program Studi \\ Pendidikan Sejarah Pascasarjana \\ Universitas Negeri Jakarta \\ Jl. Rawamangun Muka \\ Jakarta Timur 13220
}

Keaslian tulisan ini menjadi tanggung jawab penulis. Redaksi berhak mengubah tulisan tanpa mengubah maknanya

\section{Daftar Isi}

Pembelajaran Sejarah dan Teacherpreneur

Abrar

Mencari Makna Dalam Sejarah:

Meninjau Kembali Historiografi Indonesiasentris

Sebagai Sumber Belajar Sejarah

Kurniawati

13-20

Strategi Pengelolaan Pembelajaran

Isu Materi Sejarah "Serupa" dan Sejarah Kontroversial

Djunaedi

21-35

Pendekatan Kontekstual: Suatu Pendekatan Alternatif

Pembelajaran Sejarah Di Sekolah Menengah Atas

Nur'aeni Marta

Pendekatan Dekonstruksi dalam Historiografi

Bahri

Public History: Suatu Tinjauan Pendahuluan

Jumardi

Reaktualisasi Nilai Sosial Budaya Melalui Pendidikan

Dan Pembentukan Karakter Bangsa Di Sekolah

Jumadi

$63-76$

Paradigma dalam Pembelajaran Sejarah Kontroversi

Sumardiansyah

77-88

Kurikulum Pendidikan di SD dan SMA

Pada Masa Orde Baru

Andi Riang Tati

89-102 



\title{
Pembelajaran Sejarah dan Teacherpreneur
}

\author{
Oleh : Abrar \\ Pendidikan Sejarah PPS UNJ
}

\begin{abstract}
The purpose ofthis paper reveals that the history teacher must be a teacherpreneur. The task of teacher preneur in implementing the learning history is to develop the ability to think creatively learners.It was motivated by the challenges of the times were more severe in all aspects of community life in the 21st century. The method used is literature study. Creative thinking skills can be cultivatedinthe teaching of historyby familiarizing students learn to solve problems. Through studying the history of learners solving problems is required to make a report based its findings workings historians. Teacherpreneur role is how to develop learning strategies that creative thinking was growing. Teacherpreneur is a teacher whois always doing good innovation to improve the knowledge and the learning process.
\end{abstract}

Key words: historical instruction, creative thinking, teacherpreneur.

\begin{abstract}
Abstrak
Tujuan dari tulisan ini mengungkapkan bahwa guru sejarah haruslah seorang teacherpreneur. Tugasnya dalam melaksanakan pembelajaran sejarah adalah menumbuhkembangkan kemampuan berpikir kreatif peserta didiknya. Hal itu dilatarbelakangi oleh tantangan zaman yang makin berat dalam segala aspek kehidupan masyarakat pada abad ke-21 ini.Metode yang digunakan adalah studi kepustakaan. Kemampuan berpikir kreatif dapat ditumbuhkembangkan dalam pembelajaran sejarah dengan membiasakan peserta didik belajar memecahkan masalah. Melalui belajar memecahkan masalah sejarah peserta didik dituntut untuk membuat laporan temuannya yang didasarkan cara kerja sejarawan. Peran teacherpreneur adalah bagaimana mengembangkan strategi pembelajaran agar berpikir kreatif itu tumbuh. Teacherpreneur adalah guru yang selalu melakukan inovasi baik untuk meningkatkan pengetahuannya maupun proses pembelajaran.
\end{abstract}

Kata Kunci: pembelajaran sejarah, berpikir kreatif, teacherpreneur.

\section{PENDAHULUAN}

Pendidikan merupakan komponen yang sangat penting bagi kehidupan manusia.Ia merupakan suatu kebutuhan mutlak yang harus dipenuhi sepanjang hayat. Tanpa pendidikan manusia tak akan mampu berkembang secara optimal dalam menjalani kehidupan. Sebab melalui pendidikan manusia dapat meningkatkan kecerdasan dan ilmu pengetahuannya.
Dengan kecerdasan dan ilmu pengetahuan itulah manusia menjalani hidup yang penuh dengan tantangan dan persaingan.

Pendidikan juga mempunyai peranan yang sangat penting dalam kehidupan suatu bangsa.Tidak ada bangsa yang mengalami kemajuan yang tidak didasarkan pada keberhasilan 
dalam pendidikan.Kemajuan apapun yang dicapai oleh suatu bangsa dalam sejarahnya menunjukkan karena besarnya perhatian terhadap dunia pendidikan. Cina yang sekarang tumbuh menjadi salah satu negara yang perekonomiannya pesat, tidak bisa dilepaskan dari kemajuan dalam bidang pendidikan yang dikembangkan selama beberapa dekade ini (Lanqing,2004: 24).

Keberhasilan dalam pendidikan tidak dapat dilepaskan dari peran guru dalam mendidik.Finlandia sukses dalam melakukan revolusi sistem pendidikan dengan membenahi lembaga pelatihan guru, agar guru bisa mendidik murid dengan baik(Kompas, 14 Maret 2013). Artinya keberhasilan Finlandia dalam bidang pendidikan kuncinya ada di tangan guru.

Persoalan yang terkait dengan guru merupakan persoalan yang sangat krusial di Indonesia. Meskipun telah dilaksanakan sertifikasi bagi guru-guru agar menjadi lebih professional, kenyataan menunjukkan program sertifikasi guru tidak mengubah mutu pendidikan dan prestasi belajar peserta $\operatorname{didik(Kompas,15}$ Maret 2013). Padahal tantangan ke depan makin lebih berat.

Ada beberapa tantangan yang bakal dihadapi di abad ke-21 ini yaitu; (1) cenderung terjadinya pertentangan integrasi ekonomi dengan fragmentasi politik, (2) globalisasi mewarnai seluruh kehidupan masyarakat, (3) terjadinya perubahan secara radikal dalam pasar tenaga kerja karena kemajuan sains dan teknologi, (4) meningkatnya penggunaan teknologi tingkat tinggi dalam industrialisasi, (5) munculnya gaya hidup baru yang mengandung ekses-ekses tertentu (Buchori, 2001: 27-31).
Tantangan zaman yang demikian berat itu membutuhkan orang-orang yang mempunyai kemampuan berpikir kreatif. Agar kemampuan berpikir kreatif itu tumbuh-kembang dikalangan generasi muda, maka salah satu upaya yang dilakukan dalam bidang pendidikan adalah melakukan perubahan kurikulum. Australia misalnya telah melakukan proses perubahan kurikulum sejak tahun 2009 dan kurikulum resmi yang digunakan adalah kurikulum 2012. Indonesia juga melakukan hal yang sama dengan diberlakukannya kurikulum 2013, meskipun dalam lingkup terbatas.

Berpikir kreatif dalam konteks pembelajaran sejarah merupakan sesuatu yang sangat penting.Berpikir kreatif itu tidak saja harus ada dikalangan peserta didik yang belajar, tetapi juga ada didalam diri guru yang mengajarkan sejarah. Memelajari peristiwa pada tanggal 11 September 2001 misalnya, ketika empat pesawat American Airlines dibajak dan pesawat tersebut digunakan menyerang beberapa bangunan di Amerika. Dua pesawat menyerang menara kembar World Trade Center di New York yang mengakibatkan runtuhnya kedua gedung tersebut dan memakan korban tewas dan luka-luka yang cukup banyak. Satu pesawat berusaha menyerang Pentagon dan satu pesawat diduga mau menyerang White House.

\section{Gambar-gambar} mengenai penyerangan ke menara kembar World Trade Center bermunculan di media massa, menjadi berita utama berbagai surat kabar dan televisi. Bahkan televisi tiada henti-hentinya menayangkan gambar penyerangan tersebut, namun gambar-gambar yang ditayangkan tersebut didominasi informasi yang penuh spekulasi.Guru dituntut untuk berpikir 
kreatif bagaimana agar informasi yang penuh spekulasi dapat diterima peserta didik sebagai pengetahuan sejarah.

Dalam konteks sejarah Indonesia hal yang sama juga pernah terjadi. Ketika pada tahun 1998 terjadi peristiwa penembakan terhadap mahasiswa yang dikenal dengan Persitiwa Semanggi, banyak spekulasi yang muncul mengenai peristiwa itu. Gambar peristiwa itu ditayangkan berulang kali dan dikomentari dengan berbagai informasi yang umumnya spekulasi, bukan informasi yang didasarkan fakta yang benar.Guru dituntut untuk kreatif dalam menjelaskan persoalan tersebut agar peserta didik tidak bingung. Kreatifnya guru bukan hanya dibutuhkan dalam menyampaikan isi materi pembelajaran, tetapi juga dalam memilih dan menerapkan metode pembelajaran yang sesuai dengan materi yang mau disajikan.

Berangkat dari pemikiran di atas maka ada dua permasalah pokok yang mau dikaji dalam tulisan ini; (1) Mengapa berpikir kreatif diperlukan dalam pembelajaran sejarah? (2) Guru yang bagaimanakah yang dapat mengembangkan pembelajaran berpikir kreatif tersebut?

\section{METODE PENELITIAN}

Pembelajaran menurut Gagne dan Briggs (dalam Suparman, 2012: 10) adalah suatu rangkaian peristiwa yang memengaruhi peserta didik sedemikian rupa sehingga perubahan perilaku yang disebut hasil belajar terfasilitasi. Rangkaian peristiwa tersebut dalam pembelajaran dirancang oleh guru.Berarti guru berperan dalam merangkai peristiwa yang membuat peserta didik terpengaruh. Terpengaruhnya peserta didik melalui proses pembelajaran yang dilakukan guru dalam rangka peserta didik mengalami perubahan perilaku.
Merancang rangkaian peristiwa itu setiap guru tentunya berbeda antara yang satu dengan yang lain, tergantung dari pengetahuan apa yang mau disampaikan kepada peserta didik. Pengetahuan tersebut bisa beraneka ragam seperti ekonomi, geografi, sosiologi, dan sejarah.

Pengetahuan termasuk pengetahuan sejarah bukanlah sesuatu yang ada begitu sajaatau ditemukan seperti permata atau artefak, tetapi suatu pengetahuan yang ada karena diciptakan oleh manusia. Pengetahuan adalahhasil konstruksi pemikiran manusia (Mintzes, Wandersee, Novak, 2005: 8).Sebagai suatu konstruksi pemikiran manusia berarti membutuhkan kreativitas untuk menciptakan hal itu.

Kreativitas terbentuk merupakan hasil dari berpikir kreatif.Berpikir kreatif menurut Evans (dalam Uno, Umar, dan Panjaitan, 2014: 113) menghasilkan pemikiran kreatif.Sedangkan menurut Halpern (2003: 398) berpikir kreatif adalah suatu proses kognitif yang terjadi dalam suatu konteks. Dengan demikian pemikiran kreatif seseorang dapat terjadi dalam suatu konteks tertentu.Konteks tertentu itu bisa terjadi dalam pembelajaran sejarah.Sebab setiap peristiwa pasti menunjukkan konteks tertentu dalam sejarah yang dipelajari peserta didik.

Apapun konteks pembelajaran sejarah yang bakal dihadapi peserta didik memerlukan seorang guru yang kreatif. Guru kreatif syarat pentingnya adalah guru yang mampu melahirkan gagasan baru, realistis dan orisinalitas (Ono, Umar, Panjaitan, 2014: 113).

Metode yang digunakan dalam mewujudkan tulisan ini adalah studi kepustakaan.Studi kepustakaan adalah serangkaian kegiatan yang berkenaan dengan metode pengumpulan data 
pustaka, membaca dan mencatat serta mengolah bahan penelitian (Zed: 2004, 3). Pengumpulan data dilakukan pada Perpustakaan Nasional dan Perpustakaan Universitas Negeri Jakarta. Selain itu data didapatkan juga dari perpustakaan online yang memberikan buku secara gratis seperti en.bookfi.org dan libgen.org.

Data yang didapatkan dikritisi dan diolah sesuai dengan kebutuhan untuk mewujudkan tulisan ini.Oleh karena itu tulisan ini banyak menggunakan sumber sekunder sesuai dengan ciri-ciri studi kepustakaan menurut Zed. Ciri-ciri lain dari studi kepustakaan itu adalah peneliti berhadapan langsung dengan teks dan data yang disajikan melalui studi kepustakaan yang bersifat siap pakai serta kondisi data tidak dibatasi oleh ruang dan waktu.Jadi data yang diolah bukanlah data yang didapatkan dari lapangan melalui pengumpulan angket, kuisioner, wawancara, ataupun catatan lapangan.

\section{HASIL DAN PEMBAHASAN}

Pembelajaran sejarah di sekolah khususnya tingkat Sekolah Menengah Atas (SMA) untuk mata pelajaran Sejarah Indonesia maupun Sejarah bertujuan mengembangkan kemampuan berpikir historis (historical thinking), keterampilan sejarah (historical skills) dan wawasan terhadap isu-isu sejarah (historical issues) (Lampiran III Permendik No. 59 Tahun 2014 tentang Kurikulum 2013 SMA/ MA).Kemampuan yang dikembangkan itu sesungguhnya dapat menumbuhkan kemampuan berpikir kreatif bagi peserta didik.

Agar kemampuan berpikir kreatif peserta didik tumbuh-kembang, pembelajaran sejarah yang diterapkan pada jenjang pendidikan menengah mestinya mengikuti cara kerja sejarawan.
Sejarawan dalam melakukan penelitian sejarah melalukan empat tahapan untuk dapat menghasilkan suatu tulisan sejarah. Pertama, heuristik ketika sejarawan berusaha mencari dan menemukan sumber untuk penelitian sejarah yang sedang dilakukannya.Kedua, kritik atau verifikasi. Pada tahap ini sejarawan melakukan kajian yang kritis tentang sumber yang ia gunakan dalam penelitian. Ketiga, interpretasi ketika sejarawan melakukan penafsiran terhadap fakta yang ia dapatkan dengan menggunakan konsep dan teori ilmu-ilmu sosial. Terakhir, penulisan yakni saat sejarawan menyajikan hasil penelitiannya dalam bentuk tulisan yang deskriptif analisis dengan menyajikan fakta-fakta sejarah menjadi fakta yang koheren.Berdasarkan tahapan tersebut pembelajaran sejarah sesungguhnya dapat menumbuhkan kemampuan berpikir kreatif.

Berpikir kreatif itu bisa ditumbuhkembangkan misalnya saat mereka dibiasakan untuk mencari sumber-sumber sejarah.Makin berkembangnya perpustakaan online di dunia maya memungkinkan peserta didik mencari sumber-sumber alternatif dalam belajar sejarah.Peserta didik bukan lagi disulitkan untuk mendapatkan sumber pembelajaran, tetapi dihadapkan pada persoalan bagaimana menyeleksi dari sumber yang berlimpah itu agar mendapatkan fakta-fakta sejarah yang dapat dipertanggungjawabkan secara ilmiah.Peran guru dalam hal itu adalah bagaimana melatih anak didik agar tahu bagaimana suatu sumber yang bersifat online dapat dipercaya dan dipertanggungjawabkan secara ilmiah. Sumber sejarah yang bersifat online itu dapat berbentuk e-book, e-journal atau blog yang dalam sajian tulisannya menunjukkan kaedah penulisan ilmiah 
dan pemiliknya mempunyai reputasi dan kredibilitas yang bagus.

Hal yang sama juga bisa dilakukan pada saat peserta didik menginterpretasikan fakta-fakta yang terdapat dalam sumber pembelajaran, peserta didik dapat menghasilkan ide-ide baru tentang tafsir dan makna dari fakta sejarah yang dipelajari. Peserta didik bisa menafsirkan fakta yang dipelajari dengan sudut pandang yang berbeda.Peserta didik dapat memberikan penjelasan alternatif tentang fakta sejarah yang didapatkan dari sumber pembelajaran. Peserta didik dapat melihat atau membuat hubungan-hubungan baru dari fakta yang didapatkannya dalam pembelajaran.

Pembelajaran sejarah semakin membutuhkan kreatifitas guru dan siswanya apabila dalam setiap topik pembelajaran dikembangkan pembelajaran yang berbasis masalah. Sebab pemecahan masalah dapat disebut kreatif apabila terdapat kondisi seperti; hasil pemikiran tersebut memiliki nilai kebaruan, menuntut motivasi dan ketekunan yang tinggi, dan ide-ide pemikiran itu diterima sebagai sesuatu yang bukan diterima secara umum (Newell, Shaw, Simon, 1959: 4). Artinya bahwa dalam pembelajaran agar terjadi proses berpikir kreatif, guru harus mampu mencari masalah sejarah yang jawabannya membutuhkan jawaban-jawaban baru atau ide-ide baru dari peserta didik. Hal itu bukanlah sesuatu yang mudah untuk dilakukan oleh guru, sebab guru mesti jeli melihat masalah sejarah yang mau dibahas dalam pembelajaran.

Kejelian guru dalam melihat persoalan sangat ditentukan oleh penguasaan materi yang harus dikuasai oleh guru tersebut.Penguasaan materi oleh seorang guru erat kaitannya dengan sejauhmana guru tersebut menguasai pengetahuan sejarah.Bahkan lebih dari itu guru tersebut hendaknya secara terus menerus memperbaharui pengetahuan sejarahnya. Kochhar (2008: 393) mengatakan bahwa seorang guru sejarah dapat disebut berkualitas apabila guru itu menguasai materi.

Selain itu yang harus dikuasai guru kata Kochhar adalah penguasaan teknik yaitu kemampuan guru menguasai berbagai metode dan teknik pembelajaran sejarah.Penguasaan berbagai metode dan teknik itu diperlukan agar guru mampu menerapkan metode dan teknik tertentu pada materi tertentu pula.Artinya dituntut kemampuan guru untuk menganalisis apakah metode yang mau diterapkan sudah sesuai dengan materi yang mau disajikan ke peserta didik.Oleh karena itu dalam suatu pembelajaran sejarah guru harus terbiasa untuk menjadi orang-orang kreatif.

Orang-orang kreatif itu biasanya sangat rajin, disiplin dan fokus (Lau, 2011: 217).Bagi guru dan peserta didik yang rajin mencari tahu dan memperdalam bacaan sejarahnya tentunya lebih berkembang kemampuan berpikir kreatifnya dibandingkan dengan yang bukan. Disiplin guru dan peserta didik dalam mendalami dan membaca sumber-sumber sejarah bakal dapat menumbuhkan kemampuan berpikir kreatif, apalagi kalau itu dilaksanakan dengan terfokus.Fokus dalam suatu hal menjadi sangat penting dalam memaksimalkan kemampuan kerja otak manusia. Sebab otak manusia tidak akan bekerja dengan baik kalau tidak fokus pada satu hal dalam melaksanakan sesuatu.James Borg (2010:222) menyatakan mengerjakan banyak tugas sekaligus merupakan musuh ingatan (pikiran). 
Ada beberapa prinsip dasar dalam melaksanakan strategi pembelajaran agar peserta didik kreatif (Halpern, 2003: 216):

1. Ajarkan peserta didik untuk memikirkan cara-cara yang berbeda untuk mencapai tujuan dan kemudian bagaimana memilih salah satu yang terbaik.

2. Banyak memberikan contoh dan latihan model dan praktik keterampilan kreatif.

3. Ajarkan peserta didik bagaimana mengajukan pertanyaan yang relevan dan bagaimana menemukan jawaban ketika ada masalah.

4. Mengevaluasi kualitas ide dengan konsekuensinya.

5. Memberikan penghargaan kepada peserta didik terhadap ide-ide mereka yang relevan dan membiarkan peserta didik tahu bahwa ide mereka berharga.

6. Menyiapkan peserta didik dalam situasi yang tidak terstruktur. Ajarkan peserta didik nilai ketekunan saat mereka gagal.

7. Menyiapkan peserta didik dengan rencana nyata untuk menemukan solusi. Ini berarti bahwa mereka harus dilatih cara-cara yang akan membantu mereka menemukan informasi yang relevan.

8. Mencegah peserta didik melakukan pelabelan atau mengkategorikan masalah atau solusi terlalu cepat dalam proses pemecahan masalah karena pelabelan cenderung mendorong terjadi obsesi.

9. Mengharapkan peserta didik bahwa kreatif itu hasil dari kerja keras, ketekunan, berbasis pengetahuan yang luas, dan mempunyai kemauan untuk terus berpikir meskipun telah menemukan solusi masalah.

10. Mendorong peserta didik mengambil risiko atas ketidaksesuaian masalah yang dipecahkan.

Menumbuhkembangkankemampuan berpikirkreatifdalam pembelajaran sejarah membutuhkan seorang teacherpreneur. Seorang teacherpreneur adalah seorang guru inovatif yang punya reputasi dalam memimpin peserta didiknya, tiada pernah meninggalkan ruangan kelas atau sekolahnya (http://www.teachingquality. org/sites/default/files/Teacherprenuer $\% 20$ Reach\%20and\%20Impact.pdf). Seorang teacherpreneur adalah guru kelas yang ahli yang mendidik peserta didiknya secara teratur, juga memiliki waktu, kesempatan, dan penghargaan untuk menyebarkan ide-ide dan prakteknya kepada rekanrekannya, serta administrator, pembuat kebijakan, orang tua, dan tokoh masyarakat (Berry, "Teacherpreneurs: A Bold Brand of Teacher Leadership for 21stCentury Teaching and Learning," http://portal. scienceintheclassroom.org/sites/default/ files/postfiles/science/2013berry-309-10. pdf). Berry menegaskan bahwa teacherpreneur adalah orang yang memegang peran kepemimpinan utama dalam menyusun atau membentuk kembali pedagogik dan kebijakannya, baik secara lokal maupun global (http:// www.von-online.be/sites/default/files/ Teacherpreneurs.pdf).

Sedangkan Bingham menyatakan bahwa teacherpreneurs adalah guru yang menulis buku, blog, dan artikel; memimpin komunitas pembelajaran virtual; merancang alat-alat teknologi baru dan permainan pendidikan; melakukan penelitian dan advokasi 
untuk kebijakan pendidikan yang efektif; memimpin reformasi dengan organisasi nirlaba dan organisasi berbasis masyarakat; membangun dan mencetak alat penilaian baru; dan menciptakansekolahgurupemimpin (http://gardnerwebb.edu/Assets/ gardnerwebb/academics/cild/teacher preneruship-notes1.pdf).

Seorang teacherpreneur adalah seorang guru yang berjiwa entrepreneur atau yang mempunyai karakteristik entrepreneur. Karakteristik entrepreneur seorang guru tersebut adalah kebebasan, percaya diri, tekad dan tekun, berorientasi pada tujuan, punya standar, kreatif, bertindak cepat, dan melek teknologi (Greene, 2011: 12).

Pertama, guru hendaknya punya kebebasan. Kebebasan yang dimiliki guru terkait dengan kebebasan ia dalam menjalankan profesinya. Ia tidak dibelenggu oleh aturan-aturan yang bersifat administratif yang menghambat kemampuannya untuk menghasilkan kinerja yang baik. Kalau dalam pembelajaran ada kurikulum yang bersifat nasional maka guru dalam melaksanakannya punya kebebasan membuat kurikulum untuk tingkat sekolah atau lingkup lebih kecil lagi yaitu kelas. Karena guru biasanya punya jam mengajar pada beberapa kelas. Masing-masing kelas tentu anak didik yang dihadapinya punya karakteristik yang berbeda-beda. Tidak mungkin karakteristik suatu kelas akan sama dengan kelas yang lainnya. Artinya guru harus merancang kurikulum yang berbeda antara satu kelas dengan kelas yang lain. Sederhananya guru mampu merancang silabus dan rencana pembelajaran sesuai dengan karakteristik peserta didiknya yang berbeda-beda. Guru dalam merancang pembelajaran harus bebas menentukan bagaimana pembelajaran yang mau diterapkan di setiap kelas yang diampunya.

Namun kebebasan yang dimilikinya itu harus juga diimbangi oleh kemampuan guru untuk melakukan refleksi diri, ketika dalam mengambil keputusan ternyata tidak mampu memfasilitasi agar anak didiknya mau belajar. Introspeksi diri perlu ditumbuhkembangkan. Guru harus mau mengakui bahwa apa yang telah dilakukannya itu merupakan suatu kekeliruan. Dari kekeliruan itu guru selanjutnya melakukan perubahan. Dengan demikianguru punya kemampuan untuk selalu belajar dari kekeliruan dalam mengambil keputusan.

Kedua, guru harus percaya diri. Guru dalam dirinya harus punya rasa percaya diri yang kuat. Ketika mengambil keputusan ia harus yakin dengan apa yang diputuskannya merupakan suatu kebenaran. Kebenaran yang diputuskannya itu kerangkanya untuk kebaikan. Kebaikan bagi dirinya, bagi anak didik, bagi teman sejawat, bagi sekolah, dan bagi masyarakat. Guru tidak boleh terjebak dengan hal-hal yang arahnya melakukan pembenaran. Sekali ia terjebak dalam pembenaran maka kompetensi pribadinya diragukan.

Ketiga, guru harus punya tekad dan ketekunan. Tekad dan ketekunan yang dimiliki guru hendaknya memperlihatkan bahwa ia seorang yang teguh dan gigih dalam upayanya mencapai tujuan. Guru harus punya pendirian, tidak mudah diombang-ambingkan oleh kepentingan yang tidak sesuai dengan tujuannya sebagai seorang pendidik. Godaan materi dan kekuasaan semakin kuat dengan berkembangnya kehidupan ekonomi suatu negara. Guru yang tidak punya 
pendirian yang teguh, maka bisa jadi mudah dilecehkan oleh anak didiknya atau lingkungannya, baik di sekolah atau masyarakat.

Ketekunan menjalani profesinya juga harus tumbuh terus. Semakin ia tekun dengan profesinya semakin cinta ia akan profesinya. Demikian tekunnya ia melakukan profesinya sehingga apa yang dilakukannya tidak selalu harus diimbangi oleh pamrih. Baginya yang penting bagaimana profesinya benarbenar merasuk dalam sanubarinya. Imbalan atau pamrih bukan tujuannya. Hidupnya ia abdikan untuk kepentingan profesinya. Berdasarkan keteguhan dan ketekunannya itulah akhirnya orang lain akan mencarinya, sebab ia sudah mumpuni. Diakui kompetensinya sebagai seorang guru yang profesional. Kompetensi yang diakui itulah yang menentukan bagaimana lembaga pendidikan menghargai profesinya secara material.Artinyalembaga pendidikan yang membutuhkan guru dalam melakukan rekrutmen tidak saja berpatokan pada ijazah dan indeks prestasi yang dimiliki calon guru, tetapi jauh lebih penting lagi dari segi kompetensinya sebagai pendidik professional.

Keempat, guru harus berorientasi pada tujuan. Guru yang dalam menjalankan profesinya hendaknya fokus pada tujuan yang mau dicapai. Kalau ia mau mencapai tujuan nasional sebagaimana yang terdapat dalam kurikulum nasional, maka perhatiannya fokus kesitu. Ranah belajar berdasarkan taksonomi Bloom ataupun yang disempurnakan Anderson, diimprovisasi oleh guru agar sesuai dengan tujuan nasional yang ingin dicapai.

Kelima, guru harus punya standar. Sebagai guru yang profesional ia harus punya standar dalam menjalankan profesinya. Standar yang dibuatnya harus yang dapat diukur yang kerangkanya untuk mencapai tujuan. Ia tidak boleh menjauh dari standar yang telah dibuatnya. Standar yang dibuatnya itulah yang memotivasinya agar tujuan tercapai.

Keenam, guru harus kreatif.Kehidupan yang semakin kompleks dan tantangan yang makin meningkat membutuhkan orang-orang kreatif.Guru yang kreatif adalah guru yang mampu secara berkelanjutan mengembangkan hal-hal baru dalam melaksanakan pembelajaran agar tercapai tujuan yang diinginkan. Ia harus mampu mengemas bagaimana pembelajaran menjadi menyenangkan dan menarik bagi anak didik. Sebab kalau tidak menarik anak didik bisa jadi tidak memperhatikan apa yang dikemukakan guru. Anak didik bisa jadi akan beralih mencari melalui web yang terdapat pada jaringan internet. Guru kreatif hendaknya mampu membuat solusi yang menarik ketika menghadapi masalah dalam pembelajaran di kelas. Guru yang kreatif juga sekaligus menjadi model bagi anak didik agar anak didik tumbuh menjadi orang-orang yang kreatif.

Ketujuh, guru harus mampu bertindak cepat. Dalam hal itu guru mesti mampu bertindak cepat ketika dihadapkan pada persoalan dan tantanganyang terjadi dalam pembelajaran.Bukan hanya itu, bertindak cepat ini juga sudah tercermin ketika mulai dari merencanakan pembelajaran. Ia harus mampu mengantisipasi perkembangan yang terjadi di dunia khususnya dalam konteks pendidikan. Sebab kalau guru sering terlambat dalam bertindak maka yang bersangkutan akan ditinggal, dan orang beralih ke yang lain yang menjadi pesaingnya. 
Kedelapan, guru harus melek teknologi. Ini menjadi hal sangat krusial ditengah kemajuan teknologi komunikasi dan informasi. Dengan kemampuannya dalam menguasai teknologi, maka ia mampu melakukan improvisasi dalam pembelajaran. Segala bentuk pembelajaran bisa harusnya ia kembangkan. Kalau pembelajaran dalam kelas maka ia mampu memanfaatkan teknologi yang tersedia sehingga pembelajaran menjadi efektif. Sebaliknya kalau harus dihadapkan pada pembelajaran jarak jauh, maka ia mampu mengemas pembelajaran itu sesuai dengan konteksnya. Pengemasan itu disesuaikan dengan perkembangan teknologi komunikasi dan informasi yang tersedia.

Karakteristik teacherpreneur tersebut baru mempunyai arti penting bagi peserta didik jika guru memiliki nilai melayani didalam dirinya. Sebab guru adalah pemimpin bagi peserta didiknya.Sebagai pemimpin guru harus melayani peserta didiknya. Oleh karena itu guru sebagai pelayan mempunyai sifat; listening, empathy, healing, awareness, persuasion, conceptualization, foresight, stewardship, commitment to the growth of people, building community (Smith,www.carolsmith. Usdownloads640greenleaf.pdf).

Pertama, sifat listening seorang guru menjadi sangat penting sebab dalam mendidik peserta didik pasti banyak ditemukan masalah. Menghadapi berbagai masalah maka guru harus mau mendengarkan segala bentuk keluhan, masukan, pandangan, dan kritikan yang datang terutama dari anak didiknya.

Kedua, guru hendaknya punya empati. Empati mesti dibangun guru terhadap anak didiknya. Dengan empati berarti guru menghargai anak didiknya. Guru menerima anak didiknya sebagai manusia yang perlu dihargai.

Ketiga, guru punya sifat healing maksudnya seorang guru harus mampu melihat anak didiknya sebagai sesuatu yang utuh dimana anak didik punya sifat, karakter, dan perilaku masing-masing. Guru harus memahami anak didiknya punya kelebihan dan kekurangan.

Keempat, guru mempunyai awareness maksudnya guru dalam melayani anak didiknya harus dengan penuh kesadaran. Sadar bahwa yang dilayani anak didik yang punya potensi untuk tumbuh dan berkembang.Tanpa kesadaran maka guru bisa kehilangan kesempatan dalam memimpin anak didiknya.

Kelima, guru bersifat persuasion maksudnya guru dalam memimpin anak didiknya hendaknya tidak menggunakan kekuasaannya agar anak didiknya mau mengikuti apa yang diinginkan guru, tetapi guru hendaknya menggunakan bujukan. Artinya guru melakukan pendekatan yang bersifat pribadi, tidak bersifat sewenangwenang. Tidak sok kuasa.

Keenam, guru punya sifat conceptualization maksudnya seorang guru harus mampu membuat solusi terhadap masalah yang dihadapi saat mendidik peserta didiknya. Guru tidak boleh membiarkan suatu masalah mengambang tanpa ada penyelesaian.

Ketujuh, guru punya foresight maksudnya seorang guru harus punya pandangan jauh ke depan. Ia hendaknya mampu memberi inspirasi bagi anak didiknya bagaimana kehidupan manusia di masa depan yang bakal dihadapi.

Kedelapan, guru punya sifat stewardship maksudnya sebagai pemimpin bagi anak didiknya guru tidak boleh perhatiannya hanya pada seseorang, tetapi haruslah 
seluruh anak didiknya di dalam kelas. Guru harus menjadikan anak didiknya sebagai teman. Sebagai teman setiap orang didalam kelas harus mempunyai tanggungjawab untuk menentukan visi, misi dan tujuan yang mau dicapai.

Kesembilan, guru punya commitment to the growth of people maksudnya seorang guru mampu membangun kebersamaan dalam kelas. Dengan adanya kebersamaan pembelajaran bisa berlangsung menyenangkan. Suasana menyenangkan dalam pembelajaran dapat membangkitkan inspirasi bagi anak didik.

Kesepuluh, guru punya building community dimana seorang guru haruslah sanggup membangun suatu komunitas belajar. Dengan membangun komunitas belajar diharapkan anak didiknya secara berkelanjutan tumbuh kebiasaan belajar yang datang dari dalam dirinya. Belajar bagi anak didik pada akhirnya menjadi sebuah kebutuhan. Anak didik akan merasa bahwa tanpa belajar mereka merasa kehilangan sesuatu.

Seorang teacherpreneur mempunyai tiga fungsi utama yaitu fungsi inovasi, fungsi menanggung resiko, dan fungsi membangun organisasi (Sethi:www. du.ac.infileadminDUAcademicscourse_ materialEP_01.pdf). Pertama, fungsi inovasi. Seorang teacherpreneur memanfaatkan informasi, pengetahuan atau intuisinya untuk selalu berusaha menghasilkan sesuatu yang baru dalam melaksanakan pembelajaran. Menghasilkan sesuatu yang baru itu bisa saja bentuknya berupa ciptaan (invention) dan dapat pula berupa pembaharuan (innovation).

Kedua, fungsi menanggung resiko. Teacherpreneur selalu siap menanggung resiko dari setiap keputusannya dalam menghasilkan suatu kebaruan dalam pembelajaran. Menanggung resiko itu bukanlah seperti penjudi, melainkan telah memperhitungkan resiko tersebut sebelum keputusan melakukan pembaruan dilaksanakan.

Fungsi terakhir, membangun organisasi. Teacherpreneur mempunyai kemampuan mengelola sumber daya manusia, bahan dan sumber-sumber lain. Ia harus mampu merencanakan dan mengontrol. Selain itu ia harus juga sanggup menggunakan kualitas kepemimpinannya membangun tim, menghasilkan sumber-sumber dan memecahkan masalah.

\section{KESIMPULAN}

Pembelajaran sejarah membutuhkan cara-cara baru dan ide-idebaru sebagai bagian dari upaya menumbuhkembangkan kemampuan berpikir kreatif. Kemampuan berpikir kreatif itu dibutuhkan peserta didik dalam kehidupan mereka saat mereka menghadapi berbagai tantangan sekaligus harapan. Tantangan dan kompleksitas kehidupan di masa depan dalam dunia pendidikan memerlukan guru-guru sejarah yang kreatif, mau berinovasi, dan berani mengambil resiko demi mengembangkan potensi anak didiknya sebagai manusia yang punya keunggulan.

Sebagai teacherpreneur guru sejarah adalah pemimpin guru inovatif yang membudayakan hubungan erat dengan masyarakat demi untuk keuntungan siswanya, siap berinovasi dan memperoleh keuntungan dari alat-alat tekonogi baru, dan memperkuat pendidikan publik melalui kebijakan dan komunitas masyarakat. Sebagai teacherpreneur guru sejarah harus selalu mengembangkan kompetensi dirinya agar ia tetap eksis dan 
mampu bersaing dengan yang lainnya. Tanpa terus menerus mengembangkan kompetensi diri maka ia akan sulit untuk bertahan ditengah-tengah kehidupan dunia yang makin ketat dan keras.

Namun demikian guru harus tetap tumbuh dalam dirinya sifat kemanusiaan. Sisi-sisi kemanuasiaan ini menjadi penting dalam konteks guru sebagai pemimpin di dalam kelas. Sisi-sisi kemanusiaan itu sangat berarti bagi seorang guru sejarah sebab pembelajaran sejarah sesungguhnya sarat akan nilai-nilai itu. Banyak hal dalam sejarah yang memperlihatkan nilai-nilai kemanusiaan yang tidak mungkin didapatkan dari belajar yang menggunakan teknologi informasi dan komunikasi. Bagaimanapun pembelajaran sejarah tetap membutuhkan guru sebagai fasilitator dan motivator untuk menumbuhkan nilai-nilai kemanusiaan yang terkandung dalam sejarah kehidupan manusia.

\section{Daftar Pustaka}

Berry, Barnett.“Teacherpreneurs: A Bold Brand of Teacher Leadership for 21st Century Teaching and Learning," http://portal. scienceintheclassroom.org/sites/default/ files/postfiles/science/2013berry-309-10. pdf(diakses tanggal 27 Juli 2015).

. "Teacherpreneurs A More Powerful Vision for the Teaching Profession."// www.von-online.be/sites/default/files/ Teacherpreneurs.pdf(diakses tanggal 26 Juli 2015).

Bingham, C. Steven. "What is a Teacherpreneur? Ask Sarah Henchey."http:// gardnerwebb.edu/Assets/gardnerwebb/ academics/cild/teacherprenerushipnotes1.pdf (diakses tanggal 27 Juli 2015).
Borg, James. Rahasia Kekuatan Pikiran terjemahan Amanda Setiorini. Jakarta: Serambi Ilmu Semesta, 2010.

Buchori, Mochtar. Pendidikan Antisipatoris. Yogyakarta: Kanisius, 2001.

Center for Teaching Quality Teacher Transforming Teaching. "Teacherpreneurs and Teachers in Residence: Rich and Impact." http://www.teaching quality.org/ sites/default/files/Teacherprenuer $\% 20$ Reach\%20and\%20Impact.pdf (diakses tanggal 26 Juli 2015).

Greene, Chyntia L. 21st Century Business, 2ndEdition.Mason, $\mathrm{OH}$ : South-Western Cengage Learning, 2011.

Halpern, Diane F. Thought \& Knowledge An Introduction to Ctitical Thinking. New Jersey: Laurence Erlbaum Associates, 2003.

Hisrich, Cs. "Definition of Entrepreneur Tod a y." ht t p://sbaer.uca . edupublicationsentrepreneurshippdf11. pdf (diakses tanggal 7 Mei 2013).

Kochhar, S. K. Pembelajaran Sejarah Teaching Of History terjemahan Purwanta dan Yovita Hardiwati. Jakarta: Grasindo, 2008.

Lanqing,Li. Education for 1.3 Bilion. Beijing: Foreign Language Teachingand Research Press, 2004.

Lau, Joe Y. F. An Introduction To Critical Thinking And Creativity Think More Think Better. New Jersey: John Wiley \& Sons Inc., 2011.

Mintzes, Joel J., James H. Wandersee, Joseph D Novak. Assessing Science Understanding A Human Contructivist View.San Diego: Elsevier Academic Press, 2005.

Sethi, Jyotsna. "Lesson-1 Entrepreneur and Entrepreneurship." www.du.ac. infileadminDUAcademicscourse materialEP_01.pdf (diakses tanggal $\overline{7}$ Mei 2013). 
Smith." Servant Leadership: The Leadership Theory of Robert K. Greenleaf," www.carolsmith. usdownloads640greenleaf.pdf(di akses tanggal 6 Mei 2013).

Suparman, M. Atwi. Panduan Para Pengajar \& Inovator Pendidikan Desain Instruksional Modern. Jakarta: Erlangga, 2012.

Uno, Hamzah B, Masri Kudrat Umar, dan Keysar Panjaitan. Variabel Penelitian Dalam Pendidikan Dan Pembelajaran. Jakarta: Ina Publikatama, 2014.

"Tunda Kurikulum 2013 Rekomendasi Majelis Guru Besar ITB." Kompas, 14 Maret 2013.

“Anggaran Pendidikan 20 Persen Tak Efektif Bank Dunia Sarankan Sistem Pendidikan Guru Diubah." Kompas,15 Maret 2013.

Lampiran III Peraturan Menteri Pendidikan No. 59 Tahun 2014 tentang Kurikulum 2013 SMA/MA. 


\title{
Mencari Makna Dalam Sejarah: Meninjau Kembali Historiografi Indonesiasentris Sebagai Sumber Belajar Sejarah
}

\author{
Oleh : Kurniawati \\ Pendidikan Sejarah PPS UNJ
}

\begin{abstract}
This article describes the historiography toward Indonesia after independence and its relevance to the teaching of history at the time. The Method used in writing this article is the research literature. Writing the history of Indonesia, which has a style Indonesiacentric is an issue that has always promoted in the historiography Indonesia. Since independence in 1945, a form of history writing seeks embodied Indonesiacentric. Therefore it seeks a National History Congress was held to formulate the form of historiography Indonesiasentric but Congress was not fully able to formulate clearly. Historiografi Indonesia finally caught up to the political interests that lead to the deconstruction of old regime history. History teacher thus becomes very important in answering the anxiety people especially students in learning history.Curriculum 2013 gives greater space to the history teachers to design learning history allows students not only rely on textbooks but explores a variety of sources and historiography are available.
\end{abstract}

Key words: Indonesiacentris, historiography, History Teaching and Learning

\begin{abstract}
Abstrak
Artikel ini memaparkan arah historiografi Indonesia setelah kemerdekaan dan relevansinya dengan pembelajaran sejarah pada saat ini.Metode yang digunakan dalam penulisan artikel ini adalah penelitian kepustakaan. Penulisan sejarah Indonesia yang memiliki corak Indonesiasentris merupakan isu yang selalu mengemukan dalam historiografi Indonesia.Sejak kemerdekaan 1945, suatu bentuk penulisan sejarah Indonesiasentris berupaya diwujudkan. Untuk itu suatu Kongres Sejarah Nasional pun dilaksanakan untuk merumuskan bentuk historiografi Indonesiasentris tetapi kongres itu tidak sepenuhnya dapat merumuskan dengan jelas.Historiografi Indonesia pada akhirnya terjebak kepada kepentingan politik sehingga penggantian rezim menyebabkan terjadinya dekonstruksi sejarah rezim sebelumnya.Peran guru sejarah dengan demikian menjadi sangat penting dalam menjawab kegelisahan masyarakat terutama siswa dalam mempelajari sejarah.Kurikulum 2013 memberi ruang yang lebih luas kepada guru sejarah untuk mendesain pembelajaran sejarah yang memungkinkan siswa tidak hanya mengandalkan buku teks tetapi mengeksplorasi berbagai sumber dan historiografi yang tersedia.
\end{abstract}

Kata Kunci: Indonesiasentris, Historiografi, pembelajaran sejarah

\section{PENDAHULUAN}

Setelah Proklamasi Kemerdekaan Indonesia 17 Agustus 1945, Indonesia sebagai negara yang baru merdeka berjuang membentuk identitasnya yang baru sebagai bangsa yang merdeka. Pemerintah pun memandang perlu menuliskan kembalisejarahIndonesiayang sampai saat itu masih mengacu kepada penulisan-penulisan sejarah yang ditulis oleh sejarawan-sejarawan Belanda yang sangat Belandasentris atau Eropasentris yang menempatkan orang-orang Belanda sebagai aktor utama sedangkan bangsa Indonesia hanya sebagai figuran yang 
tidak terlalu berarti. Penulisan sejarah yang Belandasentris semacam itu menjadikan orang-orang Belanda sebagai pihak yang berjasa bagi Indonesia karena telah menjadikan bangsa yang dijajahnya tersebut beradab. Sejarawan-sejarawan Belanda ini-sebagaimana sejarawansejarawan lainnya di dunia-pada abad ke-19 hingga pertengahan abad ke-20 sangat terpengaruh oleh pemikiran Ranke mengenai sejarah yang berkembang sejak abad ke-19. Semboyan Ranke yang terkenal wie es eitgentlich gewesen ist menyebabkan penulisan sejarah sangat mementingkan dokumen primer, fokus pada sejarah politik dan orang-orang besar dan kemudian sejarah nasional.

Penulisan sejarah yang mengacu kepada penulisan sejarah nasional mendapat tantangan besar di Eropa terutama setelah Perang Dunia II berakhir karena sejarah nasional justru dianggap sebagai pemicu peperangan. Penulisan sejarah nasional yang menekankan aspek politik mulai dicarikan alternatifnya pada penulisan-penulisan sejarah yang menekankan pada topik-topik sosial dan budaya. Penulisan sejarah alternatif semacaminidikembangkanolehsejarawansejarawan annales dari Prancis yang dipelopori oleh March Bloch dan Lucien Febvre. Aliran annales memopulerkan penulisan sejarah sosial yang bersifat long duree dan memakai pendekatan ilmu-ilmu sosial. Muncul pula aliran postmodernis yang dipelopori tokoh-tokoh seperti Hayden White, Jean-Francois Lyotard, Michael Foucault, Jacques Derrida dan Frank Ankersmith. Postmodernisme mene-kankan perhatiannya pada naratif, epistemologi, dan kebenaran. Dalam aliran posmodernisme atau posmo, realitas ada dalam bahasa dan permainan kata dengan demikian semua fakta yang ditulis dalam sejarah kebenarannya adalah relatif.
Sedikit berbeda dengan tren yang berlangsung di Eropa dan Amerika, Indonesia dan banyak negara-negara di Asia-Afrika yang baru saja lepas dari kolonialisme setelah 1945 justru tengah berusaha merumuskan sebuah sejarah nasional sebagai identifikasi sebuah identitas bangsa yang baru merdeka. Membangun kesadaran masyarakat bahwa Indonesia adalah sebuah nasion merupakan isu nasional pada 1950 sehingga penulisan sejarah nasional merupakan keniscayaan. Kebutuhan untuk menghasilkan sebuah sejarah nasional inilah yang mendorong diadakannya Kongres Sejarah Nasional pada 1957. Terjadi perdebatan dalam kongres ini antara Muhammad Yamin dan Soedjatmoko mengenai bagaimana sejarah nasional harus ditulis. Muhammad Yamin berpendapat bahwa penelitian ilmiah seharusnya mengarah kepada interpretasi nasionalis yang berguna untuk memperkuat kesadaran nasional sementara Soedjatmoko berpendapat bahwa nasionalisme akan menghalangi pendekatan ilmiah. Menangnya pendapat Yamin dalam kongres itu menandakan kuatnya sentimen nasionalisme pada saat itu di Indonesia.

Artikel ini akan memaparkan arah historiografi Indonesia setelah kemerdekaan dan relevansinya dengan pembelajaran sejarah pada saat ini. Membahas arah historiografi Indonesia pascakemerdekaan memerlukan penjelasan mengenai tren historiografi dunia sejak abad ke-20.

\section{METODE PENELITIAN}

Sejarawan Inggris Collingwood (1985: xxxix-xliii) mengatakan bahwa sejarah adalah suatu bentuk penelitian atau inquiri. Sejarah menurutnya adalah sains sehingga memungkinkan di dalamnya untuk mengajukan pertanyaan- 
pertanyaan dan kemudian berusaha mencari jawabannya. Maka ia mempunyai bentuk pemikiran yang khusus sehingga untuk menjawab sifat, objek, metode serta bentuk pemikiran haruslah ahliahli sejarah dan mempunyai pengalaman dalam pemikiran sejarah.

Rowse (2014:34) mendefinisikan sejarah sebagai catatan kehidupan manusia di masyarakat dalam lingkungan geografi dan fisik mereka. Unsur manusia dengan demikian adalah hal yang memegang peranan penting karena hanya kehidupan manusia yang dapat dicatat sebagai sejarah.

Historiografi menurut Abdulah (1985:XV) adalah hasil penulisan sejarah. Penulisan sejarah adalah puncak dari segala-galanya karena apa yang dituliskan adalah sejarah. Historiografi di setiap tempat berbeda karena historiografi mengekspresikanbudayadankeprihatinan sosial masyarakat atau kelompok masyarakat yang menghasilkannya.

Kochhar (2010:10-11) mengatakan bahwa pembelajaran sejarah bersifat kronologis, yang merupakan kunci dalam memahami masa lalu dan masa sekarang.

Pendidikan sejarah dengan demikian dapat disimpulkan sebagai suatu cara memperkenalkan masa lampau atau suatu peristiwa yang terjadi pada masa lampau secara kronologis sehingga siswa dapat mengetahui akibat yang ditimbulkan oleh peristiwa-peristiwa masa lampau itu pada masa sesudahnya dan juga pada masa kini.

Metode yang digunakan dalam penulisan artikel ini adalah penelitian kepustakaan. Zed (2008:1-2) mengatakan bahwa penelitian pustaka atau library research adalah memanfaatkan sumber perpustakaan untuk memeroleh data penelitiannya, membatasi kegiatannya hanya pada bahan-bahan koleksi perpustakaan saja tanpa memerlukan riset lapangan.

\section{HASIL DAN PEMBAHASAN}

\section{Tren Historiografi Dunia Abad ke-20}

Sejak memasuki abad ke-20, mulai muncul ketidakpuasan terhadap bagaimana sejarah telah ditulis terutama di Eropa. Pada saat itu warisan Ranke yang kuat mengenai pentingnya sumber primer dianggap tidak lagi memuaskan bagi sebagian sejarawan. Sebagai alternatif terhadap penulisan sejarah model Ranke yang disebut sebagai empirisme dan rekonstruksionisme muncul aliran baru yang disebut konstruksionisme yang dipelopori oleh Karl Marx, Auguste Comte dan Herbert Spencer yang tidak puas dengan penjelasan sejarah yang deskriptif-naratif. Konstrutivisme ini kemudian diteruskan pada tahun 1920an oleh Gerakan Sejarah Baru atau New History Movement yang dihubungkan dengan Jurnal Annales di Prancis dan kelompok Sejarawan Amerika Baru atau New American Historian yaitu Frederick Jackson Turner, Charles Beard, James Harvey Robinson dan Vernon L.Parrington.

Pada tahun 1950-1960an muncul sejarawan yang dengan sadar memposisikan dirinya sebagai sejarawan sosial dan budaya yang melihat tulisan sejarah sebagai latihan seorang intervensionis mengenai perbedaan pendapat. Sejarawan semacam ini umumnya dilakukan oleh sejarawan sayap kiri seperti E.P Thompson, Philip Foner,Christopher Hill dan lainnya. Pada saat ini disadari bahwa sejarah merupakan cara untuk mengkonstruksi dan menulis komitmen politik terhadap kaum yang 
termarjinal. Pada tahun 1970an sejarawan menyoroti cara kerja sejarawan dalam menarasikan cerita yang sesungguhnya merupakan hasil pemahaman mereka dari narasi lainnya. Perhatian terhadap cara kerja sejarawan ini pertama kali dikemukakan oleh Lawrence Stone pada 1979 dalam artikelnya berjudul "The Revival of Narrative", yang menganjurkan sejarawan untuk kembali pada penulisan sejarah naratif.Sejak akhir 1970an kesadaran peran besar tulisan dalam menghasilkan teks sehingga teks lebih dianggap merupakan representasi dari masa lalu daripada sebuah akses kepada realitas masa lalu yang objektif.Hal ini merupakan landasan dari sejarah dekonstruksi.

\section{Historiografi Indonesia Setelah Kemerdekaan}

Setelah kemerdekaan Indonesia,
muncul pemikiran di kalangan ilmuwan dan sejarawan Indonesia untuk menempatkan Indonesia sebagai pusat dari perkembangan sejarah atau Indonesiasentris untuk mengakhiri dominasi penulisan sejarah kolonial dan juga untuk memperkuat identitas keindonesiaan yang amat dibutuhkan pada saat itu dalam rangka nation building. Usaha penulisan sejarah Indonesia yang bernuansa Indonesiasentris pun dimulai sejak saat itu. Muhammad Yamin menisbahkan asal-usul Indonesia kepada Majapahit yang berpusat di Jawa karena dianggap daerah kekuasaannya hampir sama dengan wilayah negara nasional Indonesia. Muhammad Hatta, Takdir Alisyahbana, dan tokoh-tokoh dari luar Jawa menentang pendapat Muhammad Yamin tersebut.Roeslan Abdulgani mengusulkan agar sejarah Indonesia mengikuti doktrin Marxis yang menunjukkan antitesis antara kekuatan terang dan gelap, sementara Hatta menyarankan agar penulisan sejarah nasional bertujuan mewujudkan manusia Pancasila. Armijn Pane menulis sejarah dengan menempatkan Indonesia dalam jaringan perdagangan di Asia Tenggara. Sementara itu, tokoh Islam Hamka menulis sejarah Islam Indonesia yang dikatakannya telah ada di Nusantara sejak abad ke-8 yang berarti menepis anggapan bahwa Majapahit telah lebih dahulu ada sebelum Islam.

Pertentangan dan perbedaan pendapat di antara ilmuwan, sejarawan dan politisi dalam merumuskan bagaimana seharusnya sejarah nasional Indonesia ditulis mengakibatkan meskipun telah diselenggarakannya Kongres Sejarah Nasional I di Yogyakarta tetap tidak dapat menghasilkan suatu sejarah nasional yang resmi. Kongres itu sendiri lebih banyak membicarakan hal-hal filosofis atau teoretis sehingga meskipun menurut Kartodirdjo (2014:39) kongres tersebut berhasil memberikan saran-saran, pengertian - pengertian serta pandangan-pandangan mengenai pendekatan baru dalam sejarah Indonesia tetapi perkembangan tersebut baru pada tataran teori daripada praktiknya. Maka buku sejarah yang dipakai di sekolahsekolah pun merupakan buku sejarah yang ditulis oleh Sanusi Pane pada masa pendudukan Jepang. Buku sejarah semacam ini memandang penulisan sejarah Indonesiasentris adalah kebalikan dari penulisan sejarah kolonial, sehingga apa yang dianggap musuh pada sejarah kolonial menjadi pahlawan dan sebaliknya.

Padamasa OrdeLama, historiografi Indonesia dipengaruhi oleh politik yang memanas. Ide Soekarno bahwa "Revolusi belum Selesai "ingin diejawantahkan juga dalam penulisan sejarah Indonesia. Terbit buku Sejarah Pergerakan Nasional (1908-1964) Berdasarkan Kuliah-Kuliah 
Sedjarah Pergerakan Nasional Kursus Kader Revolusi, Angkatan Dwikora.Buku ini dibuat oleh Tim Pembantu Sejarah Pergerakan Nasional, Pengurus Besar Front Nasional yang dipimpin oleh Ali Sastroamidjojo yang dikoordinatori oleh Anwar Sanusi yang berasal dari PKI. Ditunjuknya Anwar Sanusi dari PKI semakin menggelisahkan pihak yang berseberangan yaitu militer. Jenderal Nasution yang memang telah lama menaruh perhatian pada sejarah, menilai perlu melakukan hal yang dilakukan oleh PKI.Nasution pun membentuk tim yang anggotanya merupakan dosen-dosen sejarah Universitas Indonesia antara lain yang paling terkemuka adalah Nugroho Notosusanto. Tidak cukup dengan itu, pada tahun 1964, Nasution meningkatkan Biro Chusus Sejarah Staf Angkatan Bersenjata menjadi Pusat Sejarah ABRI.

Pada masa Orde Baru, historiografi Indonesia sebenarnya masih mengikuti pola yang diterapkan rezim sebelumnya yang sentralistis dan eskatologis yang melihat masa keemasan pada masa prakolonial yang dilanjutkan oleh masa kolonial yang dianggap sebagai masa kegelapan. Masa kegelapan diakhiri dengan kebangkitan nasional yang mengantarkan bangsa Indonesia pada kemerdekaan. Perbedaan penulisan sejarah dengan masa sebelumnya adalah rezim Orde Baru memandang dirinya sebagai akhir sejarah yang menyelamatkan bangsa Indonesia dari kehancuran. Pada masa Orde Baru ini buku sejarah nasional berhasil diselesaikan terdiri dari enam jilid yang meliputi periode prasejarah hingga Orde Baru.Dari keenam jilid, jilid terakhir merupakan bagian yang terpenting bagi Orde Baru karena menceritakan bagaimana peran Soeharto menyelamatkan negara dan selanjutnya membangun sebuah zaman baru yang stabil dan fokus pada pembangunan. Pada jilid keenam ini juga ditekankan peran penting militer dalam melindungi kedaulatan nasional.

Setelah Orde Baru runtuh pada 1998, sejarah sentralistis terutama yang berkaitan dengan Orde Baru yang telah mapan selama 30 tahun tiba-tiba digugat kebenarannya. Peristiwa sejarah yang mengangkat Soeharto dan Orde Baru seperti Serangan Umum 1 Maret 1949, Gerakan 30 September 1965, Surat Perintah 11 Maret dan peran militer yang besar mendapat sorotan dan memicu perdebatan di berbagai kalangan masyarakat.Maka muncul berbagai buku sejarah yang menulis berbagai topik yang pada Orde Baru tidak mungkin diizinkan terutama yang berkaitan dengan komunisme.

\section{Historiografi Indonesiasentris Sebagai Sumber Pembelajaran Sejarah}

Telah disinggung bahwa pada Kongres Sejarah Nasional I di Yogyakarta tahun 1957 lebih menekankan pada aspek-aspek tujuan filosofis dan teoretis mengenai bagaimana sejarah nasional Indonesia harus ditulis. Pembahasanpembahasan yang bersifat filosofis tersebut pada akhirnya mendorong sejarah pada sejarah spekulatif yang berarti penulisan sejarah tidak didasarkan pada akumulasi pengetahuan faktual. Meskipun ilmu sejarah mengalami perkembangan yang pesat pada paruh kedua abad ke-20, tampaknya tidak banyak berpengaruh pada historiografi Indonesia paling tidak hingga periode Orde Baru.

Sejarawan Sartono Kartodirdjo yang ditunjuk sebagai salah seorang editor penulisan sejarah nasional Indonesia sejak tahun 1970an bahkan tidak dapat meyakinkan tim editor lainnya terutama Nugroho Notosusanto untuk menggunakan berbagai bidang 
ilmu dan perspektif dalam penulisan sejarah nasional. Menurut Kartodirdjo (2014:39), pembangunan nasion adalah sebuah proses budaya dan asal-usul pembentukan nasion mendahului negara kolonial maka untuk memahaminya perlu dipahami terlebih dahulu interaksi antara sejarah lokal dan proses di tingkat nasional. Tidak memperoleh dukungan, ia pun mengundurkan diri dari editor penulisan sejarah nasional pada 1984.

Setelah runtuhnya Orde Baru, muncul gugatan terhadap sejarah terutama yang berkaitan dengan Serangan Umum 1 Maret 1949, Gerakan 30 September 1965 dan Surat Perintah 11 Maret 1966.Muncul berbagai buku yang dikatakan meluruskan sejarah sehingga menimbulkan berbagai perdebatan di kalangan masyarakat. Pihak yang paling mendapat tantangan langsung tentu saja adalah guru sejarah. Untuk meredakan keresahan masyarakat mengenai pelajaran sejarah, maka Menteri Pendidikan Yuwono Sudarsono pun harus memerintahkan suplemen pada kurikulum sejarah. Pada suplemen kurikulum tersebut, peran Soeharto yang dibesar-besarkan pada masa Orde Baru diturunkan dalam Serangan Umum 1 Maret 1949 dan pada seputar dikeluarkannya Surat Perintah 11 Maret 1966.

Pelajaran sejarah sejak suplemen kurikulum 1999 dikeluarkan semakin mengecilkan Orde Baru. Pada Kurikulum 2004, pelajaran sejarah berusaha memberikan porsi yang lebih besar kepada sejarah daerah. Belum lama diterapkan kurikulum sejarah 2004 ini mendapat tentangan karena tidak menyebut PKI pada peristiwa $G 30 \mathrm{~S}$ sehingga menjadi G 30 S/PKI.Polemik di dalam masyarakat membuat kurikulum sejarah 2004 dilarang dan pelajaran sejarah pun kembali memakai kurikulum sebelumnya.
Terobosan baru terjadi pada Kurikulum Sejarah 2013 karena pelajaran sejarah tidak hanya mendapat porsi jam tatap muka lebih banyak tapi juga diberikan sebagai pelajaran inti yaitu pelajaran sejarah Indonesia dan sebagai pelajaran pilihan yaitu sejarah.

Kurikulum 2013 pada dasarnya ingin menegaskan bahwa pembelajaran berpusat kepada siswa (student centered) dan pendekatan saintifik dalam proses pembelajaran. Dengan demikian guru diharapkan lebih menjadi fasilitator dalam pembelajaran dan memberi kesempatan bagi siswa untuk lebih aktif.

Dengan kurikulum 2013 ini sebenarnya pelajaran dapat dikembangkan menjadi pelajaran yang sangat menarik bagi siswa karena melalui pendekatan saintifik dapat menemukan sendiri berbagai sumber yang memberikan pemahaman terhadap suatu peristiwa. Pada kurikulum sebelumnya memang guru telah diberikan kesempatan untuk mengembangkan sendiri kurikulum dan metode pengajaran tetapi belum optimal dilakukan karena memang jam pelajaran sejarah hanya berkisar 1-2 jam setiap minggunya.Sekarang, dengan alokasi jam yang lebih banyak untuk pelajaran sejarah Indonesia dan sejarah tentunya guru sejarah memiliki kesempatan untuk mendesain pembelajaran sejarah yang memungkinkan siswa mengeksplorasi lebih jauh lagi mengenai topik-topik sejarah.

Dengan metode saintifik, siswa seharusnya tidak lagi mengandalkan buku teks sebagai satu-satunya sumber tetapi didorong untuk memakai sumber-sumber lain seperti arsip dan dokumen termasuk sumber historiografi alternatif yang sekarang semakin banyak jumlahnya. Penggunaan sumber-sumber selain buku 
teksini menjadi amat penting jika dikaitkan dengan topik-topik kontroversial seperti Peristiwa Serangan Umum 1 Maret 1949, 30 September 1965, atau Surat Perintah 11 Maret 1966.

Melaksanakan pembelajaran sejarah seperti yang telah dijelaskan di atas, tentu saja tidak mudah. Guru sejarah harus merupakan orang yang berlakang pendidikan sejarah sehingga ia merupakan orang yang dibekali dengan ilmu pedagogik dan juga familiar dengan perkembangan historiografi dan perkembangan ilmu sejarah itu sendiri. Guru yang kompeten semacam itu akan mampu mengarahkan siswa-siswanya termasuk dalam memperkenalkan historiografi alternatif sehingga siswa tidak dibingungkan lagi dalam menghadapi kontroversi dalam penulisan sejarah. Justru adanya kontroversi dalam penulisan sejarah dapat dijadikan kesempatan oleh guru untuk mengembangkan daya pikir kritis siswa.

\section{KESIMPULAN}

Pembentukan identitas bangsa Indonesia merupakan isu penting yang paling mengemuka setelah kemerdekaan Indonesia 17 Agustus 1945.Muncul pemikiran untuk menempatkan Indonesia sebagai subjek dalam sejarah Indonesia atau dikenal sebagai Indonesiasentris untuk menggantikan sejarah kolonial. Akan tetapi terjadi perbedaan pendapat diantara ilmuwan, sejarawan dan juga pemimpin Indonesia mengenai apa dan bagaimana sejarah nasional Indonesia itu. Kongres Sejarah Nasional 1957 juga tidak sepenuhnya dapat merumuskan secara kongkrit mengenai hal tersebut. Kongres pada akhirnya terjebak pada isu-isu filosofis dan teoritis sehingga historiografi Indonesia seolah-olah melupakan sisi ilmiah dari sejarah. Situasi ini bertahan paling tidak hingga masa Orde Baru.

Setelah Orde Baru terjadi dekonstruksi sejarah. Sejarah nasional yang telah mapan selama 30 tahun dipertanyakan kembali kebenarannya. Pelajaran sejarah pun menjadi titik perhatian masyarakat.Peran guru sejarah menjadi krusial dalam menjawab kegelisahan publik mengenai sejarah.

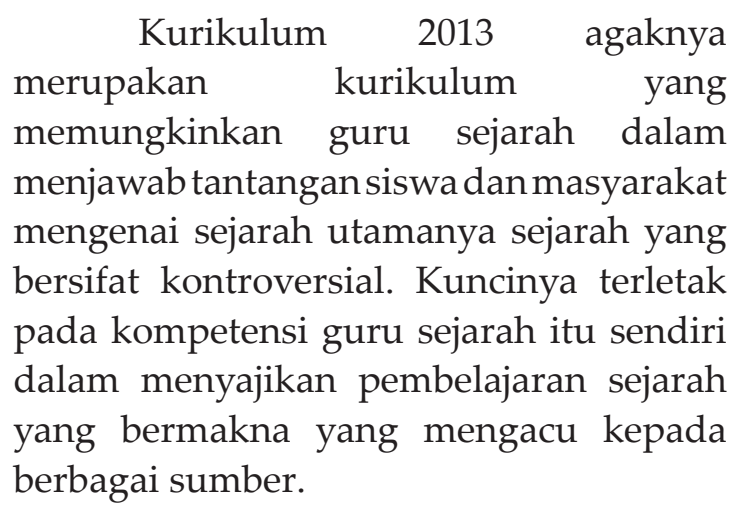

\section{Daftar Pustaka}

Abdullah, Taufik dan Abdurrahman Surjomihardjo (ed). Ilmu Sejarah dan Historiografi Arah dan Perspektif, Jakarta:Gramedia, 1985

Collingwood, R.G.Idea Sejarah terjemahan Muhd.Yusof Ibrahim, Kuala Lumpur:Percetakan Dewan Bahasa dan Pustaka, 1985

Kartodirdjo, Sartono, Pemikiran dan Perkembangan Historiografi Indonesia, Yogyakarta:Penerbit Ombak, 2014

Kochar, S. S., Teaching of History, Jakarta:Gramedia, 2010

Munslow, Alun. Deconstructing History, London:Routledge, 1997

Nordholt Henk Schulte, Bambang Purwanto, Ratna Saptari (Ed), Memikir Ulang Historiografi Indonesia dalam Perspektif Baru Penulisan Sejarah Indonesia, Jakarta:Penerbit Obor, 2008 
Rowse,A.L. Apa Guna Sejarah terjemahan Winda Primasari, Depok:Komunitas Bambu,2014

Tucker, Aviezer (ed), A Companion to The History and Historiography, West Sussex:Blackwell Publishing, 2009

Zed, Mestika.Penelitian Kepustakaan, Jakarta:Obor, 2008. 


\title{
Strategi Pengelolaan Pembelajaran Isu Materi Sejarah "Serupa" dan Sejarah Kontroversial
}

\author{
Oleh : Djunaedi \\ Pendidikan Sejarah PPS UNJ
}

\begin{abstract}
The purpose of this writing is to seek for the solution in the teacher's "problem" in managing Indonesian History as a regular subject and History Teaching as a special subject in accordance with 2013 Currriculum. That is because not only that two subjects contain the "same" scope of subject's material, but also because those contain controversial history material substance.

Based on the difference between the purpose of each subject, those are therefore offering the correct solution, which are the strategies in managing the "same" subject's material history substance teaching based on Constructivistic-Colaborative

By using those two strategies, not only that those solve the teacher's "problem" in implementing those two subjects, but also exploring student's competence in accordance with each learning objectives
\end{abstract}

Key words: Indonesia History Teaching and History

\begin{abstract}
Abstrak
Tujuan artikel ini adalah menemukan solusi atas "kegalauan" guru dalam mengelola pembelajaran Sejarah Indonesia sebagai mata pelajaran wajib dan pembelajaran Sejarah sebagai mata pelajaran peminatan sesuai Kurikulum 2013. Hal itu disebabkan ke dua mata pelajaran itu tidak saja memuat ruang lingkup materi pelajaran "serupa", tetapi juga mengandung substansi materi sejarah kontroversial.

Berlandaskan kepada adanya perbedaan tujuan pembelajaran masing-masing mata pelajaran, maka ditawarkan solusi yang dianggap tepat, yakni strategi pengelolaan pembelajaran ruang lingkup materi pelajaran "serupa" berbasis nilai dan strategi pengelolaan pembelajaran substansi materi sejarah kontroversial berbasis konstruktivistik-kolaboratif.

Dengan menggunakan kedua strategi pengelolaan pembelajaran itu, tidak hanya mampu mengatasi "kegalauan" guru dalam mengimplementasikan kedua mata pelajaran, melainkan juga dapat mengeksplor kompetensi siswa sesuai dengan tujuan pembelajaran masing-masing.
\end{abstract}

Kata Kunci: Pembelajaran Sejarah Indonesia dan Sejarah, strategi pembelajaran nilai dan berbasis konstruktivistik-kolaboratif

\section{PENDAHULUAN}

Perubahan kurikulum merupakan keniscayaan. Dimanapun di dunia, tidak ada kurikulum yang tetap dipertahankan dalam waktu yang sangat panjang. Demikian halnya dengan kurikulum 2013 yang diberlakukan oleh pemerintah melalui surat edaran Kementerian Pendidikan dan Kebudayaan (Kemendikbud) Nomor 156928/MPK.A/KR/ 2013 tanggal 8 November 2013 merupakan sesuatu yang "biasa saja" atau menjadi kelaziman sesuai dengan kebutuhan internal bangsa dan tuntutan eksternal dunia global. 
Terbitnya kurikulum 2013 yang dinyatakan sebagai penyempurna kurikulum sebelumnya (kurikulum 2006) mendapat respon yang senasib dengan kurikulum-kurikulum sebelumnya, yakni ada yang pro dan kontra terhadap pemberlakuannya. Bagi yang pro memandang kurikulum 2013 merupakan kurikulum yang paling progresif dibandingkan kurikulum-kurikulum sebelumnya. Hal itu diukur dari adanya muatan pendekatan pembelajaran saintifik dan penilaian otentik yang menjadi karakteristik khasnya. Sementara bagi yang kontra menganggap kurikulum 2013 adalah kurikulum yang tidak realistis karena sulit untuk diimplementasikan. Anggapan itu muncul karena berbagai faktor, mulai dari pendeknya waktu sosialisasi sehingga terkesan ketidaksiapan pemerintah untuk menyelenggarakannya sampai rumit dan kompleksnya persoalan yang ditimbulkan ketika sekolah atau guru (akan) mengimplementasikannya.

Hasil penelitian Djunaidi (2014), meskipun terbatas pada guru-guru pelajaran sejarah SLTA di DKI Jakarta, setidaknya dapat mewakili gambaran pro dan kontra tersebut di atas. Dari 19 guru yang menjadi responden penelitian, terdapat $66,57 \%$ yang kontra dan hanya 33 , $43 \%$ pro atau setuju terhadap implemntasi kurikulum 2013. Dua alasan utama yang dikemukakan oleh kelompok guru yang kontra, yakni: 1) Persiapan implementasi Kurikulum 2013 ini dianggap kurang matang, hal ini antara lain bisa ditujukkan mulai dari waktu sosialisasinya yang mepet tidak memadai hingga implementasi kompetensi instruktur/nara sumber yang dipertanyakan karena hanya melakukan ceramah satu arah. Tuntutan Kurikulum 2013 adalah mengubah paradigma (mindset) mengajar guru menjadi lebih aktif atau sebagai fasilitator dan motivator, sampai belum tersedianya buku sejarah peminatan untuk siswa; dan 2) Desainnya dianggap terlalu rumit, mulai mulai materi pelajarannya yang tumpang tindih di kelas wajib dengan kelas peminatan seperti pada kasus mata pelajaran pelajaran Sejarah Indonesia dengan mata pelajaran Sejarah sampai sangat rumitnya sistem penilaiannya, misalnya jenis instrument penilaiannya sangat bervariasi untuk mengukur semua aspek kompetensi siswa, penilaiannya dilakukan baik penilaian hasil maupun proses. Sementara jumlah siswa atau kelas yang harus dinilai relative banyak. Oleh karena itu untuk melaksanakannya dengan tepat, perlu waktu dan tenaga ekstra guru. Diantara mereka yang kontra terhadapimplementasi Kurikulum 2013 menyebutnya dengan singkatan "Kur-Ti-Las" alias Kurikulum Tidak Jelas.

Sementara bagi kelompok guru yang pro terhadap implementasi Kurikulum 2013 bersikap optimis, bahwa: 1) model pendekatan dan penilaian pembelajaran dalam Kurikulum 2013 dianggap sangat sesuai dengan tujuan pembelajaran sejarah, yakni selain memberi dan menilai wawasan pengetahuan siswa tentang peristiwa sejarah masa lalu, mengekslpor dan menilai kemampuan keterampilan siswa dalam melakukan tugas penelitian (sederhana) sejarah, juga menumbuhkan dan menilai sikap nasionalisme siswa; 2) Pendekatan pembelajarannya yang saintifik sesuai dengan prinsip pembelajaran modern Student Centered Learning (SCL). Dengan model pembelajaran seperti ini tidak saja menjadikan siswa aktif, juga mandiri dalam mendalami pelajaran; 3) Penilaian otentiknya pun dianggap dapat mempasilitasi penilaian yang relative lebih objektif dan konprehensif karena dilakukan baik saat dan sesudah pembelajaran berlangsung, mencakup semua aspek 
kompetensi (sikap, pengetahuan dan keterampilan), serta didukung oleh bukti fisiknya; 4) Dengan demikian, melalui implementasi Kurikulum 2013 yang tepat, maka harapan lebih terbuka untuk melahirkan siswa yang kreatif dan inovatif, sehingga memiliki kemampuan daya saing tinggi dan berkontribusi pada kehidupan masyarakat.

Pro dan kontra terhadap implementasi Kurikulum 2013 telah mendorong Anis Baswedan, Menteri Kebudayaan, Pendidikan Dasar dan Menengah menerbitkan Surat Edaran No. 179342/MPK/KR/2014 tertanggal 5 Desember 2014 yang menginstruksikan langsung kepada seluruh kepala sekolah di Indonesia untuk menghentikan pelaksanaan Kurikulum 2013 di sekolahsekolah yang baru menerapkannya satu semester pada Tahun Pelajaran 2014/2015 dan kembali menggunakan kurikulum 2006 serta mengijinkan untuk meneruskan bagi sekolah-sekolah yang telah melaksanakannya tiga semester dan menyatakan siap untuk terus melaksanakannya.

Ternyata surat edaran menteri itu tidak serta merta mampu menghentikan polemik, bahkan ada diantara para pakar atau pengamat menyikapi instruksi itu sebagai kebijakan yang "langka" terjadi, baik di dalam negeri maupun di dunia. Pemberlakuan 2 kurikulum dalam satu masa menunjukkan ketidaksiapan pemerintah dan dianggap sebagai "kekacauan" penyelenggaraan sistem pendidikan nasional .

Terlepas dari polemik itu, penulis sependapat dengan Susanto Zuhdi (2014:1) Sejarahwan pemerhati pendidikan sejarah yang menyatakan, bahwa dengan adanya inovasi pada pendidikan sejarah di SMA/MA menjadi 2 (dua) mata pelajaran, yakni Sejarah Indonesia dan Sejarah berarti Kurikulum 2013 telah menempatkan kembali pendidikan sejarah pada posisinya yang sangat penting dan strategis dalam kehidupan berbangsa dan bernegara. Dengan kata lain, Kurikulum 2013 telah menempatkan pendidikan sejarah tidak hanya sebatas alat politik untuk penanaman nila-nilai kebangsaan, melainkan juga sebagai sarana akademik pengembangan berpikir ilmiah siswa.

Oleh karena itu, tulisan ini tidak ingin ikut larut pada polemik implementasi Kurikulum 2013, tetapi ingin bersikap realistis sebagaimana disampaikan Susanto Zuhdi di atas. Apalagi sampai saat ini Kurikulum 2013 masih berlaku bersamasama dengan Kurikulum 2006. Artinya, tulisan ini akan memberi sumbang pikir khususnya untuk bapak ibu guru yang saat ini sedang dan akan mengampu mata pelajaran sejarah di tingkat SMA/MA. Sumbang pikir itu terkait dalam rangka strategi pengelolaan pembelajan Sejarah Indonesia sebagai salah satu Mata Pelajaran Wajib dan pembelajaran Sejarah sebagai salah satu Mata Pelajaran Peminatan.

Sebagaimana sepintas dinyatakan di atas, bahwa perlunya sumbang pikir mengenai strategi pengelolaan pembelajaran sejarah di SMA/MA ini terkait karena adanya 2 (dua) isu pokok, yakni: 1) terdapatnya ruang lingkup materi yang "serupa" pada mata pelajaran Sejarah Indonesia dan mata pelajaran Sejarah yang dianggap sebagai tumpang tindih; dan 2) terkandungnya substansi materi sejarah kontroversial yang urgensi atau kegunaannya bagi siswa tingkat SMA/MA masih dipertanyakan.

Selaras dengan isu di atas dan maksud penulisan artikel ini, maka permasalahan yang akan dideskripsikan ada 2 (dua), yakni: 
- Bagaimanakah strategi pengelolaan pembelajaran ruang lingkup materi sejarah "serupa" ? dan

- Bagaimanakah strategi pengelolaan pembelajaran substansi materi sejarah kontroversial?

\section{METODE PENELITIAN}

\section{Hakikat Strategi Pengelolaan Pembelajaran}

J.R. David pada 1976 (Sanjaya, 2008: 126) mendefinisikan strategi pengelolaan pembelajaran sebagai: "a plan, method, or series of activities designed to achieves a particular educational goal." Itu artinya, strategi pengelolaan pembelajaran terkait dengan rencana tindakan, termasuk penggunaan metode dan pemanfaatan berbagai sumber daya dalam pembelajaran, seperti materi pelajaran (subject matters) dan prosedur atauy metode pembelajaran dalam rangka untuk mencapai tujuan pembelajaran tertentu. Dick and Carey pada 1985 (Sanjaya, 2008:126) juga menyebutkan bahwa strategi pengelolaan pembelajaran itu adalah upaya pengaturan suatu set materi dan prosedur pembelajaran yang digunakan secara bersama-sama untuk menimbulkan hasil belajar pada siswa. Dari definisi 2 (dua) tokoh pendidikan tersebut tentang strategi pengelolaan pembelajaran, maka dapat disimak adanya 2 (dua) komponen terkait yang perlu dikelola, yakni materi pelajaran dan prosedur atau metode pembelajaran.

Menurut National Center for Vocational Education Research Ltd (Anonim:2014:1) ada tiga pengertian materi pelajaran, yaitu: 1) merupakan informasi, alat dan teks yang diperlukan guru/ instruktur untuk menyusun perencanaan dan implementasi pembelajaran; 2) segala bentuk bahan yang digunakan untuk membantu guru/instruktur dalam kegiatan belajar mengajar di kelas; 3) seperangkat substansi pembelajaran yang disusun secara sistematis, menampilkan sosok yang utuh dari kompetensi yang akan dikuasai siswa dalam proses pembelajaran.

Materi pelajaran menempati posisi yang sangat penting dari keseluruhan kurikulum dan proses pembelajaran, yang harus dipersiapkan agar pelaksanaan pembelajaran dapat mencapai tujuan yang ditetapkan. Oleh karena itu, materi yang ditentukan untuk kegiatan pembelajaran haruslah materi yang benarbenar menunjang tercapainya kompetensi dan indicator yang ditetapkan. Dengan kata lain, agar materi pelajaran sesuai dengan tujuan pembelajaran perlu strategi pengelolaan pembelajaran yang tepat.

Kemudian prosedur pembelajaran atau sinonim dengan metode pembelajaran diartikan sebagai cara yang digunakan untuk melaksanakan strategi pengelolaan pembelajaran (Eggen dan Kauchak, 2012: 6). Jika strategi pengeloaan pembelajaran menunjuk a plan of opration achieving something, maka metode pembelajaran adalah a way in achieving something.

Kemp pada 1955 (Sanjaya, 2008: 126) menegaskan, bahwa strategi pengelolaan pembelajaran harus senantiasa dilakukan guru agar tujuan pembelajaran dapat dicapai secara efektif dan efisien. Dalam konteks ini, hal yang perlu dipertimbangkan guru dalam mengelola materi pelajaran dan metode pembelajaran menurut Sudjana (2002: 75 ; Agung, 2013: 113) adalah: 1) harus sesuai dengan tujuan pembelajaran. Tugas guru adalah memilih materi pelajaran dan metode pembelajaran yang tepat.; 2) urgen, yakni penting untuk siswa; 3) tuntutan kurikulum, yakni secara minimal materi pelajaran dan metode pembelajaran yang dipilih dan digunakan sesuai desain kurikulum; dan 4) nilai 
kegunaan, yakni materi itu mempunyai manfaat bagi siswa.

Dari paparan di atas dapat disimpulkan, bahwa yang dimaksud dengan strategi pengelolaan pembelajaran adalah upaya-upaya tertentu dalam menyiapkan perangkat pembelajaran, termasuk materi pelajaran dan metode pembelajaran dalam rangka mencapai tujuan pembelajaran.

\section{Hakikat Mata Pelajaran Wajib dan Peminatan}

Kurikulum 2013 memberikan kesempatan kepada peserta didik untuk mengembangkan kemampuan, bakat dan minat secara lebih luas dan terbuka sesuai dengan prinsip perbedaan individu. Ini memungkinkan peserta didik berkembang over achievement, yakni peserta didik yang memiliki tingkat penguasaan di atas standar yang telah ditentukan baik dalam pengetahuan, sikap, maupunketerampilan. Untuk itu struktur Kurikulum 2013 pada SMA/MA menyediakan mata pelajaran wajib diikuti oleh seluruh peserta didik di satu satuan pendidikan pada setiap satuan dan jenjang pendidikan dan mata pelajaran pilihan yang diikuti oleh peserta didik sesuai dengan pilihannya. Mata pelajaran pilihan juga diberikan pada peserta didik usia pendidikan menengah (15-18 tahun) yang terdiri atas pilihan akademik (SMA/ MA) dan pilihan vokasi (SMK/MAK). Mata pelajaran pilihan ini memberi corak kepada fungsi satuan pendidikan dan di dalamnya terdapat pilihan sesuai dengan minat peserta didik.

Sementara itu, Kurikulum 2013 juga lebih sensitif dan respek terhadap perbedaan kemampuan dan kecepatan belajar peserta didik, dan untuk SMA/ MA dan SMK memberikan peluang yang lebih terbuka kepada peserta didik untuk memilih mata pelajaran yang diminati, mendalami materi mata pelajaran dan mengembangkan berbagai potensi yang dimilikinya secara fleksibel sesuai dengan kemampuan dasar umum (kecerdasan), bakat, minat dan karakteristik kepribadian tanpa dibatasi dengan sekat-sekat penjurusan yang terlalu kaku (Anonim, 2013a: 3-4).

\section{Hakikat Ruang Lingkup Materi Pelajaran "Serupa"}

Ruang lingkup materi pelajaran adalah batasan dari seperangkat substansi pembelajaran yang disusun secara sistematis, menampilkan sosok yang utuh dari kompetensi yang akan dikuasai siswa dalam proses pembelajaran (Anonim: 2014a: 1). Dalam konteks tulisan ini, yang dimaksud dengan ruang lingkup materi pelajaran "serupa" adalah kesamaan ruang lingkup materi pelajaran Sejarah Indonesia dengan mata pelajaran Sejarah sekaligus perbedaan pada substansi pengembanganya sesuai tujuan masingmasing mata pelajaran.

\section{Hakikat Materi Sejarah Kontroversial}

Sejarah kontroversial menurut Nirtzche (Suud,1994: 8) adalah kisah sejarah (historiografi) yang mudah diterima oleh seseorang atau kelompok tetapi juga mudah ditolak oleh sesorang atau kelompok lain. Pendapat ini diperkuat oleh Abu Su'ud (1994: 8), bahwa peristiwa kontroversial secara langsung menyebabkan orang atau kelompok berbeda pendapat karena adanya asosiasi perasaan orang atau kelompok orang dalam menanggapi fenomena yang ada, serta keterkaitan emosi dan kecenderungan orang memihak seseorang atau kelompok didasari pemikiran tertentu.

Pada hakikatnya menurut S.K. Kochhar (2008: 453-454), sejarah itu penuh dengan isu kontroversi. Kochhar 
menyatakan ada 2 (dua) jenis sejarah kontroversial, yang pertama berkaitan dengan fakta-fakta dan yang kedua berkaitan dengan signifikansi, relevansi dan interpretasi sekumpulan fakta. Sejarah kontroversial tidak hanya karena terjadinya multi tafsir dalam interpretasi, tetapi juga karena keterbatasan data sejarah sehingga menimbulkan polemik. Jadi bukan sesuatu yang asing kalau dalam tulisan sejarah akan muncul hal-hal yang cenderung bersifat kontroversial.

Kemudian Hamid Hasan 2012: 5-7) menegaskan pentingnya sejarah kontroversial bagi siswa dapat menjadi sarana efektif untuk: 1) biasa menghadapi perbedaan pendapat; 2) kajian keilmuan sejarah, yakni sejarah dikaji secara objektif berdasarkan sumber sejarah yang ditemukan, termasuk yang masih kontroversial; (3) persiapan memasuki perguruan tinggi bagi siswa yang berminat masuk program studi sejarah atau pendidikan sejarah.

Perlunya peristiwa kontroversi diberikan dalam kurikulum SMA diperkuat dengan hasil penelitian Pujiastuti (2004: 25) dan Hastuti (2009: 186189) yang relatif serupa, yakni: 1) siswa merasa adanya sesuatu yang baru dalam pembelajaran sejarah yang mengarah pada aspek afektif dan psikomotorik tidak hanya kognitif semata; 2) pemanfaatan sumber belajar isu sejarah kontroversial, akan sangat membantu siswa dalam meningkatkan kesadaran sejarahnya. Semakin banyak permasalahan isu sejarah kontroversial yang didiskusikan dan dianalisis siswa, maka semakin terbuka peluang bagi siswa untuk meningkatkan kesadaran sejarahnya (kognitif, afektif dan kritis); 3) pemanfaatan sumber belajar isu sejarah kontroversial, selain siswa secara konsep memahami peristiwa sejarah, juga belajar untuk menyadari bahwa kebenaran mutlak bukan milik manusia, sementara perbedaan adalah hal yang pasti akan ditemui; 4) Pemanfaatan sumber belajar isu sejarah kontroversial tidak hanya sebagai upaya peningkatan pembelajaran sejarah tetapi juga pelajaran sejarah itu sendiri. Siswa jadi senang belajar sejarah karena termotivasi atau tertantang untuk aktif terlibat menemukan jawaban atas kontroversial tersebut.

Artikel ini ditulis dengan menggunakan metode kajian pustaka. Data yang digunakan sebagai sumber penulisan berupa dokumen kurikulum 2013 yang diterbitkan oleh Kementerian Pendidikan dan Kabudayaan RI, Surat Menteri Pendidikan dan Kebudayaan RI, laporan hasil penelitian, buku mata pelajaran sejarah Sekolah Menengah, dan beberapa buku dan artikel yang terkait dengan kajian.

\section{HAIL DAN PEMBAHASAN}

Untuk menjawab pertanyaan permasalahan, maka tulisan ini akan membahas tentang : 1). Pendidikan Sejarah dalam Kurikulum 2013; dan 2). strategi pengelolaan pembelajaran materi sejarah "serupa" dan 3). strategi pengelolaan pembelajaran materi sejarah kontroversial.

\section{Pendidikan Sejarah Pada Kurikulum 2013}

Pada bagian ini, yang penting untuk dideskripsikan adalah: 1) kedudukan pendidikan sejarah dalam struktur Kurikulum 2013; dan 2) Perbedaan tujuan dan ruang lingkup masing-masing mata pelajaran.

Dalam struktur kurikulum 2013, diantaranya terdapat mata pelajaran Sejarah Indonesia dan Mata Pelajaran Sejarah. Mata pelajaran Sejarah Indonesia 
sebagai mata pelajaran wajib 2 jam bagi seluruh siswa SMA/MAN/SMK kelas X, XI, dan XII. Sedangkan, mata pelajaran Sejarah sebagai mata pelajaran Peminatan Ilmu Pengetahuan Sosial (IPS) bagi siswa SMA/MA, yakni masing-masing 3 jam di kelas X dan 4 jam di kelas XI dan XII. Mata pelajaran Sejarah, bisa juga dipilih oleh siswa Lintas Minat dan/atau Pendalaman Minat dari kelompok Matematika dan Ilmu Pengetahuan Alam (MIPA) dan kelompok Ilmu Pengetahuan Bahasa dan Budaya (IPBB)( Anonim, 2013b: 3-4; Anonim, 2013c: 1101-1102;).

Dalam kurikulum 2013 (Anonim, 2013b: 3-4; lihat juga Hasan, 2012: 168) dinyatakan, bahwa ada 6 (enam) tujuan mata pelajaran Sejarah Indonesia, yakni sebagai berikut:

1. Mengembangkan rasa kebangsaan, cinta tanah air dan penghargaan terhadap hasil dan prestasi bangsa;

2. Membangun rasa kebangsaan, cinta tanah air, memahami masyarakat dan bangsa, serta menyadari keberlanjutan masa lalu dalam kehidupan masa kini, untuk membangun kehidupan masa depan yang lebih baik ;

3. Membangun kesadaran peserta didik tentang pentingnya konsep waktu dan tempat/ruangdalam rangka memahami perubahan dan keberlanjutan dalam kehidupan bermasyarakat dan berbangsa di indonesia;

4. Mengembangkan kemampuan berpikir historis (historical thinking) melalui kajian fakta dan peristiwa sejarah;

5. Menumbuhkan apresiasi dan penghargaan peserta didik terhadap peninggalan sejarah sebagai bukti peradaban bangsa indonesia di masa lampau;
6. Menumbuhkan kesadaran dalam diri peserta didik sebagai bagian dari bangsa indonesia yang memiliki rasa bangga sebagai bangsa, cinta tanah air, melahirkan empati dan perilaku toleran yang dapat diimplementasikan dalam berbagai bidang kehidupan masyarakat dan bangsa;

Berdasarkan tujuan tersebut, dikembangkan 13 ruang lingkup mata pelajaran Sejarah Indonesia (Anonim, 2013b: 4), yakni:

1. Prinsip dasar ilmu sejarah;

2. Praaksara;

3. Hindu-Buddha;

4. Kerajaan-kerajaan Islam;

5. Penjajahan bangsa Barat;

6. Pergerakan Nasional;

7. Proklamasi dan perjuangan mempertahankan kemerdekaan;

8. Demokrasi Liberal;

9. Demokrasi Terpimpin;

10. Orde Baru;

11. Reformasi;

12. Tokoh sejarah;

13. Peninggalan sejarah lokal

Tujuan mata pelajaran Sejarah juga ada 6 (enam) (Anonim, 2013c: 1102), yakni:

1. Membangun kemampuan peserta didik menggunakan konsep waktu, ruang, perubahan dan kesinambungan dalam berfikir kesejarahan;

2. Mengembangkan kemampuan berpikir sejarah (historical thinking), ketrampilan sejarah (historical skills), dan wawasan terhadap isu sejarah (historical issues), serta menerapkan kemampuan, ketrampilan dan 
wawasan tersebut dalam kehidupan masa kini;

3. Mengembangkan perilaku yang didasarkan pada nilai dan moral yang mencerminkan karakter diri, masyarakat dan bangsa;

4. Menanamkan sikap berorientasi kepada masa kini dan masa depan;

5. Memahami dan mampu menangani isu-isu kontroversial untuk mengkaji permasalahan yang terjadi di lingkungan masyarakatnya;

6. Mengembangkan pemahaman internasional dalam menelaah fenomena actual dan global;

Berdasarkan tujuan tersebut, dikembangkan juga 13 ruang lingkup mata pelajaran Sejarah (Anonim, 2013c: 1102-1103), sebagai berikut:

1. Prinsip dasar ilmu sejarah;

2. Peradaban awal masyarakat Dunia dan Indonesia;

3. Perkembangan negara - negara tradisional di Indonesia;

4. Indonesia pada Masa Penjajahan;

5. Revolusi besar dunia dan pengaruhnya;

6. Kebangkitan heroisme dan kebangsaan Indonesia;

7. Proklamasi dan perkembangan negara kebangsaan Indonesia;

8. Perjuangan mempertahankan kemerdekaan Indonesia;

9. Dunia pada Masa Perang Dingin dan perubahan poilitik global;

10. Indonesia pada Masa Demokrasi Liberal dan Demokrasi Terpimpin;

11. Indonesia pada Masa Orde Baru;

12. Indonesia pada Masa Reformasi;
13. Indonesia dan dunia pada Masa Revolusi Teknologi Informasi dan Komunikasi.

Pada hakikatnya tujuan kedua mata pelajaran tersebut sebagaimana umumnya pelajaran yang lain, meliputi 3 (tiga) ranah kompetensi, yakni pengetahuan (kognitive), sikap (affective), dan keterampilan (phsycomotoric) (Anderson, 2001: 26). Namun, adanya pengembangan pendidikan sejarah menjadi 2 (dua) mata pelajaran, maka berimplikasi pada penegasan tujuan dan ruang lingkup masing-masing mata pelajaran itu. Tujuan mata pelajaran Sejarah Indonesia lebih ditekankan sebagai alat pendidikan dalam rangka menumbuhkan kompetensi nilainilai kesejarahan bangsa pada peserta didik, yakni sikap nasionalisme dan jati diri bangsa. Sementara tujuan mata pelajaran Sejarah lebih ditekankan sebagai sarana pengembangan kompetensi keilmuan sejarah pada peserta didik, yakni berpikir historis dan berpikir kritis (Hasan, 2012: 168).

Pada sisi ruang lingkup, mata pelajaran Sejarah Indonesia dan mata pelajaran Sejarah memiliki materi pelajaran yang "serupa", selaian terdapat beberapa yang berbeda. Materi pelajaran yang "serupa", yakni mulai dari "Prinsip Dasar Ilmu Sejarah, Masa Pra Aksara Indonesia, sampai dengan Indonesia Masa Reformasi. Sedangkan materi pelajaran yang berbeda, yakni pada mata pelajaran Sejarah Indonesia secara spesifik mempelajari substansi Peninggalan Sejarah Lokal dan Tokoh Sejarah. Sementara substansi Sejarah Dunia dan Sejarah Masa Revolusi Teknologi Informasi dan Komunikasi hanya pada mata pelajaran Sejarah.

Namun demikian, yang perlu sangat dicermati adalah terjadinya kontinuitas pada ruang lingkup mata pelajaran Sejarah 
Indonesia, yakni: 1) Sejarah Nasional menjadi payung untuk mengenal bangsa, sedangkan Sejarah Lokal menjadi payung untuk mengenal masyarakat di sekitarnya; dan 2) kedua jenis materi sejarah itu merupakan peristiwa yang terkait satu dengan lainnya. Kejadian dalam peristiwa sejarah nasional diikuti dan diperkuat oleh gerak sejarah lokal. Sementara melalui mata pelajaran Sejarah siswa diajak untuk melihat keberlanjutan dan perubahan yang terjadi dalam masyarakat dan bangsa di dunia yang terkait dengan perkembangan sejarah Indonesia (Ibid., 118-126).

Ilustrasi perbedaan mata pelajaran Sejarah Indonesia dengan Sejarah digambar-kan, sebagai berikut:

\section{PEMBELAJARAN SEJARAH}

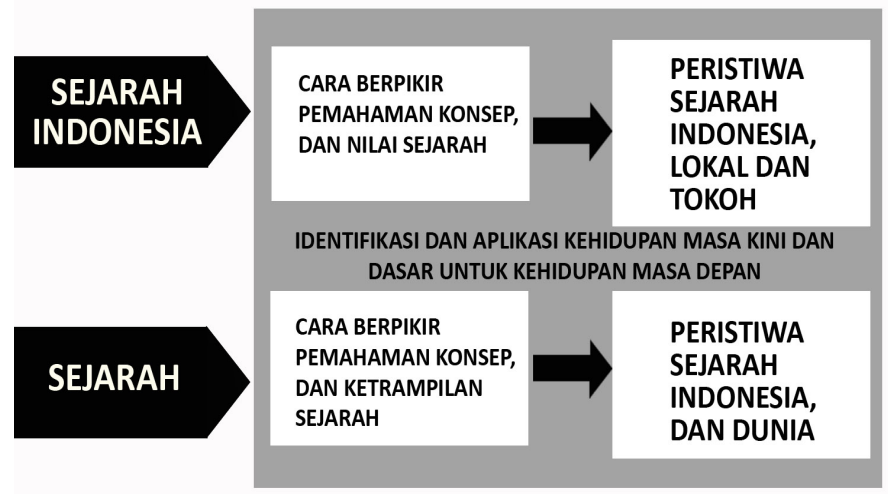

Strategi Pengelolaan Pembelajaran Ruang Lingkup Materi Pelajaran"Serupa"

Sebagaimana telah dinyatakan di atas, bahwa arti ruang lingkup mataeri "serupa" adalah kesamaan ruang lingkup materi pelajaran Sejarah Indonesia dengan mata pelajaran Sejarah, tetapi memiliki perbedaan pada substansi pengembanganya sesuai tujuan masing-masing mata pelajaran. Perbedaan inilah yang menjadi pusat strategi pengelolaannya. Jadi guru dalam konteks mata pelajaran Sejarah dapat mengembangkan ruang lingkup materi "serupa" berbasis nilai-nilai kesejarahan. Hamid Hasan (2012: 63-64) menemukan setidaknya terdapat 10 (sepuluh) nilai dalam Sejarah Indonesia, yakni: 1) Kepahlawanan; 2) Kepemimpinan; 3) Keteladanan; 4) Kebijakan; 5) Persatuan; 6) Nasionalisme; 7) Patriotisme; 8) Inspiratif; 9) Apresiasi; dan 10) Toleransi. Sementara itu, Tim Pengembang Kurikulum 2013 Direktorat Pembinaan SMA-Ditjen Pendidikan Menengah, Kemendikbud berdasarkan analisis Kompetensi Inti (KI-1 dan KI-2) sesuai Permendikbud Nomor 54 tahun 2013 untuk tingkat SMA (Anonim, 2014b: 25) berhasil mengembangkan nilai-nilai Sejarah Indonesia, sebagaimana tertulis dalam tabel berikut:

\begin{tabular}{|l|l|}
\hline Dimensi & Kualifikasi Kompetensi \\
\hline Sikap & Kemampuan siswa \\
meligius & $\begin{array}{l}\text { menghima, menghargai, } \\
\text { dan mengamali, menjalankan nilai-nillai } \\
\text { kesejarahan, seperti: jujur, } \\
\text { disiplin, tanggungjawab, } \\
\text { peduli, santun, percaya diri. }\end{array}$ \\
\hline Sikap Sosial & $\begin{array}{l}\text { Kemampuan siswa } \\
\text { menerima, menghargai, } \\
\\
\\
\text { menghayati, menjalankan } \\
\text { dan mengamalkan nilai- } \\
\text { nillai kesejarahan, } \\
\text { seperti: kepahlawanan, } \\
\text { kepemimpinan, keteladanan, } \\
\text { kebijakan, persatuan, } \\
\text { nasionalisme, patriotisme, } \\
\text { inspiratif, apresiasi, toleransi. }\end{array}$ \\
\hline
\end{tabular}

Nilai-nilai kesejarahan tersebut seyogyanya masih dapat dikembangkan lagi oleh guru dan siswa selama proses pembelajaran. Kemudian, strategi pengelolaan ruang lingkup materi sejarah berbasis nilai tersebut dapat disesuaikan dengan metode atau model pembelajaran yang digunakan guru. 
Contoh strategi pengelolaan pembelajaran mata pelajaran Sejarah Indonesia sebagai mata pelajaran Wajib. Misalnya materi "Sejarah Pendudukan Jepang di Indonesia". Model Pembelajaran yang digunakan Penemuan (Discovery Learning) atau Inkuiri (Inquiry Based Learning). Pada konteks ini guru akan menugaskan siswa untuk mengeksplor nilai-nilai spritual dan social dari peristiwa tersebut, misalnya pembentukan "Jawa Hokokai" (nilai kemandirian, dll), tragedi "Romusa" (nilai pengorbanan, dll), Perlawanan tentara PETA (nilai disiplin, keberanian, dll).

Sementara itu, Tim yang sama juga melakukan analisis KI-3 dan K4 dalam rangka mengembangkan nilai-nilai akademik bagi mata pelajaran Sejarah sebagai mata pelajaran Peminatan, sebagai berikut:

\begin{tabular}{|l|l|}
\hline Dimensi & Kualifikasi Kompetensi \\
\hline Pengetahuan & $\begin{array}{l}\text { Kemampuan siswa } \\
\text { menerapkan pengetahuan } \\
\text { faktual, konseptual, } \\
\text { prosedural, dan } \\
\text { metakognitif ilmu sejarah, } \\
\text { yakni prinsip dasar ilmu } \\
\text { sejarah, sejarah Indonesia, } \\
\text { sejarah lokal, sejarah tokoh, } \\
\text { dan sejarah dunia. }\end{array}$ \\
\hline Keterampilan & $\begin{array}{l}\text { Kemampuan siswa } \\
\text { menerapkan kemapuan } \\
\text { keterampilan ilmu } \\
\text { sejarahnya, seperti: } \\
\text { merawat peninggalan } \\
\text { sejarah, mendokumen- } \\
\text { tasikannya, membuat peta } \\
\text { sejarah, membuat replika } \\
\text { benda sejarah, melakukan } \\
\text { penelitian sejarah secara } \\
\text { sederhana, dan sebagainya. }\end{array}$ \\
\hline Pada \\
contoh materi yang serupa \\
pembelajaran yang sama seperti contoh di
\end{tabular}

atas, maka strategi pengembangan yang dapat dilakukan oleh guru pada mata pelajara Sejarah sebagai mata pelajaran Peminatan, yakni dengan menugaskan siswa untuk mengeksplor nilai-nilai pengetahuan dan keterampilan dari materi "Sejarah Pendudukan Jepang" tersebut. Upaya yang bisa dilakukan guru antara lain, dengan mengajak siswa untuk mengkaji berbagai pendapat atau analisa dari berbagai literatur atau bahan ajar tentang topik "Sejarah Pendudukan Jepang di Indonesia." Nilai yang mungkin dapat ditemukan siswa dari topik itu, misalnya masa pendudukan Jepang di Indonesia telah berdampak memecah hubungan sosial tradisional pada tingkat lokal serta menyiapkan kondisi bagi terciptanya latarbelakang revolusi nasional dan sosial pada tahun 1945-1949 (Aiko Kurasawa, 1988). Selanjutnya, meskipun masa pendudukan Jepang ini merupakan pengalaman berat dan pahit bagi kebanyakan orang Indonesia, tetapi ini merupakan masa peralihan dimana dalam beberapa hal gerakan nasionalis mendapat kemajuan (Ricklefs, 1981; Frederick, 1986), dan seterusnya.

\section{Strategi Pengelolaan Pembelajaran Substansi Materi Sejarah Kontroversial}

Sebagaimana telah juga dinyatakan di atas, selain guru mengelola materi sejarah "serupa", juga harus mengelola materi sejarah kontroversial yang banyak terkandung dalam peristiwa sejarah Indonesia. Rizem Aizid (2014) dalam bukunya telah menyajikan sebanyak 27 sejarah kontroversi Indonesia, mulai dari "kontroversi masuknya pengaruh Hindu-Buddha di Nusantara" sampai dengan "kontroversi naskah Pancasila". Sementara Asvi Warman Adam (2007) mengkaji sebanyak 20 topik sejarah konversi Indonesia yang terjadi selama seabad. 
Terkait strategi pengelolaan pembelajaran sejarah kontroversial ini, di atas telah dideskripsikan perlunya sejarah kontroversial bagi siswa. Tinggal yang perlu dilakukan adalah sikap bijak agar tidak menjadi kontraproduktif bagi siswa. Dalam konteks ini, penulis lebih sepakat, bahwa sejarah kontroversial hanya dikembangkan pada mata pelajaran Sejarah sebagai mata pelajaran Peminatan di kelas XII SMA/MA. Pertimbangannya bukan hanya secara psikologis siswa tersebut rata-rata sudah memiliki tingkat kematangan berpikir abstrak, seperti berpikir kritis dan analitis sebagaimana dinyatakan oleh penganut teori kognitif Erikson dan Jean Piaget (Sumantri, 2006:1315). Melainkan juga karena siswa tersebut berdasarkan konsep ideal Kurikulum 2013 akan diproyeksikan melanjutkan ke Perguruan Tinggi, Program Studi Sejarah atau Pendidikan Sejarah (Hasan, 2012: 5-7).

Persoalannya kini, bagaimanakah strategi pengeloaan pembelajaran sejarah kontroversial? Sebagai gambaran, relatif tidak terdapat perbedaan yang signifikan tentang pembelajaran sejarah kontroversial antara di sekolah dan di kampus. Jika pun ada perbedaan terletak pada sisi kedalaman pengkajiannya mengingat bobot waktu pembelajaran di sekolah yang lebih pendek dan standar kompetensi yang lebih rendah. Dengan perbedaan itu, tentunya pengkajian peristiwa kontroversi di kampus dapat lebih luas dan mendalam dibandingkan dengan di sekolah. Namun demikian dalam rangka strategi pengelolaan pembelajarannya, guru di sekolah lebih dapat bervariasi. Misalnya, bisa menggunakan metode bermain peran atau "lorong waktu".

Kemudian strategi pengelolaan pembelajaran kolaboratif (Utomo, 2011: 42). relatif tepat digunakan untuk mengkaji peristiwa kontrovesial. Strategi pembelajaran kolaboratif mengutamakan aktivitas peserta didik daripada aktivitas guru, ..., studi kasus, pemecahan masalah, diskusi panel, diskusi, brainstorming, dan simulasi. Dalam strategi ini, dapat juga dilakukan lewat metode bedah buku bersama penulisnya atau metode project seminar sejarah, dengan mengundang nara sumber sejarah, sehingga guru dan siswa pada saat yang sama dapat melakukan pembelajaran. Dalam strategi ini perlu menjadi perhatian, bahwa peranan guru yang utama adalah memberikan alternatifalternatif melalui aflikasi, bukti-bukti dan argumen-argumen. Tujuan utama strategi pengelolaan pembelajaran ini adalah untuk mengaktifkan siswa memperoleh informasi dengan cara-cara yang sangat mudah dipahami dan bermanfaat (Utomo, 2011: 255).

Melalui strategi pembelajaran kolaboratif, kajian sejarah kontroversial menjadi lebih menarik karena siswa tidak hanya melibatkan aspek kognisi semata, melainkan pelibatan mental emosionalnya. Hal ini sesuai dengan definisi konsep pembelajaran konstruktivistik, yakni sebagai pembelajaran yang menekankan pada peran aktif bersama peserta didik dalam membangun pemahaman dan menyusun informasi dari sumber pengetahuan yang tersedia dan sudah dikuasai. Dengan kata lain, pemanfaatan sejarah kontroversial melalui strategi pengeloaan pembelajaran konstrukttifkolaboratif dapat membuat siswa memiliki kemampuan melakukan analisisis dan interpretasi terhadap peristiwa sejarah kontroversi yang telah dipelajari.

Untuk mengukur tingkat keberhasilan strategi pembelajaran konstruktivistik-kolaboratif menurut Festinger (Bootzin, 1999: 314-317) dapat diamati dari sikap dan prilaku (attitude and behavior) siswa dalam merespon 
pembelajaran sejarah kontroversi, misalnya setuju atau tidak, mendukung atau menentang. Strategi Festingger ini dikenal dengan nama disonansi kognitif.

Strategi pengelolaan pembelajaran disonansi kognitif dari Festingger ini jika diterapkan dalam pembelajaran sejarah yang memanfaatkan peristiwa kontroversial dapat membuat siswa cenderung merubah sikap dan keyakinannya demi kepentingan yang lebih rasional. Termasuk pada siswa yang memilikiegotinggiuntukmempertahankan argumentasinya yang tidak rasional. Disonansi disini dapat diterima pada saat isu kontroversial memiliki tingkat atraktif yang sama. Contoh siapa dalang di balik gerakan 30 September? Masingmasing siswa mencoba mempertahankan argumennya sesuai versi yang diyakininya. Namun, disonansi akan lebih kecil pada saat masalah tersebut dibahas lebih jauh dan rasional. Contoh kecenderungan keterlibatan Amerika Serikat sangat tinggi mengingat kondisi global saat itu dalam situasi Perang Dingin dan bagaimana kebencian AS terhadap Presiden Soekarno yang begitu besar memberi peluang pada peran PKI.

Meskipun strategi pengelolaan pembelajaran materi sejarah kontroversial di atas dianggap cukup efektif, Supriyatna (2007: 78-83) mengingatkan, penggunaannya menghendaki guru melakukan hal sebagai berikut;

1. Mendorong inisiatif siswa untuk terlibat aktif dalam mengembangkan materi pembelajaran;

2. Menggunakan data mentah dan sumber utama untuk dikembangkan dalam diskusi ;

3. Memberi tugas kepada siswa untuk mengembangkan klasifikasi, analisis, melakukan prediksi terhadap peristiwa sejarah dan menciptakan konsepkonsep baru;

4. Bersifat fleksibel terhadap respon dan interpretasi siswa dalam mesalahmasalah sejarah dan bersedia mengubah strategi pembelajaran yang tergantung pada minat siswa dan kondisi;

5. Memfasilitasi siswa untuk memahami konsep dan mengembangkan melalui dialog;

6. Mengembangkan dialog dengan rekanrekannya;

7. Menghindari alat test yang mengukur keberhasilan siswa dan menerapkan evaluasi yang bersifat on going dilakukan secara komprehensif dan terkemuka;

8. Mendorong siswa untuk membuat analisis dan elaborasi terhadap masalah-masalah kontrovesial yang dihadapinya;

9. Mengembangkan aspek kontradiksi dan kontroversi;

10. Memberi peluang siswa untuk berpikir mengenai masalah yang dihadapi; memberi peluang kepada siswa untuk membangun jaringan konsep dan membentuk metafora.

Namun lagi-lagi untuk keberhasilan strategi pengelolaan pembelajaran materi sejarah kontroversial menurut Mestika Zed (2003: 26-29), harus memperhatikan lima macam standar berpikir sejarah, yakni:

Pertama, kesadaran tentang waktu (sense of time). Dalam ilmu sejarah setiap gejala hendaklah dilihat dalam kerangka time setting tertentu. Kerangka waktu 
merupakan jantung kajian sejarah. Apabila kita menghilangkan sense of time maka berarti kita menghilangkan ciri pokok kajian sejarah;

Kedua, kesadaran tentang kontinuitas (keberlanjutan) dan diskontinuitas (perubahan). Kesadaran tentang keberlanjutan dan perubahan itu menjadi sangat penting dalam sejarah karena kajian sejarah lebih tertarik kepada hal-hal yang unik, hal-hal yang partikularistik, dan hal-hal yang dianggap berbeda dari pola umum yang ada. Dengan demikian sejarah lebih memfokuskan diri pada perubahan daripada sesuatu yang berkelanjutan. Namun perubahan tidak bisa dipahami kalau kita tidak memahami konsep keberlanjutan;

Ketiga, ketercakupan sejarah (historical comprehension). Ketercakupan sejarah bertitik tolak dari adanya keberlanjutan dan perubahan, sehingga dalam hal itu dtuntut kemampuan kita untuk memahami berbagai dimensi, baik yang bersifat tetap dan yang berubah, maupun yang berdimensi lahiriah dan batiniah dalam rangka menangkap gejala sejarah. Ketercakupan sejarah memerlukan; (1) penguasaan terminologi dan konsep-konsep dasar sejarah seperti apakah peristiwa sejarah, objek sejarah, bukti, generalisasi, keunikan sejarah. (2) kemampuan menangkap literal meaning dan inner reality dari dinamika sejarah. (3) kemampuan mengidentifikasi persoalan pokok naratif sejarah. (4) kemampuan membaca naratif sejarah secara harfiah dan imajinatif. (5) pembuktian berdasarkan perspektif sejarah. (6) kemampuan merujuk data dengan peta sejarah, pemanfaatan data visual dan matematis lewat bagan, tabel, grafik atau diagram;

Keempat, kepekaan terhadap sifat multiple causation (multi sebab). Sejarah sebagai sebuah ilmu tidak seperti ilmu alam yang biasanya menerangkan sebab sebagai yang tunggal. Dalam sejarah selalu melihat sebab dalam konstelasi yang kompleks dan serba banyak. Tidak ada dalam sejarah jawaban sebab bersifat tunggal. Dengan demikian kemampuan untuk melakukan penelitian sejarah dengan menggunakan metode dasar menjadi sangat mendasar. Oleh karena itu kemampuan melakukan penelitian sejarah pada pokoknya tidak hanya berkenaan dengan keterampilan teknis, melainkan juga harus memiliki kepekaan dalam mengenali dan menganalisis isuisu sejarah;

Kelima, kesadaran bahwa sejarah yang ditulis adalah rekonstruksi dan tidak mungkin bisa disamakan dengan apa yang sesungguhnya terjadi. Rekonstruksi sejarah dibangun atas dasar elemen fakta dan interpretasi. Fakta-fakta tidak bisa menjelaskan sendiri mengenai peristiwa yang diteliti, ia memerlukan interpretasi agar rekonstruksi sejarah dapat dilakukan. Dalam melakukan interpretasi jelas banyak faktor yang mempengaruhinya. Salah satunya adalah teori interpretasi yang digunakan oleh peneliti atau penulis sejarah. Itulah sebabnya kenapa fakta yang sama bisa menimbulkan berbagai macam interpretasi.

Sementara, kondisi prasyarat yang paling utama dimiliki oleh guru menurut Mestika Zed (2003: 466) adalah: 1) kemampuan dan kemauan menggali peristiwa kontroversial melalui riset atau paling tidak mengkaji hasil-hasil riset terkait dan terbaru; 2) melepaskan diri dari teacher centered learning, terlebih-lebih pendekatan doktrinasi berdasarkan opini dan keyakinan subjektif; (3) mumpuni dalam penguasaan sumber-sumber isu kontroversial. 


\section{KESIMPULAN}

Kelahiran Kurikulum 2013, di satu sisi membawa angin segar bagi pendidikan sejarah karena telah menempatkan pendidikan sejarah tidak hanya sebatas alat politik untuk penanaman nila-nilai kebangsaan lewat mata pelajaran Sejarah Indonesia, melainkan juga sebagai sarana akademik pengembangan berpikir ilmiah siswa lewat mata pelajaranSejarah. Namun, pada sisi yang lain diperlukan strategi pengelolaan pembelajaran yang tepat karena ke dua mata pelajaran itu tidak saja memuat ruang lingkup materi pelajaran "serupa", tetapi juga mengandung substansi materi sejarah kontroversial. Ini menjadi tantangan tersendiri bagi guru dalam mengimplementasikannya di kelas.

Dalam konteks ini ditawarkan solusi yang dianggap tepat, yakni strategi pengelolaan pembelajaran ruang lingkup materi pelajaran "serupa" berbasis nilai dan strategi pengelolaan pembelajaran substansi materi sejarah kontroversial berbasis konstruktivistik-kolaboratif. Solusi ini muncul berlandaskan kepada adanya perbedaan tujuan pembelajaran masing-masing mata pelajaran. Dengan penggunaan kedua strategi pengelolaan pembelajaran itu, tidak hanya mampu mengatasi "kegalauan" guru dalam membedakan pembelajaran Sejarah Indonesia sebagai mata pelajaran Wajib dan pembelajaran Sejarah sebagai mata pelajaran Peminatan, melainkan juga dapat mengeksplor kompetensi siswa sesuai dengan tujuan pembelajaran masingmasing.

\section{Daftar Pustaka}

Adam, Asvi Warman. Seabad Kontroversi Sejarah. Yogyakarta: Ombak. 2007

Aizid, Rizem. Menguak Kontroversi-Kontroversi Sejarah Indonesia. Cetakan Pertama. Yogyakarta: Saufa, Maret. 2014

Anonim. Peminatan Peserta Didik, Jakarta: Badan PSDM dan PMP Kemendikbud.2013a

Anonim. Naskah Kurikulum 2013 SMA/ MA/SMK/MAK Pedoman Mata Pelajaran Sejarah Indonesia. Jakarta: Kemendikbud.2013b.

Anonim. Naskah Kurikulum 2013 SMA/MA Pedoman Mata Pelajaran Sejarah. Jakarta: Kemendikbud.2013c.

Baswedan, Anies. 2014. Surat Menteri Pendidikan dan Kebudayaan RI No. 179342/MPK/ KR/2014 tentang Pelaksanaan Kurikulum 2013. Tanggal 5 Desember.

Bootzin, Richard R, et al. 1999. Psychology Today. New York: Randoom House.

Djunaidi, "Kesiapan Guru Sejarah di DKI Jakarta dalam Menyusun Instrumen Penilaian Hasil Belajar Siswa sesuai Kurikulum 2013". Laporan Rubi, Jakarta: Fakultas Ilmu Sosial, UNJ.

Education Information Centre for Education Needs and Study Courses (EICENS). http://www.edusearch.nz/2014/07/ subject-matter/.html.

Eggen, Paul dan Don Kauchak. 2012. Strategi dan Model Pembelajaran: Mengajarkan Konten dan Keterampilan Berpikir. Edisi Keenam. Jakarta: PT. Indeks.

Hasan, Hamid.2012. Pendidikan Sejarah Indonesia: Isu dalam Ide dan Pembelajaran. Bandung: Rizqi Press.

Hastuti, Elly. 2009. "Peningkatan Kesadaran Sejarah Siswa melalui Pemanfaatan Sumber Belajar Isu Kontroversial". Tesis. Jakarta: Pascasarjana UNJ. 
Kochhar, S.K. 2008. Teaching of History. Jakarta: Grasindo.

Pudjihastuti, Sri. 2004. "Pengajaran Berpikir Dalam Pendidikan Ilmu-Ilmu Sosial," Penelitian.Tasik Malaya: Tanpa Penerbit.

Sumantri, mulyani dan Nana Syaodih. 2006. Perkembangan Peserta Didik. Jakarta: Penerbit Universitas Terbuka.

Supriyatna, Nana. 2007. Konstruksi Pembelajaran Sejarah Kritis. Bandung: Historia Utama Press.

Rizem Aizid. 2014. Menguak KontroversiKontroversi Sejarah Indonesia. Cetakan Pertama. Yogyakarta: Saufa.

Sanjaya, Wina. 2008. Strategi Pembelajaran Berorientasi Standar Proses Pendidikan. Jakarta: Kencana Prenada Media Group.

Sumantri, mulyani dan Nana Syaodih. 2006. Perkembangan Peserta Didik. Jakarta: Penerbit Universitas Terbuka.

Surat Edaran Kemendikbud Nomor 156928/ MPK.A/KR/ 2013 tanggal 8 November 2013 tentang Kurikulum 2013.

Suud., Abu. 1994. "Format Metodologi Pendidikan sejarah dalam transformasi nilai dan pengetahuan," makalah seminar. Yogyakarta: HMJ Pendidikan Pejarah, IKIP Yogyakarta.

Utomo, Cahyo Budi. 2011. "Membangun Kemampuan Berpikir Kritis dan Kreatif dalam Pembelajaran Sejarah Berbasis Metakognitif." Prosiding Seminar Nasional Pendidikan Sejarah. Isola Resort UPI Bandung, 18-20 Maret.

Zed, Mestika. 2003. Metodologi Sejarah. Padang: Fakultas Ilmu-Ilmu Sosial UNP.

Zuhdi, Susanto. 2014. "Kurikulum Sejarah dalam Dua Ranah". Kompas, 06 Mei. 


\title{
Pendekatan Kontekstual: Suatu Pendekatan Alternatif Pembelajaran Sejarah Di Sekolah Menengah Atas
}

\author{
Oleh : Nur'aeni Marta \\ Pendidikan Sejarah PPS UNJ
}

\begin{abstract}
This article is reviews about contextual approach as an alternative approach to teaching history in high school. The Contextual approach of teaching history is not a new approach, but it needs to be reconsidered in order to improve the quality of teaching history in high school. The teaching of history was still dominated by conventional approach, which is more emphasis on the mastery of the material(essentialism). It is not relevance with the educational nature of history itself, that is to humanize humans. The Contextual approach is a new perspective that is based on the context of the situation, place, time and conditions of a real environment faced by students daily. The teaching of history with this approachmeant the teacher is able to relate and connect the material study with real-life conditions.
\end{abstract}

Keywords: Contextual approach, Alternative approach, Conventional approach

\begin{abstract}
Abstrak
Artikel ini mengulas tentang pendekatan kontekstual sebagai pendekatan alternatif dalam pembelajaran sejarah di Sekolah Menengah Atas. Pendekatan kontekstual bukanlah pendekatan baru, tetapi perlu dipertimbangkan kembali sebagai upaya meningkatkan kualitas pembelajaran sejarah di Sekolah Menengah Atas.Selama ini pembelajaran sejarah masih didominasi pendekatan konvensional, yang lebih menekankan pada penguasaan materi (esensialisme). Pembelajaran seperti ini tidak sesuai dengan hakekat pendidikan sejarah itu sendiri, yaitu memanusiakan manusia. Pendekatan kontekstual adalah cara pandang yang didasarkan pada konteks situasi, tempat,waktu dan kondisi lingkungan yang nyata yang dihadapi siswa sehari-hari. Dengan demikian, pembelajaran sejarah dengan pendekatan ini dimaksudkan guru mampu mengkaitkan dan menghubungkan materi yang diajarkannya dengan kondisi kehidupan nyata siswa
\end{abstract}

Kata Kunci: Pendekatan kontekstual, Pendekatan alternatif, Pendekatan konvensional

\section{PENDAHULUAN}

Sejarah sebagai warisan kolektif memiliki peranan penting dalam pembentukan identitas suatu bangsa. Oleh karena itu hampir di seluruh dunia, sejarah diajarkan di sekolah.Di Indonesia, Sejarah juga menjadi bagian dari kumpulan mata pelajaran yang terdapat di dalam Kurikulum pendidikan, khususnya Sekolah Menengah Atas yang diajarkan secara terpisah dari ilmu-ilmu sosial. Menurut Sam Wineburg sejarah diajarkan di sekolah bertujuan untuk memanusiakan manusia (Sam Wineburg, 2006: 9).Memanusiakan manusia, ini artinya bahwa pembelajaran sejarah di sekolahtidak hanya menjadikan peserta didik cerdas secara intelektual, tetapi juga memiliki moralitas, kreativitas, berbudaya dan bermartabat. Dalam konteks ini menunjukkan bahwatujuan pendidikan sejarah sejalan dengan tujuan pendidikan nasional sebagaimana yang tercantum pada UU Sisdiknas 
tahun 2003, yaitu "pendidikan nasional berfungsi mengembangkan kemampuan dan membentuk watak serta peradaban bangsa yang bermartabat dalam rangka mencerdaskan kehidupan bangsa, bertujuan untuk berkembangnya potensi peserta didik agar menjadi manusia yang beriman dan bertakwa kepada Tuhan Yang Maha Esa, berahlak mulia, sehat, berilmu, cakap, kreatif, mandiri dan menjadi warga negara yang demokratis serta bertanggung jawab"

Selain itu menurut Hamid Hasan, pembelajaran sejarah bertujuan membentuk karakter bangsa. Pembentukan karakter bangsa adalah suatu hal yang mendasar bagi keberlangsungan suatu bangsa. Di era globalisasi seperti sekarang ini, dimana arus informasi dari berbagai dunia mengalir dengan cepat dan tidak dapat dibendung, sehingga dibutuhkan "filter" bagi generasi muda sebagai penerus bangsa, supaya mereka memiliki kemampuan dalam memilih, mengolah dan bahkan memproduksi informasi.

Seorang yang berkarakter akan mampu beradaptasi dengan lingkungan global tanpa meninggalkan atau tercerabut dari akar budayanya. Mereka memiliki keterampilan dan kemampuan untuk memilih berbagai informasi yang disesuaikan dengan identitas diri dan bangsanya, sehingga ia tidak terbawa arus globalisasi yang tanpa batas. Selain itu ia memiliki kemampuan mengolah informasi untuk dijadikan kreativitas yang bermanfaat dan meningkatkan kesejahteraan bagi dirinya dan masyarakat (Tilaar, 2009: 693). Dengan kata lain tujuan pendidikan sejarah tidak hanya mencapai ranah kognitif, tetapi juga mencapai ranah afektif dan psikomotorik.
Dari uraian di atas dapat dikatakan bahwa pembelajaran sejarah di Sekolah Menengah Atas memiliki kedudukan yang strategis bagi keberlangsungan kehidupan suatu bangsa. Sekolah Menengah Atas merupakan wahana tempat berkembangnya para calon pemimpin dan penerus bangsa. Sekolah Menengah Atas merupakan tahapan jenjang sekolah yang akan menghantarkan siswa didik menuju ke perguruan tinggi. Di perguruan tinggi mereka sudah diarahkan sesuai dengan bidang keilmuan masing-masing. Untuk itu siswa pada tingkat Sekolah Menengah Atas perlu ditanamkan kesadaran sejarah sehingga pada waktu ia masuk ke perguruan tinggi, ia sudah memiliki kesadaran mengenai jati dirinya dan bangsanya.

Namun, berdasarkan fenomena umum yang terjadi dalam implementasi pembelajaran sejarah di Sekolah Menengah Atas, khususnya di Indonesia masih jauh dari yang diharapkan (Nana Supriatna, 2007). bahkan justru dari beberapa hasil penelitian menunjukkan bahwa mata pelajaran sejarah merupakan salah satu mata pelajaran yang kurang diminati oleh siswa sebagai peserta didik. Dari pengamatan peneliti di beberapa sekolah menengah atas yang ada di Jakarta salah satu sebab kurangnya motivasi siswa dalam pembelajaran sejarah antara lain adalah rendahnya kompetensi guru dalam mengkonstruksi pembelajaran sejarah yang dapat menggali makna dari peristiwa sejarah yang diajarkannya, sehingga siswa merasakan kebermanfaatan dari materi yang ia pelajari.

Perlu difahami bahwa mata pelajaran sejarah yang diajarkan di sekolah memiliki karakteristik khusus yang berbeda dengan mata pelajaran lainnya. Objek kajian mata pelajaran sejarah adalah peristiwa masa 
lampau, sehingga materinya bersifat abstrak dan tidak dapat diuji atau diulang kembali peristiwanya sebagaimana materi mata pelajaran fisika atau pengetahuan alam yang bisa diuji kembali di laboratorium. Untuk itu, pendekatan dan metode pembelajaran sejarah di sekolah tidak bisa disamakan dengan mata pelajaran lainnya. Peristiwa sejarah yang telah terjadi pada masa lalu tersebut, tentunya memiliki perbedaan zaman dan bahkan budaya, sehingga situasi dan kondisinya tidak bisa disamakan dengan zaman yang sedang dihadapi oleh siswa.

Namun demikian, masa lalu tersebut memiliki keterkaitan dengan masa kini sebagaimana Hamid Hasan mengatakan bahwa peristiwa masa lalu walaupun kejadiannya sudah final, tetapi hasil dari tindakan tersebut selalu memiliki pengaruh yang tidak berhenti hanya untuk masanya tetapi berpengaruh terhadap masyarakat tadi dalam menjalankan kehidupan barunya (Hamid Hasan, 2012), dengan kata lain kehidupan manusia masa kini merupakan suatu kesinambungan dari kehidupan manusia sebelumnya. Menurut Sam Wineburg kondisi kita sekarang merupakan "warisan" dari masa lalu, dan berdasarkan masa lalu itu kita menata kehidupan masa kini dan masa depan (Sam Wineburg, 2006).

Permasalahannya adalah bagaimanakah cara mengimplementasikan pembelajaran sejarah di Sekolah Menengah Atas, sehingga kebermaknaan dari peristiwa masa lalu tersebut dapat dirasakan oleh siswa. Kebermaknaan tersebut mengandung arti bahwa pendidikan sejarah memiliki nilai guna bagi kehidupan siswa. Dengan demikian ungkapan "belajarlah dari sejarah" bukan hanya sekedar "slogan" belaka, tetapi dapat diimplementasikan dalam kehidupan sehari-hari siswa.
Pendekatan kontekstual adalah suatu upaya menggali kebermaknaan pembelajaran sejarah dengan mengkaitkan materi pelajaran dengan konteks situasi yang ada di lingkungan siswa. Pendekatan kontekstual ini bukanlah pendekatan baru, tetapi perlu dikembangkan dan didayagunakan sebagai pendekatan alternatif dalam pembelajaran sejarah. Pendekatan kontekstual dalam pembelajaran sejarah sudah dipraktekan oleh Sam Wineburg, dan terbukti telah mampu mengkonstruksi pembelajaran sejarah yang efektif yang mampu mendorong siswa menggali makna dari peristiwa sejarah untuk memahami kondisi kekinian.

Pendekatan kontekstual sangat dipengaruhi oleh faham konstruktivism yang dikembangkan oleh Jean Piaget dan John Dewey. Menurut Jean Piaget bahwa dalam proses belajar terjadi proses konstruksi pemaknaan oleh siswa dan bukan secara pasif menerima sesuatu dari guru. (Nana Supriatna, 2007; 72). Pandangan kontruktivistikiniberanggapan bahwa dalam proses belajar siswa tidaklah "kosong" tetapi di dalam dirinya sudah terdapat pengetahuan yang diperolehnya dari pengalamannya, yang kemudian ia konstruksi dengan pengetahuan yang ia diterima selama proses pembelajaran. Menurut aliran konstruktivitik peranan guru bukan lagi sebagai sumber belajar, tetapi sebagai fasilitator. Sehingga orientasi kegiatan pembelajaran lebih ditekankan pada peranan siswa. Siswa bukan lagi sebagai objek pembelajaran, tetapi siswa adalah subjek pembelajaran.

Di dalam proses pembelajaran dikenal dengan beberapa istilah yaitu pendekatan, model, strategi, metode dan teknik pembelajaran. Pendekatan dapat diartikan sebagai titik tolak atau sudut pandang kita terhadap proses 
pembelajaran. berdasarkan pendekatan itulah model pembelajaran disusun dan diterapkan dalam kegiatan pembelajaran. Sementara yang dimaksud kontekstual adalah suatu hal yang berkaitan dengan situasi, tempat, waktu dan situasi dan kondisi lingkungan yang dihadapi siswa. Dengan demikian pendekatan kontekstual adalah cara pandang yang didasarkan pada konteks situasi, tempat,waktu dan kondisi lingkungan yang nyata yang dihadapi siswa sehari-hari. Pendekatan kontekstual akan melahirkan model pembelajaran kontekstual yang disebut Contextual Teaching \& Learning (CTL).

\section{METODE PENELITIAN}

Menurut Elaine B. Johnson, pembelajaran kontekstual (Contextual Teaching \& Learning) adalah sebuah proses pendidikan yang bertujuan menolong para siswa melihat makna di dalam materi akademik dengan konteks dalam kehidupan mereka, yaitu dengan konteks keadaan pribadi, sosial dan budaya mereka (Elaine B. Jonson, 2012). Sementara menurut Sam Wineburg, pendekatan kontekstual adalah suatu pendekatan dengan perspektif masa kini (presentisn) untuk mengkaji masa lampau. (Sam Wineburg, 2007)

Menurut Nana Supriatna, model pembelajaran kontekstual pada mata pelajaran sejarah memiliki karakteristik sebagai berikut; materi pembelajaran sejarah tidak hanya difokuskan pada masa lalu, melainkan juga ke masa depan. Pokok bahasan pembelajaran sejarah dapat dikaitkan dengan kehidupan sehari-hari siswa, pembelajaran sejarah berorientasi pada masalah sosial siswa yang sedang dihadapinya, proses pembelajaran sejarah mampu memberdayakan peserta didik memiliki keterampilan sosial yang diperlukan untuk memecahkan masalahmasalah kehidupan sehari-hari serta tantangan-tantangan masa kini dan masa depan di era global (Nana Supriatna, 2007: 87 -116).

Sedangkan berdasarkan Depdiknas kontekstual sebagai konsep belajar yang kontekstual sebagai konsep belajar yang membantu guru mengkaitkan antara materi yang diajarkan dengan situasi dunia nyata siswa dan mendorong siswa membuat hubungan antara pengetahuan yang dimilikinya dengan penerapannya dalam kehidupan mereka sehari hari.

Pendekatan kontekstual dalam pembelajaran sejarah berawal dari pemikiran bahwa kehidupan kita masa kini merupakan bagian dari kehidupan masa lalu. Kehidupan masa kini selalu terkait dengan kehidupan masa lalu. Sehingga belajar sejarah bukan hanya sekedar mengetahui peristiwa masa lalu, tetapi mampu mengali makna dari peristiwa masa lalu tersebut untuk kepentingan kehidupan siswa baik untuk masa kini maupun masa depannya (sejarah sebagai rekonstruksi sosial).

Di era globalisasi, pendekatan kontekstual dapat digunakan sebagai pendekatan alternatif dalam pembelajaran sejarah. Munculnya Pendekatan kontekstual ini disebabkan adanya ketidakpuasan terhadap pendekatan pembelajaran konvensional. Pembelajaran konvensional lebih didominasi peranan guru sebagai transmisi materi pembelajaran. Pembelajaran seperti ini sudah tidak relevan di era globalisasi seperti sekarang ini. Untuk itu pendekatan kontekstual merupakan salah satu pendekatan alternatif yang dapat digunakan dalam pembelajaran sejarah. pendekatan alternatif adalah pendekatan diluar kebiasaan (mainstream) yang secara 
umum digunakan dalam pembelajaran sejarah. (Mangunwijaya, 2007)

Penulisan ini menggunakan metode deskriptifstudi kepustakaan, hasilnya dipaparkan secara deskriptif naratif. Datadata yang digunakan dalam penulisan ini diperoleh dari hasil pengamatan lapangan dan studi pustaka.

\section{HASIL PENELITIAN DAN PEMBAHASAN}

Pentingnya mengkonstruksi pembelajaran sejarah dengan pendekatan kontekstual didasarkan pengalaman emperis bahwa pembelajaran sejarah di sekolah diajarkan terlepas dari kehidupan sehari-hari siswa. Hal ini menimbulkan anggapan dari para siswa bahwa belajar sejarah adalah menghafal fakta-fakta. Seperti telah diuraikan diatas, bahwa materi pelajaran sejarah memiliki karakteristik khusus, mata pelajaran sejarah mempelajari peristiwa masa lalu yang bersifat einmalig, dan tidak bisa dihadirkan kembali. Materi sejarah yang khas dan unik ini menjadi landasan berfikir untuk menggunakan pendekatan selain pendekatan konvensional yang terbukti tidak mampu menggali kebermaknaan dari peristiwa masa lalu. Salah satu pendekatan yang mampu memberikan kebermaknaan dari proses pembelajaran, di antaranya adalah pendekatan kontekstual.

Pendekatan kontekstual adalah suatu pendekatan yang mengupayakan siswa mampu membuat hubungan dan mengkaitkan materi sejarah dengan kehidupan realita yang dihadapi siswa. Pendekatan konstekstual berangkat dari filsafat pragmatisme yang dikembangkan oleh John Dewey, yaitu mengembangkan teori yang dilandasi oleh keinginan agar pembelajaran dibangun melalui pengalaman nyata (real experience) (Nana
Supriatna, 2007), berdasarkan teori ini kemudian dikembangkan pendekatan kontekstual.

Pendekatan ini merupakan reaksi terhadap pendekatan konvensional yang lebih menekankan pada guru sebagai pusat kegiatan belajar.Pembelajaran sejarah di sekolah lebih didominasi kegiatan penyampaian pengetahuan atau transfer of knowledges dari guru kepada peserta didik. Akibatnya siswa hanyasebagai peserta pasif danpenerima materi dari guru.

Pendekatan kontekstual sebenarnya sudah tidak asing lagi dalam dunia pendidikan, bahkan dalam proses pembelajaran guru harus mampu mengkaitkan materi yang diajarkannya dengan konteks lingkungan siswa. Namun dalam pelaksanaan di lapangan, guru cenderung melupakan atau mengabaikan kontekstualisasi dalam proses pembelajaran. Memang, kondisi ini tidak sepenuhnya adalah kesalahan guru. Beberapa guru mengeluhkan bahwa jumlah jam pelajaran sejarah yang hanya satu jam pelajaran sementara konten materi yang diajarkan sangat banyak, sehingga ia merasa kurang memiliki kesempatan untuk mengembangkan materi pembelajaran sejarah. Guru lebih menekankan pada pencapaian materi (teks book thingking), sehingga pembelajaran sejarah seringkali lepas dari konteks situasi nyata dalam lingkungan sosial siswa.

Padahal, pembelajaran sejarah bukan sekedar mempelajari masa lalu, dengan menghafalkan materi pelajaran dari A sampai Z, tetapi yang lebih penting adalah mengungkap makna dari peristiwa masa lalu tersebut untuk kepentingan masa kini dan masa yang akan datang. Hal ini sebagaimana dikatakan oleh Hansiswany Kamarga, "kita tidak lagi 
berfikir pendidikan sejarah untuk tujuan mengajarkan content sejarah, tetapi pendidikan sejarah untuk menghasilkan output manusia yang memiliki pemahaman sejarah yang bertujuan untuk membangun kemanusiaan" (Hansiswany Kamarga, 2012). Atas dasar ini, maka perlu dipertimbangkan kembali pendekatan kontekstual sebagai salah satu pendekatan alternatif dari pendekatan yang selama ini secara umum didominasi oleh pendekatan konvensional pada pembelajaran sejarah di Sekolah Menengah Atas.

Adapun pendekatan kontekstual dalam pembelajaran sejarah dapat diterapkan melalui cara-cara antara lain sebagai berikut; pertama, pembelajaran sejarah dikembangkan berdasarkan perspektif kekinian dengan mengambil isuisu yang sedang dihadapi oleh masyarakat/ bangsa, kedua penjelasan dilakukan secara geneologis, dan pemahaman jiwa zaman.

\section{Isu-Isu Kekinian Sebagai Langkah Awal Untuk Memahami Sejarah}

Pendekatan kontekstual sebagai suatu konstruksi pembelajaran sejarah dapat diawali dari kondisi realita kekinian. Pemahaman sejarah dapat dilakukan dengan melihat kondisi riil kekinian dengan masa kini sebagai titik pijaknya. Jadi masa kini sebagai star pointnya. (present stand point). Toeri ini berawal dari pemikiran filsafat Love Joy, yang menyatakan bahwa penulisan sejarah dapat dilakukan dengan titik awal dan berpangkal pada realitas yang dihadapi oleh sejarawan ketika menulis sejarahnya. Cara perfikir seperti ini dapat digunakan juga dalam proses pembelajaran sejarah. Artinya seorang guru sejarah ketika melakukan pengolahan materi pembelajaran sejarah dapat tidak berpangkal pada masa lampau sebagai titik awal pijakan, tetapi pada isu-isu dan problem-problem masa kini yang dilihat, didengar, dan difahami oleh siswa. Fakta sejarah yang bersumber pada dokumen berupa informasi masa lalu dihadirkan untuk mencari akar atau sebagai justifikasi keberadaan fenomena masa kini. Dengan demikian terjadi kontekstualisasi.

Selama ini materi sejarah diajarkan secara kronologis yang orientasinya tuturan historis bermula dari masa lampau sampai menuju masa sekarang. Pengajaran materi sejarah secara kronologis memberikan kecenderungan pembelajaran yang menekankan pada fakta-fakta sejarah, dan kurang menggali makna dari materi sejarah yang sedang dipelajari, sehingga kurang memberikan manfaat praktis bagi siswa. Hal ini menjadikan pembelajaran sejarah kurang menarik bahkan bisa membosankan, karena yang diajarkan adalah tentang fakta-fakta yang kadangkala jauh dari konteks kekinian.

Padahal untuk dapat memahami peristiwa masa lampau dapat berawal dari kondisi kekinian. Menurut Sam Wineburg, guru harus membantu para siswa melihat masa lalu yang jauh itu sebagai kulit luar dari persoalan-persoalan penting yang ada hingga saat ini. Dengan demikian pembelajaran sejarah dapat saja diawali dari isu-isu atau permasalahan kekinian.

Sehubungan dengan itu, Thorndike menyarankan pembelajaran sejarah dilakukan secara mundur atau regresif, yaitu penyajian materi sejarah dimulai dari masa sekarang ke masa lampau. Kondisi hari ini sebagai titik tolak pengkajian atau pembahasan materi sejarah. pembelajaran sejarah dengan cara ini diharapkan dapat memberikan penjelasan atas persoalan-persoalan kekinian. Sebagai contoh mengajarkan tetang perjuangan dan mempertahankan kemerdekaan Indoenesia. Untuk mengawali pembahasan guru dapat melakukan pertanyaan- 
pertanyaan sebagai berikut; mengapa Indonesia memiliki wilayah meliputi dari Sabang sampai Merouke?, mengapa penduduk Irian Jaya yang secara budaya lebih dekat dengan Papua Nugini, tetapi menjadi bagian dari bangsa Indonesia. Mengapa wilayah Indonesia juga mencakup wilayah yang berada di daratan pulau Borneo (sekarang Kalimantan), padahal di pulau itu terdapat wilayah milik Malaysia dan Brunei Darussalam. Dari permasalah-permasalahan ini kemudian dicari geneologinya atau asal usulnya melalui pembelajaran sejarah. untuk dapat menerapkan cara regresi ini, tentunya guru sejarah harus memiliki sejumlah pengetahuan terutama wacana aktual, sehingga dapat menarik perhatian siswa dalam belajar. Selain itu juga menurut Abd. Rahman Hamid, pembelajaran sejarah akan lebih menarik dan mudah difahami jika penjelasan dimulai dari kondisi realitas siswa, kemudian ditarik mundur ke belakang, dimulai dari yang terdekat dengan zamannya sampai zaman yang mempunyai jarak waktu yang jauh (Abd. Rahman, 2014: 120). Pembelajaran sejarah dengan pendekatan kontekstual ini diharapkan siswa dapat memahi peristiwa masa lalu, sehingga siswa dapat mengali makna dari materi yang ia pelajari.

\section{Pemahaman Konteks Waktu Berdasarkan Jiwa Zaman}

Seperti telah dijelaskan diatas bahwa objek materi sejarah adalah peristiwa masa lalu. Peristiwanya sendiri sudah terjadi dan tidak bisa diulang kembali, sehingga materi pelajaran secara sangat abstrak. Peristiwa masa lalu mengandung arti bahwa ada jarak waktu antara kita sekarang (present) dengan kejadian/peristiwa. Seperti diketahui bahwa di dalam waktu terdapat struktur yang menggambarkan adanya perbedaan sosial budaya manusia sesuai dengan zamannya. Oleh karenanya guru sejarah harus memiliki kemampuan memahami peristiwa sejarah sesuai dengan konteks jamannya/jiwa zaman yang disebut Historical Mindednes (Gottschalk, 1961). Hal ini dikarenakan setiap zaman memiliki kebudayaannya sendiri. Manusia sebagai mahluk yang berbudaya terus berkembang sejalan dengan perubahan zaman. Hal ini perlu disadari oleh guru sejarah sehingga ia tidak melakukan penilaian terhadap peristiwa masa lampau berdasarkan kondisi kekinian (presentism). Pandangan seperti ini akan menjadikan peristiwa sejarah keluar dari konteks zamannya, sehingga terjadi anakronisme di dalam pembelajaran sejarah.

Historical-mindedness adalah suatu kemampuan untuk menempatkan suatu gelaja sejarah sesuai dengan suasana dan iklim kebudayaan masanya (Sartono Kartodirdjo, 1992 : 70). Kemampuan menempatkan peristiwa sesuai dengan konteks zamannya dapat dikembangkan melalui kemampuan membaca teks arsip/dokumen. Oleh karenanya guru sejarah dalam mengimplementasikan pembelajaran tidak hanya menggunakan buku teks yang diberikan oleh pemerintah, tetapi juga menggunakan sumber-sumber primer yang berupa arsip/dokumen sejarah. (Sam Wineburg, 2006: 95-135). Dokumen-dokumen tersebut mengandung jiwa zaman, ini artinya bahwa lahirnya teks sejarah tidak secara tiba-tiba, tetapi ada nilai-nilai kontekstualnya, sebagaimana dalam ajaran Islam dikenal dengan istilah "asbabun nuzul". Pertanyaan mengapa di dalam arsip dinyatakan bahwa teks proklamasi dibacakan di jalan Pegangsaan Timur No. 56 bukan di jalan Proklamasi? Atau mengapa sampai ada dokumen Surat Perintah Sebelas Maret (Supersemar) dll. Dengan demikian guru sejarah harus mampu mendorong siswa untuk berfikir 
apa yang terjadi dibalik dokumen tersebut dengan memahami konteks zamannya.

Selain itu, pengetahuan sejarah juga memiliki konsep-konsep yang cara memaknainya berbeda dengan masa kini. Tidak serta merta konsep yang kekinian dipahami secara umum disamaratakan maknanya dengan konsep sejenis di masa lampau. Sam Wineburg mengambil contoh konsep imperialisme. Konsep ini pada abad 18-19 memiliki makna yang positif, tetapi sejak Pasca Perang Dunia I \& II konsep imperialisme memiliki makna yang negatif. Demikian pula lembaga pendidikan kedokteran. Pada masa kini merupakan lembaga pendidikan yang paling bergengsi, tetapi pada masa kolonial Belanda, sekolah kedokteran yang dulu disebut STOVIA bukanlah sekolah bergengsi, karena boleh dimasuki oleh golongan sosial yang lebih rendah dibandingkan dengan MOSVIA yang merupakan sekolah calon pejabat pangreh praja.

Pemahaman sejarah yang menempatkan peristiwa sesuai dengan konteksjamannya adalah penting, sehingga tidak menghakimi pelaku sejarah, yang dapat mendorong siswa besikap bijaksana. Pendekatan kontekstual memberikan kesadaran bahwa kehidupan manusia memiliki tiga dimensi waktu, yaitu masa lalu, masa kini dan masa depan. Masa kini merupakan "warisan" dan kelanjutan dari masa lalu, sementara kehidupan masa kini merupakan penataan untuk kehidupan masa depan.

\section{KESIMPULAN}

Pendekatan kontekstual bukanlah pendekatan baru dalam pembelajaran sejarah. Tetapi perlu di-revitalisasi pendekatan kontekstual ini sebagai salah satu pendekatan alternatif dalam pembelajaran sejarah yang bermakna. Pendekatan kontekstual dapat dinyatakan sebagai reaksi dari ketidakpuasan pendekatan pembelajaran sejarah konvensional yang lebih didominasi penguasaan materi (esensialisme), peranan guru hanya sebagai transmisi yaitu menyampaikan materi sesuai panduan buku teks yang diberikan pemerintah, sehingga materi sejarah "seolah-olah" lepas dengan kondisi kekinian yang sedang dihadapi siswa. Pendekatan konvensional ini menjadikan pembelajaran sejarah membosankan.

Selain itu, materi sejarah yang diajarkan cenderung seragam sesuai dengan versi pemerintah. Pembelajaran seperti ini menimbulkan anggapan bahwa sejarah merupakan milik "pemenang". Guru dan siswa kurang diberi kebebasan menafsirkan sejarah berdasarkan sudut pandang mereka. Selain itu sejarah yang diajarkan dari Sabang sampai Merouke adalah sama. Siswa yang ada di Papua memperoleh pelajaran yang sama dengan siswa yang ada di Jawa, ini menjadikan kegiatan pembelajaran sejarah terlepas dari kondisi kekinian siswa. Sehingga kebermaknaan dari peristiwa sejarah kurang dimanfaatkan oleh siswa.

Pendekatan kontekstual dalam pembelajaran sejarah dapat dilakukan dengan cara memulai pembelajaran dengan isu-isu kekinian sebagai upaya memahami sejarah, dan pemahaman konteks waktu berdasarkan jiwa zamannya. Melalui dua cara tersebut diharapkan guru dapat mendorong siswa memiliki kemampuan mengkaitkan materi sejarah dengan kondisi kekinian, sehingga siswa menemukan makna dari sejarah yang ia pelajari untuk kepentingan kehidupan realitanya. 


\section{Daftar Pustaka}

A.L.Rowse. Apa Guna Sejarah? Depok: Komunitas Bambu. 2015

E.H.Carr. Apa Itu Sejarah? Depok: Komunitas Bambu. 2014

Hamid Hasan. Pendidikan Sejarah Indonesia: Isu dalam Ide dan Pembelajaran. Editor: Agus Mulyana. Bandung: Riqzi Press. 2012

Hansiswany Kamarga \& Yani Kusmarni (edit). Pendidikan Sejarah untuk manusia dan Kemanusiaan. Jakarta: Bee Media Indonesia. 2012

Hariyono. Mempelajari Sejarah Secara Efektif. Malang: Pustaka Jaya. 1995

Henk Schulte Nordholt dkk. Perspektif Baru Penulisan Sejarah Indonesia. Jakarta: Yayasan obor. 2008

Kuntowijoyo. Pengantar Ilmu Sejarah. Yogjakarta: Yayasan Benteng Budaya. 1997

Margaret E. Gredler. Learning and Instruction : Teori dan Aplikasi. Jakarta: Kencana. 2012

Robert M. Gagne dkk. Principles of Instructional Design. USA : Wadsworth. 2005

S.K. Kochhar. Pembelajaran sejarah, Teaching of History. Jakarta: Grasindo. 2008

Sam Wineburg. Berpikir Historis: Memetakan Masa Depan, Mengajarkan Masa Lalu. Pengantar: Asvi Warman Adam. Jakarta: Yayasan obor. 2006 


\title{
Pendekatan Dekonstruksi dalam Historiografi
}

\author{
Oleh : Bahri \\ Pendidikan Sejarah PPS UNJ
}

\begin{abstract}
Deconstruction does not need to find a final meaning. What is needed is the dismantling continuously, as a process. Writing history will never be separated from the narrative, the same thing also in deconstructive history. Reconstructionist is writing a history built on the correspondence theory of empiricism is based on the belief that in order to approach the story of the past that comes closest to the truth can only be reached directly through primary sources were contemporaneous with the incident. Deconstructionist approach is a model study that questioned the traditional assumptions like factualisme empiricism, objectivity, the truth of history, ideology, the distinction firmly with descriptive fiction in the past were built by people reconstructionist and constructionist.
\end{abstract}

Keywords: Deconstruction Approach, Indonesian Historiography

\begin{abstract}
Abstrak
Dekonstruksi tidak perlu menemukan makna terakhir. Yang diperlukan adalah pembongkaran secara terus menerus, sebagai proses. Penulisan sejarah tidak akan pernah lepas dari naratif, hal yang sama pula pada sejarah dekonstruktif. Rekonstruksionisme adalah penulisan sejarah yang dibangun atas dasar teori korespondesi empirisisme yang berdasarkan keyakinan bahwa untuk mendekati cerita tentang masa lampau yang paling mendekati kejadian sebenarnya hanya dapat dicapai secara langsung melalui sumber-sumber primer yang sezaman dengan kejadian tersebut. Pendekatan dekonstruksionis adalah model kajian yang mempertanyakan asumsi-asumsi tradisional empirisisme seperti faktualisme, objektivitas, kebenaran sejarah, ideologi, pembedaan tegas dengan fiksi dalam deskriptif masa lampau yang dibangun oleh orang-orang rekonstruksionis dan konstruksionis.
\end{abstract}

Kata Kunci: Pendekatan Dekonstruksi, Historiografi

\section{PENDAHULUAN}

Tokoh terpenting pada teori dekonstruksi ini adalah Jacques Derrida (Al-Fayyadl, 2005:2) adalah keturuan Yahudi. Ia dilahirkan di El-Biar, salah satu wilayah Aljazair pada 15 Juli 1930. Pada tahun 1949 ia pindah ke Prancis, tempat ia tinggal sampai akhir hayatnya. Pada tahun 1952, ia belajar di Ecole normale supérieure, Prancis, dan pernah juga mangajar di sana sesaat sebelum kematiannya. Derrida muda dibesarkan dalam lingkungan yang agak bersikap diskriminatif.
Karya awal Derrida di bidang filsafat sebagian besar berkaitan dengan fenomenologi. Latihan awalnya sebagai filsuf dilakukan melalui kacamata Edmund Husserl. Inspirasi penting lain bagi pemikiran awalnya berasal dari Nietzsche, Heidegger, De Saussure, Levinas dan Freud. Derrida mengakui utang budinya kepada para pemikir itu dalam pengembangan pendekatannya terhadap teks, yang kemudian dikenal sebagai 'dekonstruksi'. 
Perbedaan antara pembaca non dekonstruksi dan dekonstruksi dapat dijelaskan sebagai berikut. Pembaca non dekonstruksi atau pembaca konvensional dilakukan dengan cara menemukan makna yang benar, makna terakhir, yang disebut sebagai makna optimal. Sebaliknya, pembaca dekonstruksi tidak perlu menemukan makna terakhir. Yang diperlukan adalah pembongkaran secara terus menerus, sebagai proses. Dekonstruksi dilakukan dengan cara pemberian perhatian terhadap gejala-gelaja yang tersembunyi, sengaja disembunyikan, seperti ketidakbenaran, tokoh sampingan, perempuan, dan sebagainya. Umar Junus (1996:109-109) memandang dekonstruksi sebagai persepektif baru dalam penelitian sastra. Dekonstruksi justru memberikan dorongan untuk menemukan segala sesuatu yang selama ini tidak memperoleh perhatian. Memungkinkan untuk melakukan penjelajahan intelektual dengan apa saja, tanpa terikat dengan sutu aturan yang dianggap telah berlaku universal.

\section{METODE PENELITIAN}

Ketika gelombang kritik terhadap perspektif positivisme dari ahli teoritis kritis dan humanisme dalam ilmu-ilmu sosial, maka hal yang sama terjadi dalam dunia kajian sejarah. Perspektif awal rekonstruksionisme (reconstructionism) dalam sejarah dihantam oleh serangan kaum konstruksionis (constructionism) dan terlebih-lebih badai serangan dari kaum dekonstruksionis (deconstructionism). Gugatan-gugatan ini bertitik-tolak atas eksplanasi sejarah terhadap teks dalam bukti tentang masa lalu yang coba didekati kebenarannya seobjektif mungkin.

Kartodirdjo (1975:36) tidak memakai kata referensi untuk perspektif sejarah, tetapi lebih menganalogikannya dengan istilah kerangka analitis untuk menjelaskan pendekatan yang dipakai seorang sejarawan. Sementara, Berkhofer (1973:87) untuk kata perspektif lebih mempergunakan istilah kerangka konseptual (conceptual framework). Black dan Champion (1976:124) lebih melihat istilah perspektif dengan sinonim pada konfigurasi kata-kata kerangka referensi, aliran pemikiran (school of thought), orientasi atau pendekatan.

Rekonstruksionisme menurut tradisi Barat adalah penulisan sejarah yang dibangun atas dasar teori korespondesi empirisisme yang akar kuatnya berdasarkan keyakinan bahwa untuk mendekati cerita tentang masa lampau yang paling mendekati kejadian sebenarnya hanya dapat dicapai secara langsung melalui sumber-sumber primer yang sezaman dengan kejadian tersebut. Empirisisme merupakan teori pengetahuan, epistemologi dan metode penelitian sejarah, empirisisme itu tanpa keraguan merupakan aliran pemikiran sejarah yang amat sangat berpengaruh dalam perjalanan abad XIX.

Dalam ilmu sejarah, faham rekonstruksi sejarah mendapat sokongan utama dari "bapaknya sejarah modern" Leopold von Ranke pada abad XIX di Jerman. von Ranke menganjurkan agar sejarawan menulis apa yang sesungguhnya telah terjadi dengan menggunakan sumber-sumber primer atau orisinal yang dihasilkan pada waktu peristiwa itu terjadi dan harus diteliti dengan secermatcermatnya. Menurut von Ranke, hanya dengan mengumpulkan, menilai dan memverifikasikan semua sumber yang ada, sejarawan dapat menempatkan dirinya dalam posisi untuk merekonstuksikan masa lampau secara akurat. 
Prinsip-prinsip ilmiah sejarah empiris dengan perspektif rekonstruksionis ini adalah penyelidikan yang teliti dan pengetahuan mengenai bukti-bukti sejarah yang diverifikasi dengan referensi, research yang tidak berat sebelah dan cara penalaran yang induktif yakni dari yang khusus ke yang umum. Oleh karena itu, prinsip-prinsip dalam perspektif rekonstruksionisme ini adalah teori ilmu pengetahuan yang spesifik, yaitu: pertama, masa lampau berada secara independen di luar pikiran (mind) individu dan dapat diobservasi serta diverifikasikan. Kedua, dengan konsistensi menaati prinsip-prinsip penelitian tersebut di atas, sejarawan berkesanggupan untuk mengambarkan masa lampau dengan objektif dan akurat.

Pemikir awal dari perspektif sejarah konstruksionisme ini adalah Karl Marx, Auguste Comte, dan Herbert Spencer pada abad XIX. Kaum konstuksionis merasa tidak puas dengan rekonstruksionisme dalam perspektif sejarah, yang dipandang naratif deskriptif sederhana terhadap peristiwa-peristiwa tunggal dan mempunyai ciri sendiri. Bagi kaum konstruksionis, sejarah dapat memberi eksplanasi tentang masa lampau, hanya jika bukti-bukti sejarah ditempatkan dalam kerangka eksplanatori yang berada sebelumnya yang memungkinkan seorang sejarawan membuat kalkulasi kaidahkaidah umum (general rules), yang bersifat teoritis generalitatif mengenai tindakan manusia pada masa lampau tersebut. Dengan menempatkan pola-pola perilaku dan peristiwa-peristiwa masa lampau sebagai pola umum yang mempunyai ciri tersendiri maka pola tersebut dapat diamati (Munslow, 1997: 22).

Titik awal langkah sejarah dengan perspektif konstruksionis di abad XX, bermula dari gerakan New History dari para sejarawan Perancis yang tergabung dalam jurnal Annales seperti karya-karya Marc Bloch, Emmanuel le Roy Ladurie dan Robert Darnton, Lucien Febvre, yang diteruskan oleh Labrouse, Simiand dan yang paling fenomenal Fernand Braudel yang melahirkan mazhab baru Braudellian. Pijakan aliran Annales ini semakin kuat ketika mereka disokong oleh News Historians di Amerika Serikat dengan tokoh-tokohnya seperti Anthony Giddens, F. J.Turner, Charles Beard, James H. Robinson dan Vernon L. Perrington. Teori-teori ilmu sosial mulai dijadikan kerangka kerja ilmu sejarah dalam persfektif konstruksionis, yang meninggalkan paradigma lama sejarah konvensional. Dikenal sebagai French School of les Annales, para sejarawan ini memperkenalkan pendekatan histoire totale, melihat sejarah dari perspektif pemikiran dan perbuatan rakyat kebanyakan secara menyeluruh.

Di Indonesia, Sartono Kartodirdjo menjadipeloporutamastudisejarahdengan perspektif konstruksionisme dengan pendekatan ilmu-ilmu sosialnya. Dengan karya monumental The Peasants Revolt of Banten in 1888, pada tahun 1966, Sartono Kartodirdjo menunjukan bahwa konstrukkonstruk konseptual atau teori-teori ilmu sosial seperti sosiologi, antropologi sosial dan ilmu politik mempunyai daya eksplanasi yang lebih besar dan karena itu, Beliau mengemukakan untuk mencari kondisi kausal dalam suatu fenomena sejarah. Guna memperkuat analisis, maka ilmu-ilmu sosial amat bermanfaat bagi profesi para sejarawan. (Alfian, 1992: 89).

Pendekatan dekonstruksionis adalah model kajian yang mempertanyakan asumsi-asumsi tradisional empirisisme seperti faktualisme, objektivitas, kebenaran sejarah, ideologi, pembedaan tegas dengan fiksi dalam deskriptif masa 
lampau yang dibangun oleh orang-orang rekonstruksionis dan konstruksionis.

\section{Menurut dekonstruksionisme,} dalam pandangan mereka bahasalah yang merupakan isi dari sejarah, termasuk konsep-konsep dan kategori-kategori yang dikembangkan untuk menata dan memberi penjelasan mengenai bukti sejarah. Artinya hanya dengan kekuatan figurasi linguistik, masa lampau dapat diterangkan. Pendekatan dekonstruksionis berasal dari gagasan Jacques Derrida (1930-2003) yang menyatakan bahwa pemahaman terhadap teks tidak hanya tergantung pada rujukan realitas eksternal seperti yang dipahami orang-orang empirisisme. Kelompok dekonstruksionis tidak percaya bahwa narasi sejarah dapat menyajikan sesuatu yang sesuai dengan masa lampau sebagaimana adanya.

Paham dekonstruksionis menolak dengan tegas teori persesuaian (correspondence theory) mengenai kebenaran masa lampau yang dibangun berdasarkan proposisi-proposisi yang seolah-olah sesuai dengan faktanya. Mereka juga tidak setuju dengan teori referensialitas (referentiality) yang yakin terdapat pertalian antara realitas (peristiwa, orang, benda, proses) dengan deskripsinya (ekspresi bahasa) (Munslow,1997:188). Oleh karena itu, pendekatan dekonstruksionis secara metodologis cenderung menyusun suatu teks dengan membongkar teks lainnya serta berupaya melebihi teks-teks lain dengan menyampaikan sesuatu yang tidak dikatakan dalam teks-teks lain tersebut. Artinya, makna teks disitu jauh lebih luas dari pengertian sebelumnya. Kelompok ini menekankan bahwa selalu ada intertekstualitas karena teks yang satu berhubungan dengan teks-teks lainnya. Yang ditekankan oleh kelompok ini adalah menggunakan kata "menerjemahkan" sebagai mengganti teks dengan teks lain, bukan kata "terjemahan" yang banyak dipakai oleh orang rekonstruksi dan konstruksi sebagai transformasi dari sumber buktinya.

Pendekatan dekonstruksionis mendapat sokongan dari karya-karya yang dihasilkan oleh Hayden White, Dominick LaCapra, Davis Harlan, Allan Magill, Keith Jenkins, F.R. Ankersmith, Philippe Carrard, Joan W. Scott, Patrick Joyce, Roger Chartier dan sejarawan intelektual dan budaya lainnya. Di luar Eropa, dekonstruksionisme mendapat tempatnya ketika sejarawan membahas persoalan dampak dari kolonialisme, mereka menganggap bahwa dalam sejarah orang-orang terjajah, aspek penjajah bukan pada persoalan dekolonisasi sebagai proses sebab-akibat yang ditimbulkan oleh penjajah, tetapi sebagai persoalan dekolonialisasi, menempatkan kolonial dengan bijak dalam kerangka orangorang terjajah, artinya kolonial dibicarakan sebagai bagian koloni, bukan diluar konteks modernisasi tanah koloni itu sendiri, inilah yang kemudian melahirkan paham baru yaitu postmodernisme, atau dalam kajian sejarah dikenal istilah postkolonial dan di Indonesia, sering disebut sebagai dekolonialisasi.

Kemunculan dekonstruksionisme ditandai dengan munculnya kritik terhadap rekonstruksionis dan konstruksionis. Kebenaran sejarah yang merupakan tema penting sejak RG Colling wood, bapak ilmu sejarah moderen, di awal abad 20 memperkenalkan pola penulisan sejarah yang telah diteorikan dan dimetodologikan sehingga penulisan atas suatu peristiwa di masa lalu bisa diharapkan lebih mendekati kebenaran dengan menjaga prinsip-prinsip obyektif yang dimiliki. 
Jauh sebelum kemunculan pascamodernisme, pada dasawarsa 1920-an dan 1930-an sekelompok sejarawan Perancis yang dikenal sebagai French School of les Annales, seperti yang diceritakan di atas ingin menampilkan nilai kebenaran sejarah melalui ketelitian metode berdasarkan empirisisme dan logika. Oleh sebab itu, fokus mereka tidak lagi narasi organisasi kekuasaan, otoritas politik, dan relasi ekonomi sebagai sejarah makro, tetapi kepada serpihan-serpihan peristiwa sejarah sosial sebagai suatu sejarah mikro. Bisa dikatakan les Annales memberi kontribusi kepada perspektif baru ilmu sejarah dan merupakan sumber penggalian ide pemikiran pascamodernis pada dasawarsa 1960-an di Eropa maupun Amerika Serikat. Sinisme Lyotard dan kritik Laclau serta Mouffe ini mewakili keyakinan para pemikir pascastrukturalis dan pascamodernis, yang akar pemikirannya diilhami para sejarawan les Annales. Kritik para pemikir pascastrukturalis dan pasca modernis terhadap historisisme antara lain sebagai berikut:

Pertama, mereka menolak pandangan Hegelian tentang sejarah sebagai proses kemajuan. Para filsuf ini menganggap semua ideologi yang meramalkan titik akhir sejarah sebagai teori berbahaya dan keliru. Kedua, mereka kritis terhadap konsep penalaran, teori, dan sejarah sebagai suatu pola yang disistematikakan. Mereka menolak gagasan bahwa formasi sosial merupakan totalitas yang dapat dianalisis. Ketiga, mereka sangat kritis kepada kecenderungan konformitas pada konsep maupun teori-teori ilmu sejarah yang tradisional dan konvensional. Keempat, para filsuf ini menolak historiografi yang dibangun atas dasar narasi-narasi besar yang ditulis sejarawan universal seperti revolusi dan pergantian rezim. Sebaliknya, mereka terobsesi kepada historiografi yang dibangun atas dasar narasi-narasi kecil yang ditulis sejarawan spesifik yang bekerja di wilayah keahlian khusus dan lokal dengan pendefinisian yang jelas. Sejarawan pascamodernis memfokuskan kajiannya ditingkat mikro dengan lokalitas dan spesifikasi tema yang khas seperti sejarah rokok, sejarah kota, sejarah tari, dan sejenisnya.

Menurut Foucault, para sejarawan yang membawa nilai-nilai intelektual universal dengan narasi besarnya telah ketinggalan zaman. Di masa sekarang kaum intelektual cenderung bekerja di sektor spesifik, seperti museum, rumah sakit, laboratorium, universitas, perpustakaan sehingga mereka disebut sebagai kaum intelektual spesifik. Mereka tidak merumuskan teori sistematika global yang merangkum semuanya seperti yang diyakini para sejarawan mazhab Decartesian atau konvensional melainkan menganalisis hal-hal yang lebih spesifik dan lokal. Dengan menggunakan pendekatan genealoginya Nietzsche, ilmu sejarah dituding telah memberlakukan tindakan yang tiranik melalui wacana yang ditotalisasikan dan disistematikakan secara universal dengan menundukkan, memeriferikan, serta memfragmentasikan sumber-sumber pengetahuan yang spesifik di bawah kekuasaan teori-teori besar.

Dekonstruksi merupakan aktivitas pembacaan di mana teks harus dibaca dengan cara sama sekali baru. Menurut Derrida, teks dapat menyembunyikan kekurangan, kelemahan, dan kebohongan penulis serta mengandung sejumlah ketidak konsistenan konsep bahkan kontradiksi ciptaan penulis yang menjadi landasan teks, sehingga muncul paradox dalam menggunakan konsepnya di dalam teks secara keseluruhan. Tidak seorang pun dapat membuat sarana (tanda) dan 
tujuan (makna) menjadi identik. Menurut orang dekonstruksionisme, bahasa merupakan proses temporal.

Dekonstruksionisme justru lebih kritis, ia mengganggap sejarah adalah proses yang tiada akhir. Dan secara humanisme, sejarah harus keluar dari belenggu kebenaran tunggal tersebut, sejarah bukan generalisasi teori-teori ilmu sosial. Sejarah bukanlah penjelasan semata atas fakta, tetapi lebih jauh sejarah adalah penafsiran atas fakta. Jalan yang ditawarkan oleh dekonstruksionisme dengan mengubah teks menerjemahkan bukan terjemahan teks merupakan wacana menarik dalam melihat kembali sumbersumbermasa lampau.

Penelitian ini menggunakan pendekatan penelitian sejarah. Menurut Hariyono (1995:109) meliputi langkahlangkah yaitu heuristic, kritik, interpretasi, dan historiografi. Langkah pertama dilakukan pengumpulan data (heuristic) terhadap buku-buku atau dokumendokumen yang akan dijadikan sumber data sebagai landasan untuk melakukan analisis. Jurnal-jurnal, buku-buku dan dokumen-dokumen yang dikumpulkan yaitu berkaitan dengan pendidikan dan pembentukan karakter di sekolah. Langkah kedua yaitu kritik sumber. Kritik sumber dilakukan sebagai filter secara kritis dalam melakukan penilaian sumber menyangkut otentitas dan kepercayaan sumber. Kritik dilakukan melalui 2 (dua) tahap baik kritik intern (materi sumber) maupun kritik ekstern (subtansi atau isi). Langkah ketiga yaitu interpretasi (penafsiran) yaitu peneliti melakukan penafsiran terhadap sumbersumber data yang telah dikritik baik intern maupun ekstern, dan langkah keempat yaitu historiografi (penulisan) yaitu tahapan sintesis dari hasil penyelidikan sehingga pada akhirnya melahirkan tulisan yang utuh melalui proses rekonstruksi.
Menurut Lois Gotsschalk, dalam Shofa, (2012) pada model penulisan (historiografi) menggunakan model deduktif.

\section{HASIL DAN PEMBAHASAN}

\section{Pemikiran Alun Parlow, Michel Foucault dan Hayden White Tentang Dekonstruksi Sejarah}

\section{Dekonstruksi menurut Alun Munslow}

Alun Munslow seorang guru besar sejarah dari universitas Staffordshire, dalam dekonstruksi sejarah ada empat kunci , yaitu pertanyaan tentang epistimologi, fakta, teori sosial, dan naratif. Alun Munslow menjelaskan tentang epistemologi, fakta-fakta, teori sosial, dan naratif. Epistemologi, (dari bahasa Yunani episteme (pengetahuan) dan logos (kata/ pembicaraan/ilmu) adalah cabang filsafat yang berkaitan dengan asal, sifat, dan jenis pengetahuan. Epistomologi atau Teori Pengetahuan berhubungan dengan hakikat dari ilmu pengetahuan, pengandaianpengandaian, dasar-dasarnya serta pertanggung jawaban atas pertanyataan mengenai pengetahuan yang dimiliki oleh setiap manusia.

Penulisan sejarah tidak akan pernah lepas dari naratif, hal yang sama pula pada sejarah dekonstruktif. Naratif berasal dari kata narasi yang memiliki makna pengisahan suatu cerita atau kejadian. Naratif adalah rangkaian kalimat yang bersifat narasi atau bersifat menguraikan (menjelaskan, dalam makna lain naratif di katakan sebagai prosa yang subjeknya merupakan suatu rangkaian kejadian. Naratif dalam sejarah tidak hanya bercerita, melainkan juga dengan suatu analisis yang mendalam.

Fakta (bahasa Latin: factus) ialah segala sesuatu yang tertangkap oleh indramanusia. Catatan atas pengumpulan 
fakta disebut data. Fakta seringkali diyakini oleh orang banyak (umum) sebagai hal yang sebenarnya, baik karena mereka telah mengalami kenyataan-kenyataan dari dekat maupun karena mereka dianggap telah melaporkan pengalaman orang lain yang sesungguhnya. Dalam istilah keilmuanfakta adalah suatu hasil observasi yang obyektif dan dapat dilakukan verifikasi oleh siapapun. Tanpa fakta, sejarawan tidak mampu meneliti dan menulis sejarah. Fakta menurut sejarah bersumber dari sumber-sumber sejarah. Dalam menganalisa fakta dipeerlukan sebuah kritik, ada kritik ekstren maupun interen. Kritik diperlukan untuk menguji suatu fakta atau memilah-milah atau dalam sejarah menguji otentitas dan kredibilitas suatu sumber.

\section{Dekonstruksi menurut Michel Foucault}

Foucault tidak menulis tentang sejarah tetapi hampir seluruh pemikirannya adalah tema-tema penting dalam sejarah pengetahuan. Ia tidak menulis tentang sejarah tetapi masa hidupnya sudah menghistoris, sudah berlalu menjadi puing-puing sejarah. Dan jangan salah, puing-puing ide dan gagasan-gagasan Foucault bukan puingpuing yang sudah runtuh, tumbang dan mati, melainkan puing-puing yang masih berdiri kokoh, masih hidup memberikan inspirasi tentang perlunya bersikap kritis terhadap masa silam. Puing-puing yang ternyata memberikan ilham bahwa sejarah telah berlalu tidak melalui sebuah proses yang sederhana, bahwa sejarah harus dicurigai karena penuh dengan hal-hal yang "menyesatkan." Sejarah adalah sebuah konstruksi sosial yang didalamnya terlibat kekerasan politik, kerakusan kuasa dan kolaborasi antara kekuasaan dengan pengetahuan. Sejarah telah berkembang dikendalikan oleh kekuatan-kekuatan eksploratif dan eksploitatif. Sejarah harus digali kembali, dibongkar dan ditemukan kepalsuan-kepalsuannya. Inilah yang dilakukan sekelompok ilmuwan dari madzhab ciritical theroy dimana Foucault berdiri sebagai salah satu eksponennya yangbersemangatmelakukan rekonstruksi: membongkar dan meredifinisi apa-apa yang sudah dianggap established secara konvensional dalam komunitas ilmiah.

Dibandingkan dengan para filosof sejarah yang secara sepintas dijelaskan dimuka, kedudukan Foucault sama sekali berbeda. Ia sebetulnya bukan seorang yang berada dalam jajaran filosof sejarah karena Foucault tidak secara khusus menulis tentang perkembangan sejarah, karakteristiknya dan kekuatan dibalik perkembangan historis. Dalam konsepnya tentang "history of the present," ia sedikit menggagas bahwa sejarah harus ditulis dalam perspektif masa kini dan untuk kepentingan masa kini. Selebihnya, Foucault menulis tema-tema sentral dalam sejarah yang dilihatnya secara kritis. Pemikirannya menggoyahkan semua kemapanan pengetahuan terutama konsep-konsep yang secara konvensional dipegang komunitas ilmiah hingga kini. Adalah menarik untuk melihat hubungan antara pemikiran Foucault dengan sejarah. Pemikirannya tentang banyak hal dalam sejarah begitu penting, sehingga warna pemikiran Foucault bisa diidentifikasi untuk melakukan sebuah rekonstruksi atas pemikiran sejarahnya.

Satu hal yang menonjol dari keseluruhan pemikiran Foucault adalah bahwa orang kesulitan melakukan kategorisasi atas pemikirannya ke dalam bidang-bidang tertentu. Dengan kata lain, sangat sulit mengenali sosok Foucault dalam disiplin ilmu dan pemikiran konvensional. Ia berfikir ke kedalaman dasar-dasar paradigma ilmu pengetahuan 
yang bersifat filosofis dan setelahnya hampir mustahil menempatkannya dalam block of knowledge yang ada.

Bagi Foucault, sejarah itu bukanlah masa lalu melainkan bersifat masa kini (history of the present). Ia tidak tertarik dengan sejarah masa lalu yang konvensional, mengumpulkan data sebanyak-banyaknya untuk menggambarkan masa silam selengkaplengkapnya. Dalam pembahasannya tentang present, Foucault menyebutkan bahwa studi sejarah harus selalu memiliki keterkaitan dengan masa kini. Hal itu jelas karena masa kini penuh dengan persoalan yang bisa dipecahkan dengan memahami sejarahnya pada masa silam. Dengan demikian, sebenarnya menulis sejarah itu untuk masa kini bukan untuk masa silam. Perspektfinya pun harus masa kini karena untuk kebutuhan masa kini. Tetapi Lechte mengungkapkan pertanyaan: "Jika masa kini mengendalikan perhatian dan minat sejarawan, apakah tidak berbahaya yaitu masa lalu akan mengarahkan masa kini?" Atas pertanyaan serupa ini, Foucault justru memberikan respon tentang bahayanya sejarah yang diusung oleh penganut idealisme: "Sejarah akan mengarahkan masa kini bila ide tentang sebabnya (notion of cause) dominan masalahmasalah material, dan jika kontinuitas mendominasi diskontinuitas yaitu pada level pengungkapan praktis. (Lechte 1994:111).

Berkaitan dengan ide sejarah masa kini dan masa lalu yang harus selalu direevaluasi, Foucault menggagas konsep tentang 'geneologi' (genealogy). Geneologi adalah sejarah yang ditulis untuk kepentingan-kepentingan masa kini yaitu hubungannya dengan komitmen terhadap masalah-masalah kontemporer. Sejarah perlu memasuki peristwa-peristiwa masa kini. Dengan demikian, geneologi adalah 'sejarah efektif' (effective history) yang ditulis sebagai keterlibatan kontemporer. Terinspirasi oleh Bachelard, Canguilhem dan Cavailles, Foucault menyebutkan bahwa sejarah selalu merupakan geneologi dan sebuah intervensi, dengan demikian kerangka pengetahuan dan model pemahamannya pun selalu berubah (Lechte, 112).

Kunci pemikiran Foucault tentang sejarah adalah dalam istilah yang ia sebut sebagai "epistemee" (sistem wacana). Foucault dengan kritis melihat bagaimana ilmu-ilmu berkembang dalam sejarah secara sistemik (keseluruhan sistem berfikir) dalam suatu periode, kemudian berubah secara menyeluruh dalam tahapan periode yang lain, kadang-kadang secara cepat (Leksono 2002: 22-31).

Dari uraian di atas, hubungan dengan pemikiran sejarah, posisi Foucault dapat disimpulkan sebagai berikut. Pertama, Sumbangan Foucault terhadap filsafat sejarah walaupun banyak implikasi metodologisnya yang penting lebih kepada kajian-kajian kritis dan mendalam tentang tema-tema (sejarah material). Kedua, pandangan Foucault tentang sejarah lebih subtil, lebih halus, lebih pada hal-hal yang tak teramati oleh para filosof sebelumnya. Ketiga, Foucault melihat lebih dalam yaitu melihat kekuasaan dari cara kita berbicara mengenai kenyataan, dari cara bertindak dan memperlakukan sesuatu. Keeempat, keseluruhan analisis sejarah Foucault hampir selalu merupakan pembongkaran atas realitas tersembunyi dalam sejarah yaitu kolaborasi pengetahuan dengan kekuasaan. Kelima, ide dan gagasangagasan Foucault hampir seluruhnya orisinal dalam melihat masalah yang dia kupas. Orisinalitasnya membuat pemikirannya lebih dalam dan lebih rumit dari teori-teori yang ada selama ini. Keenam, inti dari seluruh kesimpulan 
di atas, penggambaran tentang sosok Foucault diantara sejarawan lain adalah, ia sendiri sesungguhnya seorang sejarawan, tapi karena ia tidak suka sebutan itu ia adalah seorang filosof yang mengkritisi sejarah dengan menelanjangi masa lalu sedemikian rupa, termasuk kepalsuankepalsuannya mungkin lebih cocok disebut atau ditempatkan sebagai "filosof paradigma," dan diantaranya adalah paradigma sejarah.

Sebagai konsekuensi dari kerja pemikiran yang fundamental, pembongkaran Foucault atas dasardasar pengetahuan membuatnya sulit dikategorikan ke dalam disiplin pengetahuan tertentu ia sendiri tidak suka dengan pendisiplinan ketat semacam itu. Pemikirannya yang "memborbardir" kesana-kemari: sejarah, psikologi, kebudayaan, gender, antropologi, politik dan seterusnya, membuat disiplin ilmu, dalam pandangannya, menjadi relatif dan sulit dipertahankan.

\section{Dekonstruksi menurut Hayden White}

Sejak "perputaran linguistik" pada dekade 1980an dan 1990an yang berpengaruh terhadap pemikiran filsafat, budaya, sastra, termasuk juga ilmu sosial dan sejarah, beragam pertanyaan diajukan para pemikir kontemporer terhadap status dan klaim ilmiah cabangcabang pengetahuan di beragam bidang. Terlebih sejak terbitnya buku Hayden White,Metahistory (1973), "putaran linguistik" menjadi wacana perdebatan di kalangan akademisi berkait dengan status dan klaim ilmiah pekerjaan yang mereka lakukan. Buku History and Theory (1998) adalah suatu tawaran bagi pembacanya untuk mengikuti bagaimana jejak pemikiran itu berkembang selama lebih dari dua dekade dalam bidang ilmu sejarah.
Meski tidak menampilkan gambaran lengkap dari pemikiran masing-masing orang yang telah menyumbangkan gagasannya dalam perdebatan itu, buku ini paling tidak memberikan bagaimana pemikiran-pemikiran kunci tentang filsafat, sejarah, budaya, sastra dan linguistik menjadi dorongan bagi para sejarawan untuk memperhatikan kembali orientasi studi mereka dan sejauh mana keabsahan klaim ilmiah pekerjaan mereka dapat dipertahankan. Sebagai bagian dari materi presentasi perkuliahan tentang Teori dan Sejarah, paper ini mencoba mengulas gagasan yang disampaikan dalam buku sesuai dengan tafsiran dan sudut pandang penulis paper ini.

Hadyen White adalah seorang sejarawan yang lekat dengan tradisi kritik sastra dalam kajian-kajian kesejarahannya. Sebagai seorang sejarawan, karya-karya White lebih banyak mengulas pemikiran tentang sejarah, atau historiografi, dibanding peristiwa sejarah seperti biasa dilakukan para sejarawan lainnya. Bukunya yang terkenal, Metahistory: The Historical Imagination in Nineteenth Century Europe (1973) menjadi magnum opus Hayden yang menyatakan bagaimana kebenaran sejarah, fakta dan peristiwa, pada akhirnya adalah apa yang disebutnya sebagai "narasi sejarah" (historical narrative). Dibanding mewakili secara langsung "realitas masa lalu," sebuah karya sejarah lebih mewakili beragam statement dalam bentuk metafor, analogi, polisemi dan perangkat bahasa lainnya yang menjadikan peristiwa masa lalu menjadi "hidup" bagi para pembaca di masa kini. Ringkasnya, karya sejarah lebih tunduk pada ketentuan hukum linguistik dibanding peristiwa masa lalu yang tampil dalam "konstruksi" seorang sejarawan.

Secara ringkas, argumen-argumen White menekankan sebuah posisi konstruktivisme dalam penulisan 
sejarah yang hasil beragamnya ditentukan oleh posisi sejarawan dan pandangan ideologisnya pada masa kini. Bagaimanapun, konstruktivisme yang pada akhirnya menihilkan realitas dunia di luar subyek, termasuk para sejarawan yang menggali pengetahuan tentang masa lalu, menjadi persoalan terbesar dalam epistemologinya. Posisi seperti ini disampaikan dengan cukup mendalam oleh Neol Carrol di tulisan berikutnya pada bab yang sama. Dalam uraiannya, Carrol menyajikan kepada kita sebuah penyeimbang terhadap pandangan konstruktivisme atau narativisme yang disampaikan White dalam bab sebelumnya.

Adalah tugas setiap sejarawan untuk menggali sedalam mungkin dunia masa lalu melalui "jejak-jejaknya" di masa kini yang tertuang dalam dokumen, arsip dan catatan masa lalu berkait sebuah peristiwa, meski tidak dapat dihindarkan bila masingmasing-masing catatan itu mengandung pula proses seleksi, penyingkiran terhadap beragam persoalan yang ada dalam suatu peristiwa sejarah. Rekaman sejarah dalam arsip sudah tentu memiliki biasnya sendiri. Ia ditulis oleh seseorang di masa lalu dengan preferensi dan pandangan subyektifnya terhadap peristiwa yang terjadi pada masa kontemprorernya. Dalam kaitan ini, tugas sejarawan dalam "obyektivitas ilmiahnya" adalah mengurai bias-bias itu dalam tinjuan pandangan kritis untuk memilah bagaimana seleksi dan bias-bias tertentu masuk dalam rekaman sejarah (arsip, dokumen dan lainnya).

Dalam kaitan ini pandangan Carrol cukup jelas bahwa penggunaan bahasa oleh sejarawan, termasuk dalam memnggunakan metafora dan analogi yang memperkuat argumen seorang sejarawan, adalah sebuah interpretasi terhadap sejarah. Namun, interpretasi itu tidak serta merta menihilkan realitas di luar sana yang memiliki independensi dari tafsiran dan subyektivisme manusia. Ia tetap merupakan sebuah peristiwa yang layak untuk terus dikaji ulang melalui pencarian para sejarawan dengan integritas pribadi atas obyetivisme ilmiah dan sekaligus kemahirannya memanfaatkan bahasa dalam menyampaikan pandanganpandangan kesejarahannya.

\section{Mencari Format Baru Historiografi Indonesia}

Keberadaan historiografi Indonesia pascakolonial seperti yang telah dijelaskan di atas, tidak terlepas dari pemahaman teoretik tentang apa yang tercakup sebagai fakta sejarah. Seba $\operatorname{coi}$ sebuah peristiwa, sejarah hanya dikaitkan dengan sesuatu yang penting secara sosial. Bagi peristiwa yang dianggap tidak memiliki arti penting secara sosial, yang sebagian besar merupakan sejarah masyarakat kebanyakan, maka seolah-olah tidak ada sejarah di dalamnya. Jika pun ada masa lalu orang kebanyakan menjadi objek kajian, maka hanya masa lalu orang kebanyakan yang berkaitan dengan politik, khususnya ketika mereka rnenjadi pemberontak. Oleh sebab itu, biarpun Sartono telah memulai sebuah tradisi yang mengangkat orang biasa, khususnya para petani sebagai bagian dari proses sejarah Indonesia, dalam perkembangannya historio- grafi Indonesia pascakolonial tetap lebih suka melakukan reinterpretasi atau reaksi terhadap kekuasaan kolonial daripada memahami proses dan memaknai dinamika sejarah masyarakat itu sendiri. Pada saat yang sama, sejarah kehidupan sehari-hari masyarakat juga tidak mendapat perhatian. Akibatnya berbeda dengan perkembangan historiografi di tempat lain seperti India, kajian sejarah sejenis subaltern atau underside belum mendapat tempat yang memadai dalam sejarahIndonesia yang ditulis oleh sejarawan Indonesia. 
Oleh karena itu tidak mengherankan, jika konstruksi dan narasi historis tentang kehidupan sehari-hari dalam sejarah Indonesia tidak datang dari sejarawan Indonesia melainkan sebagian besar ditulis oleh sejarawan asing, seperti yang dilakukan oleh John Ingleson dan William Frederick terhadap buruh pelabuhan, prostitusi serta kehidupan sehari-hari di kampung pada masa depresi tahun 1930an, atau Ann Stoler yang menulis tentang para house maids pada masa kolonial. Cara berpikir yang sama pula yang telah membatasi sejarawanIndonesia memahami sejarah tentang pergerakan nasional Indonesia. Nasionalisme Indonesia selalu dipahami sebagai sesuatu yang hanya berdimensi politis, seperti partai politik. Padahal perkembangan nasionalisme Indonesia dapat diperbincangkan dengan realitas-realitas social masyarakat seperti ironi simbolisme yang berkaitan dengan gaya hidup masyarakat bumiputera. Ketika perjuangan pergerakan nasional Indonesia memperjuangkan identitas nasional sebagai lawan dari kolonial dan imperialisme Barat sebagai contoh, pada saat yang sama para elite dan masyarakat mengadopsi berbagai simbol Barat yang diartikan para nasionalis sebagai simbol modernisasi. Padahal dalam kenyataannya, simbol itu identik dengang kolonialisme dan imperialisme Barat. Sementara itu arah biarpun tidak bisa dinafikan bahwa beberapa karya seperti yang ditulis oleh Taufik Abdullah tentang Minangkabau, Kuntowijoyo tentang Madura, Djoko Suryo tentang Semarang, Muhlis PaEni tentang Gayo dan sejarawan lainnya telah memberikan sumbangan yang besar untuk memahami dinamika historis masingmasing masyarakat yang menjadi pokok bahasan. Persoalannya adalah, apa yang telah dilakukan oleh beberapa sejarawan akademis Indonesia itu, seperti juga diakui oleh Kuntowijoyo, tidak menggambarkan benang merah dan sebagian besar karya sejarawan Indonesia yang sampai kepada masyarakat luas dan pemahaman orang Indonesia terhadap historiografi Indonesia. Ketidakhadiran sesuatu di dalam teks dokumentasi tidak pernah dipahami sebagai hal yang menyejarah. Tidak terjadinya industrialisasi di Indonesia pada masa kolonial sebagai contoh, tidak pernah dilihat sebagai bagian dari se $\neg$ buah proses historis dari perkembangan ekonomi. Oleh sebab itu, tidak mengherankan jika tema seperti hilangnya kesem-patan Indonesia melakukan industrialisasi pada abad XIX tidak ditulis oleh sejarawan Indonesia melainkan oleh sejaraᄀwan asing, seperti yang dilakukan oleh Howard Dick. Hal serupa dapat dilihat pada konteks tuyul atau mahkluk-makh $\urcorner$ luk gaib lainnya yang secara sosio-kultural menjadi bagian dari masa lalu, dan bahkan terus hidup dalam masyarakat Indonesia. Tetapi karena tuyul dan makhluk-makhluk gaib itu dianggap tidak ada dan dokumen-dokumen juga tidak menyatakan keberadaannya, maka dianggap tidak ada sejarah yang perlu dikaitkan dengan hal itu. Setelah Peter Boomgard menulis hubungan antara perubahan ekonomi dengan tuyul, gundul, atau dan Nyi Blorong pada masa kolonial, barn muncul kesadaran bahwa yang tidak ada dan yang tidak terjadi itu ternyata juga bagian dari sejarah Indonesia.

Berdasarkan pengalaman
perkembangan historiografi Indonesia
yang telah disampaikan di atas,
epistimologi dekonstruksionis, sama
seperti tradisi empirik, bukan sesuatu
yang perlu ditakutkan. Meminjam istilah
Alun Munslow, yang paling penting
adalah adanya kesadaran dekonstruktif
untuk merekonstruksi masa lalu yang
tetap didasarkan pada fakta. Dalam
kenyataannya, sejarah sebagai realitas
objektif telah berjarak dengan sejarah


yang dipahami saat ini, sehingga tidak mungkin dihidupkan kembali seperti apa yang terjadi di masa lalu. Sementara itu, sejarah sebagai naratif juga tidak akan dapat dibangun jika tidak terdapat sejarah sebagai realitas objektif masa lalu.

Oleh sebab itu, sudah saatnya para sejarawan Indonesia berpikir secara bersama-sama mencoba merumuskan kembali prinsip-prinsip dasar filosofis dan epistimologis historiografi Indonesiasentris, tanpa perlu takut terhadap perkembangan pemikiran post-modernisme atau post-kolonial, dan menen 7 tang wacana dekonstruksi secara membabi buta. Para sejara ᄀwan di perguruan tinggi perlu memberi wawasan, substansi, dan pertanyaanpertanyaan baru melalui pembenahan terhadap kurikulum yang telah digunakan selama in sehingga para sejarawan yang dihasilkannya mampu memahami masa kini dan masa depan masyarakatnya melalui rekonstruksi dan pernaknaan terhadap masa lalu yang mendekati sejarah objektif tanpa hams dibebani oleh hanya satu epistimologi atau metodologi tertentu. Atau dalam bahasa Kuntowijoyo, sejarawan Indonesia perlu menjadikan sejarah sebagai kritik sosial, sehingga sejarah sebagai sebuah rekonstruksi dan sejarawannya tidak hanya sekedar menjadi alat pembenar dan menara gading, atau hanya mampu berdialog dengan dirinya sendiri dan takut pada penindasan serta kezaliman politis.

Mengutip Sartono Kartodirdjo, sejarahnasionaladalah simboldariidentitas nasional yang secara logis akan sangat mudah terjerumus pada egosentrisme dan kecenderungan yang memihak. Hal itu telah terbukti pada sebagian besar tulisan sejarah yang dilabelkan dengan pendekatan Indone-siasentris selama ini. Namun hal itu bukan berarti bahwa historiografi yang didasarkan pada Indonesiasentris tidak mampu menghasilkan karya sejarah Indonesia yang berkadar subjektivitas rendah. Seperti telah disebutkan, salah satu kata kuncinya, para sejarawan Indonesia harus berani dan mampu mendekonstruksi secara rasional wacana dasar dan historiografi yang ada sekarang. Hal itu merupakan salah satu langkah untuk memperkaya metodologi yang telah ada atau merumuskan sebuah metodologi alternatif, sehingga mampu merekonstruksi masa lalu Indonesia mendekati peristiwa objektif dan memberi kesempatan bukan hanya kepada elite melainkan juga rakyat dan masyarakat secara luas untuk memiliki sejarah. Historiografi tanpa rakyat dan masyarakat dan rakyat tanpa sejarah adalah tulisan sejarah yang meng-ingkari proses menyejarahnya masa lalu itu sendiri. Desakralisasi dan sekaligus dekonstruksi terhadap sejarah nasional adalah kata kunci berikutnya yang perlu dilakukan jika historiografi Indonesia tidak ingin terjebak dalam egosentrisme dan keberpihakan yang membabi buta secara tents menerus. Jika sejarah strukural dengan pendekatan ilmu-ilmu sosial belum mampu sepenuhnya menghadirkan rakyat dalam sejarah, tidak ada salahnya mencari formula alternatif untuk membangun historiografi Indonesiasentris yang berpihak kepada rakyat tanpa mengingkari kesejarahan orang besar. Oleh karena itu, tidak ada alasan untuk mengatakan epistimologi sejarah dekonstruksionis dan sejarah yang manusiawi sebagai sesuatu yang menjijikkan dan mematikan, melainkan sesuatu yang inspiratif dan berguna karena sejarah pakan kekuatan moral dan aspirasi yang menggerakkan umat manusia untuk mencapai kehidupan yang lebih baik, bahagia, dan teratur secara cerdas. 


\section{KESIMPULAN}

Pendekatan dekonstruksionis adalah model kajian yang mempertanyakan asumsi-asumsi tradisional empirisisme seperti faktualisme, objektivitas, kebenaran sejarah, ideologi, pembedaan tegas dengan fiksi dalam deskriptif masa lampau yang dibangun oleh orang-orang rekonstruksionis dan konstruksionis. Dalam pandangan dekonstruksionisme, bahasalah yang merupakan isi dari sejarah, termasuk konsep-konsep dan kategorikategori yang dikembangkan untuk menata dan memberi penjelasan mengenai bukti sejarah. Artinya hanya dengan kekuatan figurasi linguistik, masa lampau dapat diterangkan.

Paham dekonstruksionis menolak dengan tegas teori persesuaian (correspondence theory) mengenai kebenaran masa lampau yang dibangun berdasarkan proposisi-proposisi yang seolah-olah sesuai dengan faktanya. Mereka juga tidak setuju dengan teori referensialitas (referentiality) yangyakin terdapat pertalian antara realitas (peristiwa, orang, benda, proses) dengan deskripsinya (ekspresi bahasa). Oleh karena itu, pendekatan dekonstruksionis secara metodologis cenderung menyusun suatu teks dengan membongkar teks lainnya serta berupaya melebihi teksteks lain dengan menyampaikan sesuatu yang tidak dikatakan dalam teks-teks lain tersebut.

\section{Daftar Pustaka}

Alfian, T. Ibrahim. "Tentang Metodologi Sejarah", dalam T. Ibrahim Alfian, et. Al. Dari babad Hikayat Sampai Sejarah Kritis. Yogyakarta: Gadjah Mada University Press. 1992
Barthes, Roland. The Rustle of Language. New York: Anchor. 1986

Berkhofer, Robert F. Jr. A Behavioral Approach to Historical Analisys. New York: The Free Press. 1969

Derrida, Jacques. Speech and Phenomena, and Other Essays on Husserlss Theory of Signs. Terj. Peggy Kamuf. . London and New York: Routlegde. 1973

Foucault, Michel. Power/Knowledge: Selected Interview and Other Writings 19721977. Brighton: Harvester Press.1980

Green, Anna dan Kathleen Troup. The Hosuses of History: A Critical Reader in Twentieth Century History and Theory. Manchester: Manchester University Press.1999

Hook, Sidney. Social Sciences Research Council. New York: Social Sciences Research Council.1946

Kartodirdjo, Sartono.. Metode dan Didaktik Sejarah. Lembaran Sejarah No. 6. Yogyakarta: Jurusan Sejarah Ubiversitas Gadjah Mada.1975

Kellner, Hans. Language and Historical Representation: Getting the Story Crooked. History and Theory Beiheft 19.1989

Laclau, Ernesto dan Chantal Mouffe. Hegemony and Socialist Strategy: Towards A Radical Democratic Politics. London: Verso.2001

Lyotard, Jean-Francois. The Sign of History. Minneapolis: University of Minneasota Press.1989

Munslow, Alun. Deconstructing History. London and New York: Routlegde.1997

Sztompka, Piotr. The Sociology of Social Change. Jakarta: Prenanda.1993 


\title{
Public History: Suatu Tinjauan Pendahuluan
}

\author{
Oleh : Jumardi \\ Pendidikan Sejarah PPS UNJ
}

\begin{abstract}
The low attention to learners, students and the public on the history as well as the withdrawal of the application of curriculum in 2013 add to the problems of strengthening the role of history in the nation's character. This affects the poor students who want to pursue higher education studies for history or science education majors history, plus the lack of job security from the government. Government and stakeholders are obliged to fix the condition of the nation and state are already crisscrossing this. We need a breakthrough in learning activities or movements to public awareness that history is not solely belong to the ruling, but the history is the property of the entire nation of Indonesia. Public history is expected to be a breakthrough in the history closer to the people. Besides public history programs provide employment opportunities for graduates to be able to work in all areas of life, and not fixated on any one area of work. In the public program history, the public are invited to play an active role in the history of his people, so that the character of a nation is not just a slogan government alone
\end{abstract}

Keywords: low level of attention and interest, the character of the nation, public history

\begin{abstract}
Abstrak
Rendahnya perhatian peserta didik, mahasiswa dan masyarakat terhadap sejarah serta ditariknya pemberlakuan kurikulum 2013 menambah permasalahan bagi sejarah dalam perannya memperkuat karakter bangsa. Hal ini berpengaruh terhadap rendahnya peserta didik yang ingin melanjutkan studi pendidikan tinggi untuk jurusan pendidikan sejarah ataupun ilmu sejarah, ditambah tidak adanya jaminan kerja dari pemerintah. Pemerintah dan pemangku kepentingan berkewajiban untuk membenahi kondisi berbangsa dan bernegara yang terlanjur simpang siur ini. Diperlukan suatu terobosan dalam kegiatan pembelajaran ataupun gerakan penyadaran kepada masyarakat bahwa sejarah bukanlah sematamata milik penguasa, tapi sejarah adalah milik seluruh bangsa Indonesia. Public history diharapkan dapat menjadi terobosan dalam mendekatkan sejarah kepada masyarakat. Selain itu program public history memberi peluang kerja kepada lulusannya untuk dapat bekerja pada seluruh bidang kehidupan, dan tidak terpaku pada satu bidang kerja saja. Pada program public history, masyarakat diajak untuk berperan aktif dalam sejarah bangsanya, sehingga karakter bangsa bukanlah hanya sebuah slogan pemerintah saja
\end{abstract}

Kata Kunci: Rendahnya perhatian dan minat, karakter bangsa ,public history

\section{PENDAHULUAN}

Pembelajaran sejarah identik dengan tatap muka yang dilakukan sesuai dengan jam mata pelajaran sejarah, dengan metode konvensional maupun metode terbarukan namun tetap dibatasi ruang dan waktu. Peserta didik pun sepertinya sudah paham bila pembelajaran sejarah dimulai, mereka tidak perlu menyiapkan diri sebelumnya, cukup dengan membaca materi saat pembelajaran dimulai peserta didik sudah mampu mengikuti materi sejarah yang disampaikan. Di masyarakat terlanjur berkembang bahwa pendidikan sejarah atau ilmu sejarah tidak mampu menghubungkan kejadian sehari-hari, bahkan pendidikan sejarah atau ilmu sejarah tidak mampu memberi dampak bagi lulusannya. Di masyarakat lebih menyukai bila anaknya mampu menguasai 
pelajaran selain sejarah terutama ilmu-ilmu eksakta. Hal ini diperparah dengan kondisi generasi muda terutama mahasiswa yang kurang kepedulian terhadap sejarah bangsanya.

Karakter bangsa tidak semata bisa dihasilkan hanya dengan mengikuti pendidikan sejarah di sekolah, namun dibutuhkan kegiatan lain. Di Indonesia fakta sejarah hanya terpampang jelas pada nama jalan seperti Jalan Jenderal Sudirman, Jalan Pangeran Antasari, Gedung Juang atau Patung Pemuda. Sesekali Jika ingin lengkap peserta didik tanpa terkecuali masyarakat harus bersedia membaca buku tentang sejarah perjuangan bangsa. Hal ini dianggapkaku dan kurang memperhatikan perkembangan media massa atau media lainnya.

Penamaan Jalan, gedung atau patung memiliki alasan dan latar belakang. Namun demikian peran mengenalkan informasi singkat tentang hal dimaksud belum sepenuhnya dilaksanakan oleh pemerintah. Seyogyanya Informasi singkat tersebut dapat ditulis dan dapat dibaca saat dilintasi atau dilalui. Selain itu media film saat ini sudah mulai mengeliat. Beberapa film dengan berlatarbelakang sejarahsudah banyak hadir di masyarakat. Meskipun dari segi penggalian sumber kesejarahan dirasa masih kurang. Kekurangan dalam sumber kesejarahan, tentunya masih dapat ditolerir bila hanya mengejar nilai ekonomis semata. Namun bila kekurangan sumber kesejarahan dalam rangka membentuk opini baru mengenai sejarah bangsa perlulah kiranya dikritisi. Sebagai contoh, masyarakat Indonesia terutama peserta didik hanya disuguhkan peran pahlawan yang sejak dibangku sekolah, sementara negara Indonesia bukanlah lahir dari peran pahlawan saja. Untuk itulah pengalian sumber sejarah sangat dibutuhkan supaya masyarakat memahami akan sejarah bangsanya. Masyarakat perlu diajak dekat dengan sejarahnya sehingga sejarah bangsa Indonesia makin dicintai oleh warga bangsanya sendiri.

Pengalian sumber kesejarahan merupakan salah satu strategi membawa sejarah ke masyarakat. Masyarakat harus dianggap memiliki sejarahnya karena masyarakat adalah bagian dari sejarah bangsa Indonesia. Kegiatan melibatkan masyarakat dalah sejarah salah satu bagian dari public history, dimana masyarakat dibangun kesadarannya akan pentingnya memahami sejarah bangsanya.

\section{METODE PENELITIAN}

National Council Public history mendefinisikan public history sebagai "gerakan, metodologi, dan pendekatan yang mempromosikan studi kolaboratif dan praktek sejarah untuk membuat wawasan khusus dan berguna bagi masyarakat".

Dari definisi ini dapat dijelaskan bahwa public history merupakan sebuah program yang diperuntukkan bagi pengembangan kesejarahan dengan metodologi dan promosi kolaboratif sebagai bagian untuk membuka wawasan bagi masyarakat. Susanto Zuhdi, berpendapat "Jangan lagi penelitian sejarah itu tersimpan di laci akademis".

Steven F dari Austin University menjelaskan bahwa Sejarawan publik ini, menafsirkan, dan membantu untuk melestarikan sejarah di berbagai tempat dan format yang beragam. Secara khusus, sejarawan publik berusaha untuk menerapkan keterampilan sejarah, pengetahuan, dan wawasan dalam pengaturan publik dan untuk khalayak umum tidak sering dikaitkan 
dengan sejarah dalam suasana akademik, seperti arsip, museum, situs bersejarah, lembaga-lembaga publik dan swasta dan perusahaan, dan organisasi profit

Paul Ashton, seorang Profesor di University of Techonology, Sdyney, Australia menulis sebuah artikel public history tentang peran toko buah orang Italia di Sdyney, mengapa demikian, karena toko tersebut berperan membentuk dan mempengaruhi cara makan, hidup, dan berpikir orang Australia. Hingga kini, warga Sydney merawat dan membanggakan toko itu.

\section{HASIL DAN PEMBAHASAN}

Minat peserta didik dan masyarakat terhadap sejarah harus diakui memang rendah. Hal ini dipengaruhi oleh beberapa hal diantaranya; kurang minat baca, motivasi kurang, sejarah dianggap tidak membawa dampak dalam kehidupan sehari-hari, sejarah belum dapat dijadikan sandaran hidup jika sudah menyelesaikan studinya dan yang tidak kalah penting, dimasyarakat terjadi kristalisasi pemahaman bahwa sejarah adalah sesuatu ilmu yang tidak penting bagi kehidupan bermasyarakat, berbangsa dan bernegara.

Menyikapi hal ini perlu kedewasaan bagi pemangku kepentingan khususnya sejarah untuk berbenah diri, bagaimana merubah pemikiran yang terlanjur berkembang dimasyarakat dan peserta didik. Diperlukan suatu model pemasaran (meminjam istilah ekonomi) bagi suatu produk supaya lebih dikenal dan kemudian merubah pola pikir.

Istilah public history di Indonesia masih menjadi barang baru. Namun di berbagai negara public history sudah menjadi kajian bahkan disebahagian kampus sudah berupa jurusan atau program studi.

Di Indonesia, public history belum dapat berbicara banyak, hal ini dikarenakan adanya pemahaman tafsir tunggal tentang sejarah itu sendiri. di era reformasi saat ini seyogyanya peran public history bisa berjalan optimal. Sumber-sumber sejarah selain tulisan misalnya foto bersejarah sebagai bagian dari memori kolektif banyak tersimpan di masyarakat dan belum dioptimalkan baik oleh sejarahwan maupun oleh pemerintah. Termasuk peran sebahagian pahlawan lokal (daerah) yang belum diakui oleh pemerintah.

Pada praktiknya public history banyak dimainkan oleh penguasa yang memahami kondisi rakyatnya dan dalam rangka melanggengkan kekuasaannya. Seperti pembuatan film, foto atau pun tulisan yang menyudutkan satu golongan atau kelompok. Seperti dikatakan oleh Elizabeth Drexle, dalam diskusi terbatas dengan tajuk; The Challenges of Research on US-Indonesia Relations: A Perspective on a Public History Research" oleh Pusat Kajian Wilayah Amerika Serikat di Kampus UI Salemba.

Public history di Indonesia justru banyak dimainkan oleh masyarakat yang boleh jadi pemahaman akan materi kesejarahannya tidak begitu tebal dibanding sejarahwan itu sendiri. Namun karena masih memiliki kesadaran akan sejarah bangsanya dilakukanlah kegiatan yang mendekatkan sejarah kepada masyarakat seperti yang dilakukan oleh Mixi Imajimimetheatre . Mixi melakukan "Nyusur history Indonesia" dengan menyadarkan masyarakat akan keanekaragaman adat dan sumber daya alam serta warisan budaya yang masih terjaga dibeberapa pulau dan nusantara di 
tanah air. Kegiatan Mixi Imajimimetheatre selain memiliki efek meningkatnya kesadaran akan sejarah bangsanya juga memiliki efek ekonomi terutama bidang pariwisata, sehingga Indonesia akan lebih dikenal dan tidak hanya Bali yang menjadi tujuan wisata.

Dalam dunia kerja, para lulusan progam public history Steven F Austin University dijelaskan dapat memasuki dunia kerja seperti berikut :

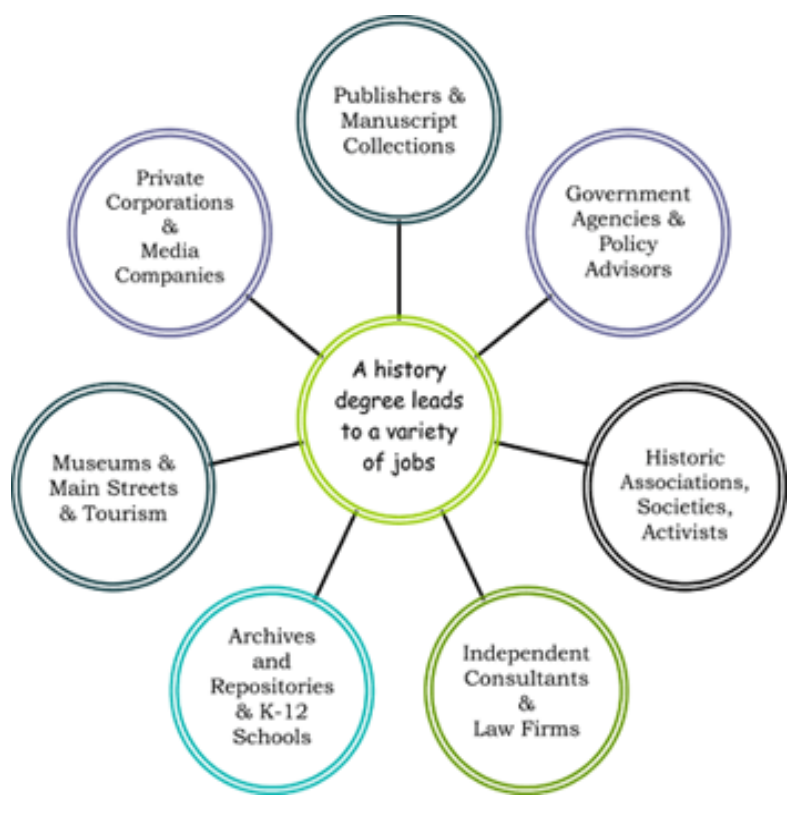

Hal ini tentunya akan menambah gairah peserta didik untuk memasuki program public history.

Apresiasi patut disampaikan kepada Gubernur DKI Basuki Tjahaya Purnama, dalam rangka ulang tahun Kota Jakarta ke - 448, akan meluncurkan KRL tematik museum. Masyarakat pengguna disuguhkan sebuah informasi tentang jenis transportasi yang pernah melayani warga Jakarta.

Selain itu, Metro TV melalui programnya "Melawan Lupa" merupakan bagian dari public history. Karena sesungguhnya masyarakat juga bagian dari sejarah yang merupakan memory kolektif. Harus diakui, bahwa banyak tema sejarah yang dalam penulisannya selalu terdapat kontroversi. Namun demikian kontroversi tersebut seyogyanya dilakukan diruang sendiri. Masyarakat membutuhkan informasi kesejarahan dalam kaitannya pembentukan karakter bangsa bukan pemecah belah bangsa.

Kreatifitas dalam menyampaikan informasi kesejarahan kepada masyarakat sangatlah dibutuhkan. Dengan sendirinya masyarakat termasuk peserta didik tentunya merasa memiliki akan sejarah bangsanya dan tidak melulu hanya berbicara mengenai peran orang besar dalam membangun bangsa ini.

\section{KESIMPULAN}

Kesadaran akan sejarah bangsanya bukan hanya milik siswa di kelas atau di sekolah. Masyakarat luas pun punya hak yang sama dalam memperoleh informasi tentang sejarah bangsanya. Peran mengetengahkan informasi kesejarahan pada masyarakat luas menjadi tanggung jawab pendidikan sejarah dan ilmu sejarah. Tentunya juga dibutuhkan dukungan yang kuat dari pemerintah.

Pembentukan karakter bangsa tidaklah semata-mata hanya didapat dari bangku sekolah. Informasi tentang sejarah keluarga, kebiasaan masyarakat suatu daerah serta model kepemimpinan menjadi faktor penentu pembentukan karakter bangsa.

Public history juga mempersiapkan lulusanya untuk bisa bekerja disegala bidang. Tentunya untuk menwujudkan hal tersebut tidaklah dibutuhkan waktu singkat dan harus dilakukan penelitian lanjutan tentang public history agar dapat dijadikan suatu program belajar ditingkat perguruan tinggi. 


\section{Daftar Pustaka}

Mengenal kembali narasi dibalik sejarah public, http://www.ui.ac.id/berita/html, diakses 20 Mei 2015

Nyusur history Indonesia ingatkan penghuni public yang lupa ruang public,http://www.bandungmagazine. commovement/, diakses 20 Mei 2015

Public History, http://www.sfasu.edu/ publichisto ry/, diakses 23 Mei 2015

Robert Kelley, Public History: Its Origins, Nature, And Prospects , http://www.history. ucsb.edu/pdf . Diakses 20 Mei 2015, Jam 20.00 WIB artikel di Majalah Historia online oleh

Hendaru Tri Hanggoro, http://historia.id/ mondial/mengembalikan-sejarah-kepublik, diakses pada 23 April 2015,

Visi Misi Jokowi-Jk, http://kpu.go.id/pdf, diakses 22 Mei 2015

Ahok coba gerbong krl commuter line tematik museum. , http://news.metrotvnews. com, diakses 23 Mei 2015

From the syllabus for Introduction to Public History taught by Michael

Gordon at the University of Wisconsin, Milwaukee , https:/www4.uwm.edu/ letsci/history/faculty/gordon.cfm

Jennifer Evans What is Public History, http:// www.publichistory.org/what_is/ definition.html

Emma Wilmer, Emeritus Editor, PHRC, http:// www.publichistory.org/about_phrc/ managing.asp, diakses 22 Mei 2015 


\title{
Reaktualisasi Nilai Sosial Budaya Melalui Pendidikan Dan Pembentukan Karakter Bangsa Di Sekolah
}

\author{
Oleh : Jumadi
}

Fakultas Ilmu Sosial Universitas Negeri Makassar

\begin{abstract}
Character education is one of the answers to the formation of national character. Character education has become a mission in an effort to realize the vision of national development. Design education and character formation in macro is done through the process of planning, implementation, and evaluation of outcomes involving all sectors of life, while the micro constructed and formed in the four pillars of teaching and learning activities in the classroom, activities of daily life in the form of cultural education unit, the activities co-curricular and extra-curricular and daily activities at home and in the community.
\end{abstract} Keywords: Education, Character Building, Social and Cultural Values, School

\begin{abstract}
Abstrak
Pendidikan karakter adalah salah satu jawaban untuk pembentukan karakter bangsa. Pendidikan karakter telah menjadi misi dalam upaya mewujudkan visi pembangunan nasional. Desain pendidikan dan pembentukan karakter secara makro dilakukan melalui proses perencanaan, pelaksanaan, dan evaluasi hasil yang melibatkan seluruh sektor kehidupan, sedangkan secara mikro dibangun dan dibentuk dalam empat pilar yaitu kegiatan belajar mengajar di kelas, kegiatan keseharian dalam bentuk budaya satuan pendidikan, kegiatan kokurikuler dan ekstra-kokurikuler serta kegiatan keseharian di rumah dan dalam masyarakat.
\end{abstract}

Kata Kunci: Pendidikan, Pembentukan Karakter, Nilai Sosial Budaya, Sekolah

\section{PENDAHULUAN}

Berbagai persoalan yang dihadapi oleh bangsa Indonesia dewasa ini, salah satunya ditengarai sebagai akibat memudarnya karakter yang dimiliki oleh warga Negara. Memudarnya karakter tentunya banyak faktor yang menjadi penyebab diantaranya derasnya gelombang globalisasi yang telah membius masyarakat Indonesia dewasa ini sehingga seolah-olah bahkan lupa akan karakternya sebagai bangsa yang memiliki kekuatan sosial-budaya sebagai bangsa yang merdeka.
Sebagai bentuk tanggungjawab negara untuk mengembangkan karakter bangsa, maka dibuatlah Undang-Undang Republik Indonesia Nomor 17 Tahun 2007, yang secara tegas dan jelas telah menempatkan pendidikan karakter sebagai misi pertama dari delapan misi dalam mewujudkan visi pembangunan nasional, yaitu "terwujudnya karakter bangsa yang tangguh, kompetitif, berakhlak mulia, dan bermoral berdasarkan Pancasila, yang dicirikan dengan watak dan perilaku manusia dan masyarakat Indonesia yang beragam, beriman dan bertakwa kepada Tuhan Yang Maha Esa, berbudi luhur, bertoleran, bergotongroyong, berjiwa 
patriotik, berkembang dinamis, dan berorientasi ipteks (Hasnawi, dkk, 2010:4).

Secara subtansi pengembangan pendidikan karakter bangsa adalah pengembangan dari seluruh aspek daripada potensi-potensi keunggulan bangsa yang bersifat multidimensional karena pengembangan potensi-potensi unggul merupakan urgensi pendidikan karakter yang sesungguhnya dalam rangka mewujudkan tujuan bangsa yaitu mencerdaskan kehidupan bangsa. Konseptualisasi mencerdaskan kehidupan bangsa sejalan dengan isu pendidikan karakter yaitu membangun manusia Indonesia yang cerdas dan berbudaya. (Hasnawi, dkk, 2010:5).

Pentingnya kebijakan yang berkaitan dengan pendidikan karakter bangsa, diantaranya dapat dipahami dalam sejarah perjalanan bangsa Indonesia, khususnya di masa pemerintahan Ir. Soekarno, pernah menyatakan sebuah konsep yang berkaitan dengan pengembangan karakter bangsa dengan konsep nation and character building yang diartikan sebagai pembangunan karakter bangsa. Ir.Soekarno bercita-cita untuk membangun bangsa Indonesia dengan karakter yang dimiliki oleh bangsa Indonesia. Begitupun secara konstitusional dapat ditemukan dalam keempat alinea didalam Pembukaan Undang-Undang Dasar 1945.

Komitmen tersebut merupakan kristalisasi dari semangat kebangsaan yang secara historis mengkristal dalam wujud gerakan Kebangkitan Nasional 1908, Sumpah Pemuda 28 Oktober 1928, yang berpuncak dengan Proklamasi Kemerdekaan Indonesia 17 Agustus 1945. Karena itu, kekhawatiran seluruh komponen bangsa tentang kondisi bangsa yang dirasakan mengkhawatirkan saat ini, dan prospek bangsa dan negara Indonesia di masa depan, sangatlah beralasan. Berbagai diskusi, seminar, sarasehan, simposium dan sejenisnya yang saat ini marak di seluruh wilayah Indonesia, merupakan indikator yang kuat bahwa seluruh komponen bangsa memiliki komitmen kebangsaan yang sangat kuat. Namun demikian diperlukan adanya kebijakan nasional yang komprehensif, koheren, dan berkelanjutan (Udin, S.W., 2009).

Berdasarkan latar belakang tersebut, maka permasalahan pokok dalam tulisan ini adalah bagaimana mengembangkan (pendidikan dan pembentukan) karakter di sekolah. Dengan demikian tujuan dan manfaatnya adalah untuk mengetahui pentingnya pendidikan karakter di sekolah, pembentukan karakter peserta didik di sekolah dan pengintegrasian pendidikan karakter di sekolah, sehingga member manfaat bagi siswa, guru, sekolah, dan bangsa untuk menghasilkan peserta didik yang memiliki karakter yang sesuai dengan nilai dan sosial budaya bangsa Indonesia.

\section{METODE PENELITIAN}

Menurut Baier (Mulyana, 2004: 8) nilai sering kali dirumuskan dalam konsep yang berbeda-beda, hal tersebut disebabkan oleh sudut pandangnya yang berbeda-beda pula. Seorang sosiolog mendefinisikan nilai sebagai suatu keinginan, kebutuhan, dan kesenangan seseorang sampai pada sanksi dan tekanan dari masyarakat.

Kupperman (Mulyana, 2004: 9) menafsirkan nilai sebagai patokan normatif yang mempengaruhi manusia dalam menentukan pilihannya diantara cara-cara tindakan alternatif. Sedangkan Kluckhohn (Brameld, 1957) mendefinisikan nilai sebagai konsepsi (tersirat atau tersurat, 
yang sifatnya membedakan individu atau ciri-ciri kelompok) dari apa yang diinginkan, yang mempengaruhi pilihan terhadap cara, tujuan antara dan tujuan akhir tindakan. Menurut Brameld, pandangan Kulchohn tersebut memiliki banyak implikasi terhadap pemaknaan nilai-nilai budaya dan sesuatu itu dipandang bernilai apabila dipersepsi sebagai sesuatu yang diinginkan.

Sementara itu, Mulyana (2004:11) menyederhanakan definisi nilai sebagai suatu rujukan dan keyakinan dalam menentukan pilihan. Menurutnya, definisi ini dapat mewakili definisi-definisi yang dipaparkan di atas, walaupun ciriciri spesifik seperti norma, keyakinan, cara, tujuan, sifat dan ciri-ciri nilai tidak diungkapkan secara eksplisit.

Dalam teori nilai yang digagasnya, Spranger (Mulyana, 2004: 32) menjelaskan ada enam orientasi nilai yang sering dijadikan rujukan oleh manusia dalam kehidupannya. Dalam pemunculannya, enam nilai tersebut cenderung menampilkan sosok yang khas terhadap pribadi seseorang. Ke-enam nilai tersebut adalah sebagai berikut:

1. Nilai teoretik: Nilai ini melibatkan pertimbangan logis dan rasional dalam memikirkan dan membuktikan kebenaran sesuatu. Nilai teoretik memiliki kadar benar-salah menurut pertimbangan akal.

2. Nilai ekonomis: Nilai ini terkait dengan pertimbangan nilai yang berkadar untung-rugi. Objek yang ditimbangnya adalah "harga" dari suatu barang atau jasa. Karena itu, nilai ini lebih mengutamakan kegunaan sesuatu bagi kehidupan manusia.

3. Nilai estetik: nilai estetik menempatkan nilai tertingginya pada bentuk dan keharmonisan. Apabila nilai ini ditilik dari subyek yang memiliknya, maka akan muncul kesan indah-tidak indah.

4. Nilai sosial: Nilai tertinggi dari nilai ini adalah kasih sayang di antara manusia. Karena itu kadar nilai ini bergerak pada rentang kehidupan yang individualistik dengan yang altruistik.

5. Nilai politik: Nilai tertinggi dalam nilai ini adalah kekuasaan. Karena itu, kadar nilainya akan bergerak dari intensitas pengaruh yang rendah sampai pengaruh yang tinggi (otoriter).

6. Nilai agama: Secara hakiki sebenarnya nilai ini merupakan nilai yang memiliki dasar kebenaran yang paling kuat dibandingkan dengan nilai-nilai sebelumnya. Nilai ini bersumber dari kebenaran tertinggi yang datangnya dari Tuhan.

Menurut Scheler (Mulyana, 2004: 38), nilai dalam kenyataannya ada yang lebih tinggi dan ada juga yang lebih rendah jika dibandingkan dengan yang lainnya. Oleh karena itu, nilai menurut Scheler memiliki hierarki yang dapat dikelompokkan ke dalam empat tingkatan, yaitu:

1. Nilai kenikmatan. Pada tingkatan ini terdapat sederet nilai yang menyenangkan atau sebaliknya yang kemudian orang merasa bahagia atau menderita.

2. Nilai kehidupan. Pada tingkatan ini terdapat nilai-nilai yang penting bagi kehidupan, misalnya kesehatan, kesegaran badan, kesejahteraan umum dan lain-lain.

3. Nilai kejiwaan. Pada tingkatan ini terdapat nilai kejiwaan yang sama 
sekali tidak bergantung pada keadaan jasmani atau lingkungan. Nilainilai semacam ini adalah keindahan, kebenaran dan pengetahuan murni yang dicapai melalui filsafat.

4. Nilai Kerohanian. Pada tingkatan ini terdapat nilai yang suci maupun tidak suci. Nilai-nilai ini terutama lahir dari ketuhanan sebagai nilai tertinggi.

Hierarki nilai tersebut ditetapkan Scheler dengan menggunakan empat kriteria, yaitu: semakin lama semakin tinggi tingkatannya; semakin dapat dibagikan tanpa mengurangi maknanya, semakin tinggi nilainya; semakin tidak tergantung pada nilai-nilai lain, semakin tinggi esensinya; semakin membahagiakan, semakin tinggi fungsinya.

Pendidikan Nilai menurut Mulyana (2004:11), adalah rujukan dan keyakinan dalam menentukan pilihan. Nilai merupakan sesuatu yang diinginkan sehingga melahirkan tindakan pada diri seseorang.MenurutFrankel(Kartawisastra, 1980: 1) nilai adalah standar tingkah laku, keindahan, keadilan, kebenaran, dan efisiensi yang mengikat manusia dan sepatutnya untuk dijalankan dan dipertahankan. Ditegaskan oleh Amborise dalam Mulyana (2004:23), bahwa nilai itu sifatnya relatif yang merupakan landasan bagi perubahan dan dapat ditanamkan melalui berbagai sumber seperti keluarga, masyarakat, agama,media massa, tradisi, dan dalam pergaulan. Rokeach dalam Mulyana (2004:27) membuat klasifikasi nilai menjadi dua yakni nilai instrumental dan nilai terminal.

Nilai merupakan fondasi penting dalam menentukan karakter suatu masyarakat dan suatu bangsa. Nilai tidak tumbuh dengan sendirinya, tetapi melalui proses penyebaran dan penyadaran, yang salah satunya adalah pendidikan di sekolah. Pendidikan nilai menurut Mulyana (2004:119) adalah pengajaran atau bimbingan kepada peserta didik agar menyadari kebenaran, kebaikan, dan keindahan melalui proses pertimbangan nilai yang tepat dan pembiasaan bertindak yang konsisten. Pendidikan nilai dimaksudkan untuk membantu peserta didik agar memahami, menyadari, dan mengalami nilai-nilai serta mampu menempatkannya secara integral dalam kehidupan. Secara khusus menurut APEID (Asia and the Pasific Programme of Educational Innovation for Develompement) pendidikan nilai ditujukan untuk :1) Menerapkan pembentukan nilai kepada anak, 2) Menghasilkan sikap yang mencerminkan nilai-nilai yang diinginkan, 3) Membimbing perilaku yang konsisten dengan nilai-nilai tersebut.

Kohlberg et al. (Djahiri, 1992: 27) menjelaskan bahwa Pendidikan Nilai adalah rekayasa ke arah: (a) Pembinaan dan pengembangan struktur dan potensi/ komponen pengalaman afektual (affective component \& experiences) atau "jati diri" atau hati nurani manusia (the consiense of man) atau suara hati (al-qolb) manusia dengan perangkat tatanan nilai-moralnorma. (b) pembinaan proses pelakonan (experiencing) dan atau transaksi/interaksi dunia afektif seseorang sehingga terjadi proses klarifikasi niai-moral-norma, ajuan nilai-moral-norma (moral judgment) atau penalaran nilai-moral-norma (moral reasoning) dan atau pengendalian nilaimoral-norma (moral control).

Dahlan (2007:5) mengartikan Pendidikan Nilai sebagai suatu proses kegiatan yang dilaksanakan secara sistematis untuk melahirkan manusia yang memiliki komitmen kognitif, komitmen afektif dan komitmen pribadi yang 
berlandaskan nilai-nilai agama. Sementara itu, Soeleman (1987:14) menambahkan bahwa Pendidikan Nilai adalah bentuk kegiatan pengembangan ekspresi nilainilai yang ada melalui proses sistematis dan kritis sehingga mereka dapat meningkatkan atau memperbaiki kualitas kognitif dan afektif peserta didik.

Adapun tujuan Pendidikan Nilai menurut Apnieve-UNESCO (1996:184) adalah untuk membantu peserta didik dalam mengeksplorasi nilai-nilai yang ada melalui pengujian kritis sehingga mereka dapat meningkatkan atau memperbaiki kualitas berfikir dan perasaannya. Sementara itu, Hill (1991:80) meyakini bahwa Pendidikan Nilai ditujukan agar siswa dapat menghayati dan mengamalkan nilai sesuai dengan keyakinan agamanya, konsesus masyarakatnya dan nilai moral universal yang dianutnya sehingga menjadi karakter pribadinya. Secara sederhana, Suparno (2002:75) melihat bahwa tujuan Pendidikan Nilai adalah menjadikan manusia berbudi pekerti. Hakam (2000:8) dan Mulyana (2004: 119) menambahkan bahwa pendidikan nilai bertujuan untuk membantu peserta didik mengalami dan menempatkan nilai-nilai secara integral dalam kehidupan mereka.

Dalam proses Pendidikan Nilai, tindakan-tindakan pendidikan yang lebih spesifik dimaksudkan untuk mencapai tujuan yang lebih khusus.

Secara filosofis, pendidikan adalah sebuah tindakan fundamental, yaitu perbuatan yang menyentuh akar-akar hidup kita sehingga mengubah dan menentukan hidup manusia. Pendidikan adalah untuk kehidupan, bukan untuk memenuhi ambisi-ambisi yang bersifat pragmatis. Pendidikan bukan non vitae sed scholae discimus (belajar bukan untuk kehidupan melainkan untuk sekolah).
Pendidikan harus bercorak non scholae sed vitae discimus, kita belajar bukan untuk sekolah melainkan untuk kehidupan. Dalam pendidikan untuk kehidupan, hal utama yang dilakukan adalah menenamkan nilai-nilai. Pendidikan nilai bukan saja perlu karena dapat mengembalikan filosofi dasar pendidikan yang seharusnya non scholae sed vitae discimus, namun juga perlu karena ciri kehidupan yang baik terletak dalam komitmen terhadap nilai-nilai: nilai kebersamaan, kejujuran, kesetiakawanan, kesopanan, kesusilaan, dan lain-lain.

Penelitian ini menggunakan pendekatan penelitian sejarah. Menurut Hariyono (1995:109) meliputi langkahlangkah yaitu heuristik, kritik, interpretasi, dan historiografi. Langkah pertama dilakukan pengumpulan data (heuristic) terhadap buku-buku atau dokumendokumen yang akan dijadikan sumber data sebagai landasan untuk melakukan analisis. Jurnal-jurnal, buku-buku dan dokumen-dokumen yang dikumpulkan yaitu berkaitan dengan pendidikan dan pembentukan karakter di sekolah. Langkah kedua yaitu kritik sumber. Kritik sumber dilakukan sebagai filter secara kritis dalam melakukan penilaian sumber menyangkut otentitas dan kepercayaan sumber. Kritik dilakukan melalui 2 (dua) tahap baik kritik intern (materi sumber) maupun kritik ekstern (subtansi atau isi). Langkah ketiga yaitu interpretasi (penafsiran) yaitu peneliti melakukan penafsiran terhadap sumbersumber data yang telah dikritik baik intern maupun ekstern, dan langkah keempat yaitu historiografi (penulisan) yaitu tahapan sintesis dari hasil penyeledikan sehingga pada akhirnya melahirkan tulisan yang utuh melalui proses rekonstruksi. Menurut Lois Gotsschalk, dalam Shofa, (2012) pada model penulisan (historiografi) menggunakan model deduktif. 


\section{HASIL DAN PEMBAHASAN}

Wilayah cakupan pengembangan karakter bangsa meliputi; (1) karakter merupakan hal sangat esensial dalam berbangsa dan bernegara, hilangnya karakter akan menyebabkan hilangnya generasi penerus bangsa; (2) karakter berperan sebagai "kemudi" dan kekuatan sehingga bangsa ini tidak terombangambing; (3) karakter tidak datang dengan sendirinya, tetapi harus dibangun dan dibentuk untuk menjadi bangsa yang bermartabat. Sedangkan fokus karakter bangsa yaitu; (1) untuk menumbuhkan dan memperkuat jati diri bangsa; (2) untuk menjaga keutuhan Negara Kesatuan Republik Indonesia (NKRI); dan (3) untuk membentuk manusia dan masyarakat Indonesia yang berakhlak mulia dan bangsa yang bermartabat.

Cakupan karakter bangsa tersebut sangat esensial, pembentukan karakter masyarakat sangat dibutuhkan oleh sebuah bangsa, terutama untuk kelangsungan hidup suatu bangsa, bahkan karakter tersebut dijadikan kemudi bagi suatu bangsa untuk melihat kearah mana bangsa di bangun sehingga menjadi bangsa yang bermartabat. Begitupun jika dilihat dari fokus karakter bangsa kita adalah membangun jatidiri bangsa dalam rangka memperkuat keutuhan Negara Kesatuan Republik Indonesia yang diisi oleh masyarakat yang memiliki akhlak mulia dan bermartabat.

Berdasarkan wilayah cakupan dan fokus pengembangan karakter bangsa, maka sesungguhnya subtansinya adalah karakterdapatdimaknaisebagaikehidupan berperilaku baik/penuh kebajikan, yakni berprilaku baik terhadap pihak lain (Tuhan Yang Maha Esa, manusia, dan alam semesta) dan terhadap diri sendiri. Kita cenderung melupakan the virtuous life atau kehidupan yang penuh kebajikan, termasuk di dalamnya self-oriented virtuous atau kebajikan terhadap diri sendiri, seperti self control and moderation atau pengendalian diri dan kesabaran; dan other-oriented virtuous atau kebajikan terhadap orang lain, seperti generousity and compassion atau kesediaan berbagi dan merasakan kebaikan (Hasnawi, dkk, 2010).

\section{Desain Pendidikan dan Pembentukan Karakter Bangsa}

Pendidikan karakter menurut pencetusnya yaitu FW Foester (18691966) dalam Jalaluddin, (2012:2) adalah reaksi atas kejumudan pedagogi natural Rousseauian dan instrumentalisme pedagogis Deweyan, serta pedagogi Puerocentris lewat perayaan atas spontanitas anak-anak yang mewarnai Eropa dan Amerika Serikat pada awal abad ke-19 kian dianggap tidak mencukupi lagi bagi formasi intelektual dan kultural seorang pribadi. Polemik anti positivis dan anti naturalis di Eropa awal abad ke19 merupakan gerakan pembebasan dari determinisme natural menuju dimensi spiritual, bergerak dari formasi personal dengan pendekatan psiko sosial menuju cita-cita humanism yang lebih integral dan pendidikan karakter inilah yang dianggap sebagai sebuah usaha untuk menghidupkan kembali pedagogi idealspritual yang sempat hilang diterjang gelombang positivisme ala Comte.

Mengingat begitu pentingnya karakter bangsa dibangun dan dikembangkan, maka dibuatlah desain pengembangan karakter, termasuk desain pendidikan karakter dalam rangka pembentukan karakter bangsa yang sesungguhnya sudah dimiliki sebagai jatidiri bangsa Indonesia. Menurut Thomas Lickona bahwa "Pendidikan karakter 
dapat dimaknai sebagai pendidikan nilai, pendidikan budi pekerti, pendidikan moral, pendidikan watak, yang bertujuan mengembangkan kemampuan peserta didik untuk memberikan keputusan baik-buruk, memelihara apa yang baik, dan mewujudkan kebaikan itu dalam kehidupan sehari-hari dengan sepenuh hati" (Udin, S. W., 2009). Pandangan Lickona tersebut, jika ditelusuri dalam sejarah perjalanan bangsa Indonesia, maka sesungguhnya telah lama menjadi bagian penting dalam pendidikan bangsa Indonesia. Lantas apa yang menjadi persoalan hingga dewasa ini, sehingga penting dikembangkan pendidikan karakter, ditengah kondisi bangsa Indonesia yang mulai melupakan karakter bangsanya yang berbudi, berwatak, bermoral.

Pendidikan karakter yang memiliki muatan-muatan karakter baik dan kuat (sifat, sikap, dan perilaku budi luhur, akhlak mulia) menjadi modal dasar pengembangan individu dan bangsa di masa depan. Daniel Goleman dalam bukunya Emotional Inteligence menyatakan betapa kepribadian manusia mendominasi 80 persen dari kehidupan seseorang, dibanding dengan 20 persen kecerdasan otaknya semata-mata. Para teknokrat di dunia barat sudah sadar bahwa betapa pun sebuah kemajuan dicapai, dapat menjadi perusak bila tidak dibekali dengan perimbangan karakter yang di dalamnya menggabungkan kaidah-kaidah etika, moral dan agama (Hasnawi, dkk, 2009).

Berpijak pada pernyataan William Franklin "Billy" Graham Jr. salah seorang rohaniawan terkemuka Amerika Serikat yang mengatakan, "When wealth is lost, nothing is lost. When health is lost, something is lost. When character is lost, everything is lost". (Bila kekayaan hilang, belum ada sesuatu yang hilang. Bila kesehatan hilang, barulah ada sesuatu yang hilang. Bila karakter hilang, berarti segalanya hilang) (Patahuddin, 2009).

Lebih lanjut dinyatakan bahwa pendidikan karakter sebagai usaha untuk mencegah tumbuhnya sifat-sifat buruk yang bisa menutupi fitrah manusia, serta melatih anak untuk terus melakukan perbuatan baik sehingga mengakar kuat dalam dirinya sehingga akan tercermin dalam tindakannya yang senantiasa melakukan kebajikan. Pentingnya membangun perilaku karakter dalam pendidikan, karena perilaku karakter dapat;

1. Menanamkan rasa cinta pada Tuhan dan kebenaran.

2. Menumbuhkan sikap tanggung jawab, kedisiplinan dan kemandirian.

3. Menumbuhkan sikap amanah dan kejujuran.

4. Menumbuhkembangkan rasa hormat dan santun.

5. Mengembangkan sikap kasih sayang, kepedulian dan kerja sama.

6. Menumbuhkan rasa percaya diri, kreatif dan pantang menyerah.

7. Membangun sikap keadilan dan kepemimpinan.

8. Menumbuhkan sikap baik dan rendah hati.

9. Membangun dan menumbuhkan sikap toleransi dan cinta damai (Megawangi, 2004).

Berdasarkan berbagai bangunan karakter tersebut, juga diperlukan kreativitas untuk mengembangkan karakter sebab manusia yang berkarakter 
baik dan unggul menjadi pilar penunjang dalam pembangunan yang berkarakter pula. Terdapat sembilan pilar pendidikan karakter yang saling terkait, yaitu: responsibility (tanggung jawab); respect (rasa hormat); fairness (keadilan); courage (keberanian); honesty (kejujuran); citizenship (kewarganegaraan. Manusia yang ulet belum tentu gigih, karena itu perlu diberi perhatian juga. Manusia yang gigih, tidak pantang menyerah, dan selalu berusaha dengan berbagai cara dalam koridor yang dapat dipertanggung jawabkan harus menjadi ciri dari karakter bangsa Indonesia. Dengan manusia Indonesia yang berkarakter, gigih, ulet dan kreatif seperti itu diharapkan akan mampu mengejar ketertinggalannya dari negara lain yang telah maju (Suratno, 2009).

Thomas Lickona seorang profesor pendidikan dari Cortland University mengungkapkan bahwa ada sepuluh tanda-tanda jaman yang harus diwaspadai karena jika tanda-tanda ini sudah ada, maka itu berarti bahwa sebuah bangsa sedang menuju jurang kehancuran. Adapun tanda-tanda yang dimaksud adalah:

1. Meningkatnya kekerasan di kalangan remaja,

2. Penggunaan bahasa dan kata-kata yang memburuk,

3. Pengaruh peer-group yang kuat dalam tindak kekerasan,

4. Meningkatnya perilaku merusak diri, seperti penggunaan narkoba, alkohol dan seks bebas.

5. Semakin kaburnya pedoman moral baik dan buruk,

6. Menurunnya etos kerja,

7. Semakin rendahnya rasa hormat kepada orang tua dan guru,

8. Rendahnya rasa tanggung jawab individu dan warga negara,

9. Membudayanya ketidakjujuran, dan

10. Adanya rasa saling curiga dan kebencian di antara sesama.

Proses pengembangan dan pembentukan karakter bangsa yang dikemukakan lebih mengacu pada desain induk pendidikan karakter yang dikembangkan oleh Kementerian Pendidikan Nasional (2010) dan berbagai pandangan yang dikemukakan oleh Udin Sarifuddin Winataputera (2009). Secara makro pengembangan karakter dapat dibagi dalam tiga tahap, yakni perencanaan, pelaksanaan, dan evaluasi hasil. Pada tahap perencanaan dikembangkan perangkat karakter yang digali, dikristalisasikan, dan dirumuskan dengan menggunakan berbagai sumber, antara lain pertimbangan: (1) filosofisAgama, Pancasila, UUD1945, dan UUN0.20 Tahun 2003 beserta ketentuan perundangundangan turunannya; (2) pertimbangan teoretis-teori tentang otak (brain theories), psikologis (cognitive development theories, learning theories, theories of personality) pendidikan (theories of instruction, educational management, curriculum theories), nilai dan moral (axiology, moral development theories), dan sosial-kultural (school culture, civic culture); dan (3) pertimbangan empiris berupa pengalaman dan praktek terbaik (best practices) dari antara lain tokoh-tokoh, satuan pendidikan unggulan, pesanren, kelompok kultural dan lain-lain.

Tahap implementasi dikembangkan pengalaman belajar (learning experiences) dan proses pembelajaran yang bermuara pada pembentukan karakter dalam diri individu peserta didik. Proses ini dilaksanakan melalui proses pembudayaan 
dan pemberdayaan. Proses ini berlangsung dalam tiga pilar pendidikan yakni dalam satuan pendidikan, keluarga, dan masyarakat. Dalam masing-masing pilar pendidikan akan ada dua jenis pengalaman belajar (learning experiences) yang dibangun melalui dua pendekatan yakni intervensi dan habituasi. Agar proses pembelajaran tersebut berhasil maka peran guru sebagai sosok panutan (role model) sangat penting dan menentukan. Sementara itu dalam habituasi diciptakan situasi dan kondisi (persistent-life situation), dan penguatan (reinforcement) yang memungkinkan peserta didik pada satuan pendidikannya, dirumahnya, di lingkungan masyarakatnya membiasakan diri berperilaku sesuai nilai dan menjadi karakter yang telah diinternalisasi dan dipersonalisai dari dan melalui proses intervensi.

Dalam kehidupan berbangsa dan bernegara, pelaksanaan pendidikan karakter harus teraplikasi pada semua sektor kehidupan, bukan hanya sektor pendidikan, namun juga pada sektor lainnya, misalnya keagamaan, kesejahteraan, pemerintahan, komunikasi dan informasi, kesehatan, hukum dan hak azasi manusia, serta pemuda dan olah raga.

Pada tahap evaluasi hasil, dilakukan asesmen program untuk perbaikan berkelanjutan yang sengaja dirancang dan dilaksanakan untuk mendeteksi aktualisasi karakter dalam diri peserta didik sebagai indikator bahwa proses pembudayaan dan pemberdayaan karakter itu berhasil dengan baik.

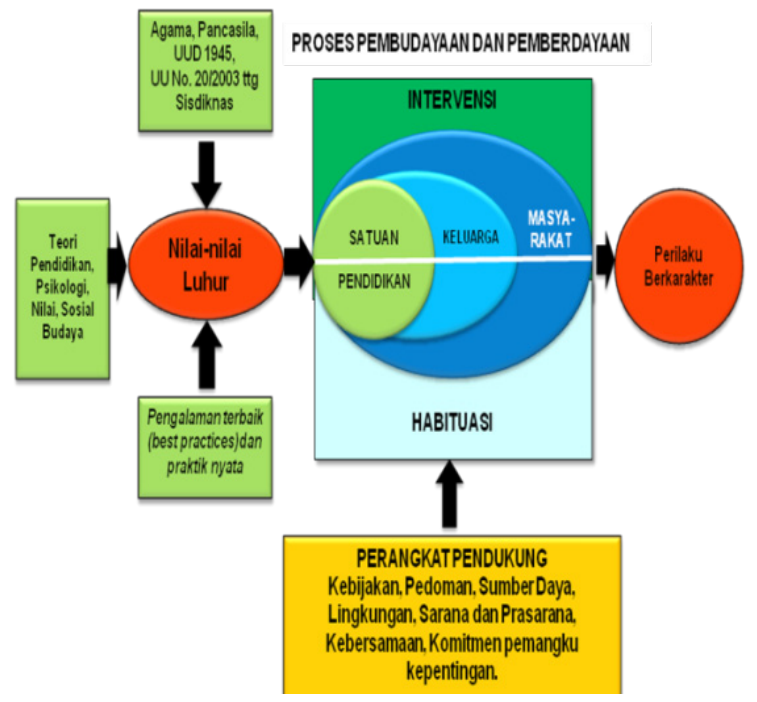

Secara mikro pengembangan nilai/ karakter dapat dibagi dalam empat pilar, yakni kegiatan belajar-mengajar di kelas, kegiatan keseharian dalam bentuk budaya satuan pendidikan (school culture); kegiatan ko-kurikuler dan/atau ekstra kurikuler, serta kegiatan keseharian di rumah, dan dalam masyarakat.

Dalam kegiatan belajar-mengajar di kelas pengembangan nilai/karakter dilaksanakan dengan menggunakan pendekatan terintegrasi dalam semua mata pelajaran (embeded approach). Strategi/ metode pendidikan nilai (value/character education). Nilai/karakter dikembangkan sebagai dampak pembelajaran (instructional effects) dan juga dampak pengiring (nurturant effects). Secara formal memiliki misi utama selain pengembangan nilai/ karakter, wajib dikembangkan kegiatan yang memiliki dampak pengiring (nurturant effects) berkembangnya nilai/ karakter dalam diri peserta didik.

Dalam lingkungan satuan pendidikan dikondisikan agar lingkungan fisik dan sosial-kultural satuan pendidikan memungkinkan para peserta didik bersama dengan warga satuan pendidikan lainnya terbiasa membangun kegiatan keseharian 
di satuan pendidikan yang mencerminkan perwujudan nilai/karakter.

Dalam kegiatan ko-kurikuler, yakni kegiatan belajar di luar kelas yang terkait langsung pada suatu materi dari suatu mata pelajaran, atau kegiatan ekstra kurikuler, yakni kegiatan satuan pendidikan yang bersifat umum dan tidak terkait langsung pada suatu mata pelajaran, seperti kegiatan Dokter Kecil, Palang Merah Remaja, Pecinta Alam dan lain-lain, perlu dikembangkan proses pembiasaan dan penguatan (reinforcement) dalam rangka pengembangan nilai/karakter.

Di lingkungan keluarga dan masyarakat diupayakan agar terjadi proses penguatan dari orang tua/wali serta tokoh-tokoh masyarakat terhadap prilaku berkarakter mulia yang dikembangkan di satuan pendidikan menjadi kegiatan keseharian di rumah dan di lingkungan masyarakat masing-masing.

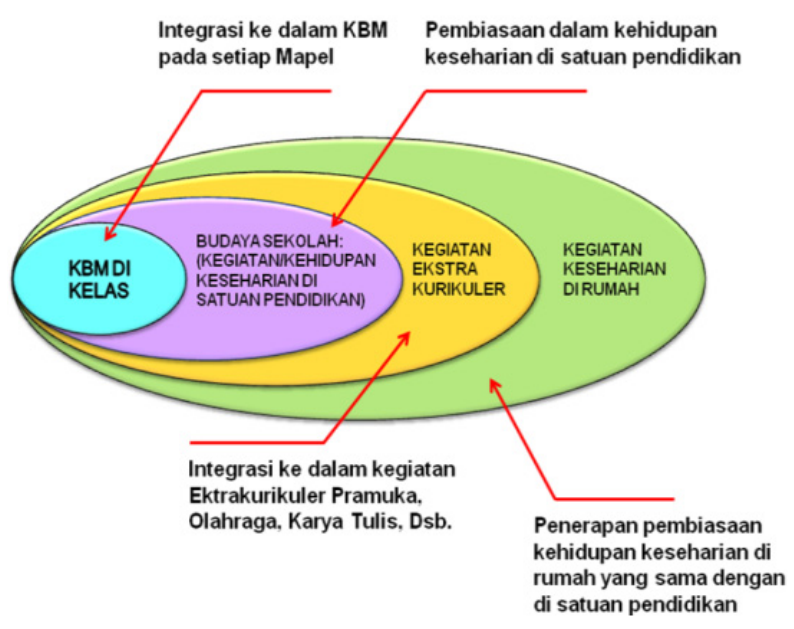

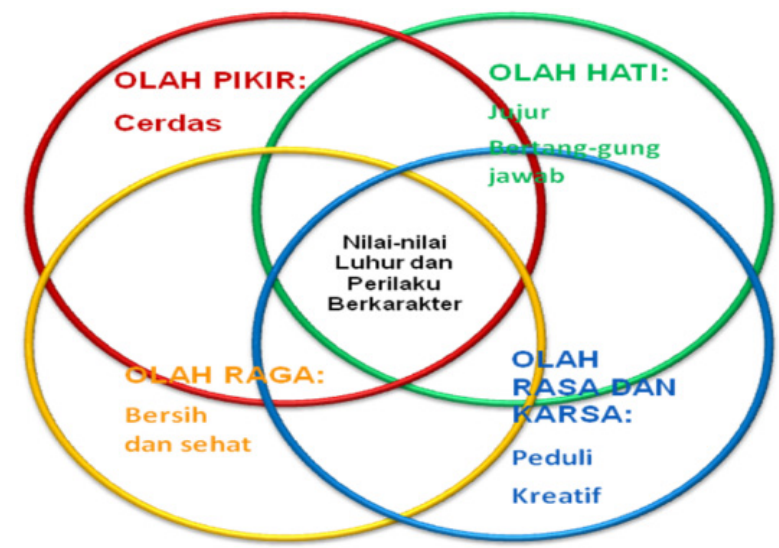

Pembentukan karakter bangsa, membutuhkan keunggulan-keunggulan dari warga Negara, baik dari sisi olah pikir (kecerdasan), olah hati (jujur dan bertanggunjawab); olah raga (bersih dan sehat) serta olah rasa dan karsa (peduli dan kreatif) yang dibungkus oleh nilai-nilai luhur dan perilaku yang berkarakter yang dimiliki oleh bangsa Indonesia. Secara psikologis dan sosial kultural pembentukan karakter dalam diri individu merupakan fungsi dari seluruh potensi individu manusia (kognitif, afektif, konatif, dan psikomotorik) dalam konteks interaksi sosial kultural (dalam keluarga, satuan pendidikan, dan masyarakat) dan berlangsung sepanjang hayat.

\section{Pendidikan dan Pembentukan Karakter di Sekolah}

Sebagaimana disebutkan sebelumnya dalam pembentukan karakter bangsa, dimulai dalam lingkungan keluarga, satuan pendidikan, dan masyarakat. Pada bagian ini diutarakan bagaimana pentingnya pendidikan dan pembentukan karakter di sekolah dan bagaimana cara mengintegrasikannya dalam pembelajaran di sekolah. Meskipun sebenarnya pendidikan dan pembentukan karakter harus dibangkitkan pada semua level kehidupan, namun pada kesempatan ini peneliti membantasi pada jenjang atau level kehidupan sekolah. 
Menurut Lickona (1992) bahwa terdapat 11 (Sebelas) faktor yang dapat menentukan keberhasilan pendidikan karakter di satuan pendidikan (sekolah), yaitu (1) pendidikan karakter harus mengandung nilai-nilai yang dapat membentuk good character, (2) karakter harus didefinisikan secara menyeluruh yang termasuk aspek thingking, feeling, dan action, (3) pendidikan karakter yang efektif memerlukan pendekatan yang komprehensif dan terfokus kepada guru sebagai role model, (4) sekolah harus menjadi model masyarakat yang damai dan harmonis, (5) sekolah harus memberikan kesempatan kepada siswa untuk mempraktekkan perilaku moral, (6) pendidikan karakter yang efektif harus mengikutsertakan materi kurikulum yang berarti bagi kehidupan anak atau berbasis kompetensi, (7) pendidikan karakter harus membangkitkan motivasi internal dari diri anak, (8) sejumlah staf sekolah harus terlibat dalam pendidikan karakter, (9) pendidikan karakter di sekolah mememrlukan kepemimpinan moral dari berbagai pihak, pimpinan, staf dan para guru, (10) sekolah harus bekerja sama dengan orang tua siswa dan masyarakat sekitarnya, dan (11) harus ada evaluasi berkala mengenai keberhasilan pendidikan karakter di sekolah.

Pandangan Lickona

kemudian disandingkan dengan penerapan pendidikan karakter di sekolah (Kemendiknas, 2010) yaitu (1) mempromosikan nilai-nilai dasar etika sebagai basis karakter, (2) mengidentifikasi karakter secara komprhensif supaya mencakup pemikiran, perasaan, dan perilaku, (3) menggunakan pendekatan yang tajam, proaktif dan efektif untuk membangun karakter, (4) menciptakan komunitas sekolah yang memiliki kepedulian, (5) memiliki cakupan terhadap kurikulum yang bermakna dan menantang yang menghargai semua peserta didik, membangun karakter mereka, dan membantu mereka untuk sukses, (6) mengusahakan tumbuhnya motivasi diri pada peserta didik, (7) menfungsikan seluruh staf sekolah sebagai komunitas moral yang berbagi tanggungjawab untuk pendidikan karakter dan setia pada nilai dasar yang sama, (8) adanya pembagian kepemimpinan moral dan dukungan luas dalam membangun inisiatif pendidikan karakter, (9) menfungsikan keluarga dan anggota masyarakat sebagai mitra dalam usaha membangun karakter, (10) mengevaluasi karakter sekolah, fungsi staf sekolah sebagai guru-guru karakter, dan manifestasi karakter positif dalam kehidupan peserta didik.

Sementara itu, Character Education Quality Standards merekomendasikan 11 (sebelas) prinsip untuk mewujudkan pendidikan karakter yang efektif yaitu (1) mempromosikan nilai-nilai dasar sebagai basis karakter, (2) mengidentifikasi karakter secara komprehensif supaya mencakup pemikiran, perasaan dan perilaku, (3) menggunakan pendekatan yang tajam, proaktif dan efektif untuk membangun karakter, (4) menciptakan komunitas sekolah yang memiliki kepedulian, (5) memberi kesempatan kepada siswa untuk menunjukkan perilaku yang baik, (6) memliki cakupan terhadap kurikulum yang bermakna dan menantang yang menghargai semua siswa, membangun karakter mereka dan membantu mereka untuk sukses, (7) mengusahakan tumbuhnya motivasi diri dan para siswa, (8) memfungsikan seluruh staf sekolah sebagai komunitas moral yang berbagi tanggungjawab untuk pendidikan karakter dan setia pada nilai dasar yang sama, (9) adanya pembagian kepemimpinan moral dan dukungan luas 
dalam membangun inisiatif pendidikan karakter, (10) memfungsikan keluarga dan anggota masyarakat sebagai mitra dalam usaha membangun karakter, (11) mengevaluasi karakter sekolah, fungsi staf sekolah sebagai guru-guru karakter, dan manifestasi karakter positif dalam kehidupan siswa (Ainusyamsi; tanpa tahun).

Ketiga pandangan untuk penerapan pendidikan karakter tersebut, baik menurut Lickona, Kemendiknas, dan Character Education Quality Standards, memiliki muatan yang hampir sama dan penekanan pada pentingnya pendidikan karakter dibangun di sekolah, dengan berfokus pada pendidikan nilai, keterlibatan sekolah baik staf, guru, dan segenap unsur terkait dengan mengintegrasikan pendidikan karakter dalam aktivitas sekolah.

Optimalisasi pendidikan karakter menurut Jamal (2011) dalam Saripuddin dapat dilakukan: Pertama, pendidikan karakter secara terpadu melalui pembelajaran, kedua, pendidikan karakter secara terpadu melalui manajemen sekolah, ketiga, pendidikana karakter secara terpadu melalui kegiatan ekstrakurikuler. Optimalisasi pertama dilakukan melalui pengenalan nilai untuk terwujudnya kesadaran akan pentingnya nilai-nilai, dan internalisasi nilai ke dalam tingkah laku peserta didik sehari-hari melalui proses pembelajaran yang berlangsung di dalam dan di luar kelas. Optimalisasi kedua, harus dikelola melalui manajemen sekolah melaluitahapan perencanaan, pelaksanaan, dan pengendalian. Nilai-nilai yang diintegrasikan dalam manajemen sekolah adalah nilai-nilai karakter kompetensi lulusan, muatan dalam pembelajaran, nilainilai karakter pembinaan peserta didik. Model penerapan manajemen sekolah untuk pendidikan karakter yaitu bersifat partisipatif, demokratis, elaborative, dan eksploratif, sehingga dapat dirasakan secara bersama. Optimalisasi ketiga yaitu melalui kegiatan ekstrakurikuler didesain sedemikian rupa maka akan menjadi wahana efektif pembentukan karakter berbasis potensi diri.

Pendekatan penanaman nilai pada pendidikan karakter memberikan penekanan pada penanaman nilai-nilai sosial dan budaya pada diri peserta didik. Pendidikan nilai berupa penanaman nilainilai sosial budaya pada peserta didik adalah upaya penanaman nilai-nilai sosial budaya tertentu kepada peserta didik sehingga dapat merubah nilai-nilai sosial dan budaya peserta didik yang tidak sesuai dengan nilai-nilai sosial budaya yang ada pada bangsanya. Olehnya itu dalam proses pengintegrasian penanaman nilainilai sosial budaya tersebut dibutuhkan keteladanan, permainan peran, penguatan positif dengan menggunakan model pendekatan partisipatif, demokratis, elaborative, hingga dapat melakukan eksplorasi terhadap nilai-nilai sosial budaya peserta didik, sehingga tertanam nilai-nilai sosial budaya yang fungsional.

Selain itu, di lingkungan sekolah dibutuhkan pendidikan karakter dengan menggunakan pendekatan analisis nilai yang memberikan penekanan pada perkembangan kemampuan siswa untuk dapat berpikir secara logis, dengan cara menganalisis masalah yang berhubungan dengan nilai-nilai sosial dan budaya. Hingga akhirnya pendidikan karakter dengan melakukan pendekatan klarifikasi nilai dapat membantu peserta didik dalam mengkaji perasaan dan perbuatannya sendiri untuk meningkatkan kesadaran mereka tentang nilai-nilai mereka sendiri. 


\section{KESIMPULAN}

Pada bagian penutup, diutarakan begitu pentingnya pendidikan karakter bangsa dibangun dan dikembangkan sehingga dalam implementasi kehidupan berbangsa dan bernegara senantiasa dilandasi oleh nilai-nilai karakter. Karakter bangsa tidak hanya menjadi tanggungjawab bangsa tetapi telah menjadi tanggungjawab seluruh warga bangsa untuk bersama-sama membangun bangsa. Meminjam istilah yang dikembangkan oleh Kementerian Pendidikan dan Kebudayaan Republik Indonesia dalam sebuah konsep dan program "Maju Bersama" mencerdaskan bangsa, mengandung filosofi yang sangat dalam bahwa salah satunya cara untuk membangun bangsa Indonesia adalah kita harus maju bersama dengan keragaman karakter yang baik untuk membangun bangsa yang kita cintai ini. Pendidikan karakter lahir sebagai reaksi atas kejumudan pedagogi natural ala Rousseuain dan instrumentalisme pedagogi Deweyan pada abad ke-19 yang dianggap tidak lagi mencukupi untuk formasi intelektual dan buday seorang pribadi yang kemudian melahirkan gerakan pembebasan dari determinisme natural menuju dimensi spiritual dengan pendekatan psiko-sosial menuju cita-cita humanism yang lebih integral.

Pendidikan dan pembentukan karakter di sekolah merupakan suatu keharusan dalam rangka penanaman nilainilai sosial dan budaya karakter peserta didik, sehingga peserta didik memiliki karakter yang sesuai dengan karakter yang dimiliki oleh bangsa Indonesia. Olehnya itu dibutuhkan pengintegrasian pendidikan karakter dalam pembelajaran, manajemen sekolah dan kegiatan terpadu ekstrakurikuler dengan menggunakan model pendekatan partisipatif, demokratis, elaboratif, dan eksploratif, sehingga tertanam nilai-nilai sosial budaya dalam diri peserta didik. Pendidikan karakter di sekolah juga dapat dilakukan melalui pendekatan penananan nilai, analisis nilai, dan klarifikasi nilai yang dapat membantu peserta didik untuk mengenali dirinya.

\section{Daftar Pustaka}

Ainusyamsi, Pendidikan Karakter di Jepang. Makalah. Universitas Pendidikan Bandung.

Haris, Hasnawi, dkk. 2010. Menjadi Tau Tongeng (Insan Kamil); Model Pendidikan Karakter Universitas Negeri Makassar. Universitas Negeri Makassar dan Kementerian Pendidikan Nasional. Makassar.

Hariyono, 1995. Mempelajari Sejarah Secara Efektif. Jakarta: Pustaka Jaya.

Jalaluddin, 2012. Membangun SDM melalui Pendidikan Karakter. Jurnal Penelitian Pendidikan, Vol. 13. No. 2 Oktober 2012.

Lickona, Thomas, 1992. Education for Character, How Our Schools Can Teach Respect and Responsibility. New York: Bantam Books.

Megawangi, Ratna, 2004. Pendidikan Karakter Solusi yang Tepat untuk Membangun Bangsa. IHF. Jakarta.

Patahuddin, 2009. Membangun Karakter Bangsa Melalui Penanaman Aspek-Aspek Kearifan Lokal Bugis-Makassar. Makalah Seminar Internasional. Makassar.

Republik Indonesia, 2010. Disain Induk Pendidikan Karakter. Kemdiknas; Jakarta.

Republik Indonesia, 2010. Pembinaan Pendidikan Karakter di Sekolah Menengah Pertama. Jakarta.

Shofa, Abd. Mu,id Aris, 2012. Pendidikan Karakter di Sekolah Sejak Proklamasi 
Kemerdekaan Sampai Era Reformasi

Universitas Negeri Malang, Malang.

Syarifuddin, Wahyu, Optimalisasi Implementasi

Pendidikan Karakter Menuju Bangsa

Indonesia yang Lebih Baik. Esai Seleksi

Lomba Debat Aspirasi Untuk Negeri

Debat TV One.

Suratno, 2009. Kreativitas, Pendidikan Ilmu

Pengetahuan Sosial dan Pendidikan

Karakter Bangsa. Makalah Seminar

Internasional. Makassar.

Winataputera, Udin Saripuddin, 2009. Peran

Pendidikan Ilmu Pengetahuan Sosial

(PIPS) dalam Konteks Pembangunan

Karakter Bangsa (Kebijakan, Konsep,

dan Kerangka Programatik). Makalah

yang disajikan dalam Seminar

Internasional. Makassar.

Zulnuraini, 2012. Pendidikan Karakter;

Konsep, Implementasi dan

Pengembangannya di Sekolah Dasar di

Kota Palu. Jurnal DIKDAS, No. 1, Vol. 1,

September 2012. 


\title{
Paradigma dalam Pembelajaran Sejarah Kontroversi
}

\author{
Oleh : Sumardiansyah \\ Pendidikan Sejarah PPS UNJ
}

\begin{abstract}
After the fallen of the new order era, social-political structures has been supporting the born of new claims or interpretations towards the so-called-and-believed history. Some historical themes have been discussed, reviewed and re-narrated in new interpretation and perspective. This is marked with the issuance of new books, the emergence of new ideas, as well as findings of recent facts and data. This phenomenon has emerged with its pro and contra among historians, teachers and general society, then later leads to a new found term as controversial history.

This article aims to discuss the paradigm of learning the controversial history study, that includes what is controversial history study itself, the urgency of historical learning, as well as models, approaches, and strategies used by teachers in the face of controversial history learning. Controversial history is an interesting theme in classroom history learning since it can stimulates learners to practice their logical, critical, and creative thinking. Full understanding and in-depth material for a history teacher is absolutely necessary here, other than the ability to manage learning in didactic-methodical. Research based methods used a qualitative approach, in which the resources obtained throught literature review.
\end{abstract}

Keywords: Controversial history, history learning, teacher, learners, historians

\begin{abstract}
Abstrak
Pasca runtuhnya rezim orde baru, struktur sosial-politis mendukung lahirnya gugatan maupun tafsirtafsir baru terhadap peristiwa sejarah yang selama ini diyakini. Beberapa tema sejarah dibahas, dikaji, dan dinarasikan kembali dalam tafsir dan perspektif baru. Hal ini ditandai dengan terbitnya buku-buku baru, munculnya gagasan-gagasan baru, serta ditemukannya data dan fakta baru. Fenomena ini menjadi pro dan kontra di kalangan sejarawan, guru, bahkan masyarakat pada umumnya, yang kemudian melahirkan istilah baru yaitu sejarah kontroversi.

Tulisan ini bertujuan membahas mengenai paradigma pembelajaran sejarah kontroversi yang mencakup apa itu pembelajaran sejarah kontroversi, urgensinya dalam pembelajaran sejarah, serta model, pendekatan dan strategi yang digunakan guru dalam menghadapi pembelajaran sejarah kontroversi. Sejarah kontroversi merupakan tema yang menarik dalam pembelajaran sejarah di kelas, karena diharapkan mampu merangsang peserta didik untuk berpikir logis, kritis, dan kreatif. Pemahaman materi yang utuh dan mendalam bagi seorang guru sejarah mutlak diperlukan di sini, selain daripada kemampuan untuk mengelola pembelajaran secara didaktik-metodik. Metode penelitian menggunakan pendekatan kualitatif, dimana sumber-sumber diperoleh melalui studi pustaka.
\end{abstract}

Kata kunci: sejarah kontroversi, pembelajaran sejarah, guru, peserta didik, sejarawan 


\section{PENDAHULUAN}

Tahun 1998 seiring runtuhnya rezim orde baru, menjadi tonggak awal bermunculannya gugatan masyarakat terhadap sejarah. Pemerintah orde baru dianggap menjadikan sejarah sebagai legitimasi kekuasaan. Istilah ini kemudian dikenal dengan "sejarah resmi, versi pemerintah". Lahirnya gugatan terhadap sejarah jika dilihat dari struktur sosialpolitis pada saat itu setidaknya dipicu oleh tiga hal yaitu, (1) sudah tidak adanya sosok yang dianggap diktator (dalam wujud Jenderal Suharto); (2) sistem perundangundangan yang mendukung (UU No. 9 Tahun 1998 mengenai kemerdekaan menyampaikan pendapat di muka umum); (3) keterbukaan arus informasi yang deras di masyarakat. Implikasinya ialah setiap orang bebas untuk menyampaikan pendapat dan kritik, baik secara lisan maupun tulisan, termasuk membahas persoalan sejarah di dalamnya.

Dari sisi keilmuan gugatan yang muncul terhadap sejarah resmi versi pemerintah, sejalan dengan isu yang diusung oleh kelompok Annales, kelompok ini berupaya menawarkan sejarah dalam perspektif baru atau sejarah alternative (Asvi Warman Adam, 2005: xxx). Pembaharuan yang dimaksud ialah pembaharuan dalam hal sumber, metodologi dan perspektif. Sebelumnya para pengikut Ranke cenderung memandang bahwa satu-satunya sumber terpercaya dalam penelitian sejarah adalah dokumen tertulis, istilah yang dikenal dengan ungkapan "no written document no history".

Dalam halini Ranke dan pengikutnya mengabaikan, bahwa sesungguhnya ada sumber-sumber lain (misal foto, video, artefak, termasuk kesaksian seseorang) yang dapat dijadikan rujukan untuk penelitian sejarah dan harus diingat bahwa tidak semua manusia, bangsa, ataupun masyarakat memiliki tradisi tertulis di dalam menyimpankenangan masalalunya. Sebagian besar justru lebih mengandalkan memori atau ingatan di dalam menyimpan atau mengkomunikasikan hal-hal yang berkaitan dengan kenangan masa lalunya, inilah yang kemudian mempopulerkan metode oral history di dalam proses pengumpulan sumber sejarah.

Dari segi perspektif, sejarah tidak hanya ditulis dari perspektif pemenang, melainkan juga bisa ditulis oleh perspektif korban (pihak yang kalah), sejarah tidak saja berbicara mengenai peran orangorang besar (penguasa) melainkan rakyat juga bisa berperan di dalamnya. Penggunaan teori-teori ilmu sosial dianggap mampu mempertajam analisa di dalam mengkaji sebuah peristiwa sejarah. Berangkat dari fenomena dan dinamika inilah (terbitnya buku-buku baru, bermunculannya gagasan-gagasan baru, bahkan dalam beberapa kasus ditemukan data dan fakta baru) yang kemudian melahirkan istilah sejarah kontroversial. Kontroversi dalam sejarah disebabkan oleh fakta dan interpretasi yang: (1) tidak tepat; (2) tidak lengkap; (3) tidak jelas (Asvi Warman Adam, 2007: 1). Perlu di tekankan istilah kontroversi sebenarnya berkaitan erat dengan interpretasi atau narasi yang diceritakan dalam sebuah peristiwa sejarah, yang tentunya interpretasi atau narasi ini berkaitan erat dengan kepentingan ideologis, politis, dan pragmatis dari sekelompok orang (penguasa maupun bukan penguasa).

Di ranah pendidikan pada tingkat Sekolah Menengah Atas, sejarah dipelajari dalam sebuah mata pelajaran yang berdiri sendiri. Hal berbeda jika melihat 
pembelajaran sejarah pada tingkat Sekolah Dasar dan Sekolah Menengah Pertama, dimana sejarah merupakan bagian dari Ilmu Pengetahuan Sosial, sejarah diajarkan secara terpadu berbarengan dengan geografi, ekonomi, dan sosiologi. Pembelajaran sejarah diharapkan mampu membentuk nation and character building, serta membentuk karakter positif di dalam diri peserta didik. Selain itu apabila dicermati lebih mendalam, belajar sejarah juga mampu membentuk pola pikir peserta didik agar menjadi logis, kritis dan kreatif.

Peristiwa sejarah yang terjadi di masa lampau tentunya memiliki jarak dengan masa sekarang, dengan situasi sosial, politik, lingkungan, atau jiwa zaman yang mungkin saja berbeda. Melihat kenyataan ini tentu dibutuhkan kemampuan berpikir tingkat tinggi (nalar dan imajinasi), sehingga peserta didik mampu membangun "jembatan" yang bisa menghubungkan antara masa lampau dengan masa sekarang. Namun melihat realitas di lapangan, pembelajaran sejarah sesungguhnya menghadapi banyak hambatan dan tantangan. Guru dalam melaksanakan pembelajaran masih lemah dalam hal penggunaan teori, miskinnya imajinasi, buku teks dan kurikulum yang cenderung state oriented, serta kecenderungan untuk tidak memperhatikan fenomena globalisasi berikut latar belakang historisnya (Y.R. Subakti, 2010: 3-4).

\section{METODE PENELITIAN}

Penelitian ini menggunakan pendekatan kualitatif. Pendekatan kualitatif menurut Emzir (2011: 28) ialah pendekatan yang secara primer menggunakan paradigma pengetahuan berdasarkan pandangan konstruktivis (misal makna jamak dari pengalaman individu atau makna yang dibangun untuk mengembangkan suatu teori atau pola) dan pandangan advokasi atau partisipatori (misal orientasi pendidikan, isu, kolaboratif, atau orientasi perubahan).

Sumber-sumber diperoleh melalui studi pustaka yang disajikan dalam pendahuluan untuk menjelaskan kerangka teoretis-kronologis masalah penelitian (Creswell, 2010: 43). Studi pustaka adalah teknik pengumpulan data dengan menelaah buku-buku, literatur-literatur, catatan-catatan, dan laporan-laporan yang ada keterkaitannya dengan masalah yang akan di bahas atau di teliti (Nazir, 1998: 112).

\section{HASIL DAN PEMBAHASAN}

\section{Pembelajaran Sejarah Kontroversi}

Pembelajaran sejarah kontroversi merupakan upaya, pendekatan, maupun strategi guru untuk membahas tema atau isu-isu kontroversi dalam pembelajaran sejarah di kelas. Bertolak dari pemikiran bahwa ilmu sejarah itu bersifat "terbuka" dan "dinamis", maka menghadirkan masa lalu dalam beragam perspektif secara berimbang merupakan hal yang penting. Pembahasan isu kontroversi dalam sejarah akan berusaha menghilangkan dimensi kebenaran mutlak tanpa diimbangi dengan pembuktian sejarah (Elly, 2008: 138-139).

Tanggal 12-13 Mei 1999 dalam dialog pengajaran sejarah di Wisma Yayasan Tenaga Kerja Indonesia, Jakarta, terungkap informasi dari para guru mengenai tema-tema dalam sejarah yang dipertanyakan kredibilitasnya, antara lain: 1) Lahirnya Pancasila; 2) Serangan Umum 
Satu Maret 1949; 3) Posisi Sukarno dan Suharto dalam Gerakan 30 September 1965; 4) Supersemar; 5) Integrasi TimorTimur; 6) Kasus Perang Gowa Sultan Hasanudin-Aru Palaka; 7) Menempatkan Kasus-Kasus Pemerintahan Daerah; 8) Persoalan Esensial dari Peristiwa Sejarah yang Terlupakan seperti: PDRI, RMS, Hatta-Syahrir, Tan Malaka, dan sebagainya (Sri Sjamsiar dan Fakhruddin, 1999: 4).

Pada prinsipnya tema atau isuisu kontroversi merupakan bagian dari sebuah teks sejarah. Teks yang ada tidak terlepas dari penafsiran pihak-pihak yang membaca ataupun berkepentingan dengan teks tersebut. Sebagaimana dinyatakan dalam teori independensi teks, bahwa setiap pengetahuan yang sudah diumumkan akan masuk ke dalam ranah pengetahuan objektif. Di mana teks akan memiliki sifat "otonom", terlepas dari monopoli pengarang atau penggagasnya, sehingga dalam hal penafsiran tidak lagi bergantung pada pengarang atau penggagasnya (Popper dalam Kasemin, 2003: 10). Implikasinya adalah, tafsiran terhadap suatu teks ataupun pendapat yang sudah diumumkan, bisa saja berbeda dari tujuan semula sebagaimana diniatkan dan dimaksudkan oleh pengarang atau penggagasnya.

Di dalam ilmu sejarah dikenal adagium "interpretasi boleh saja keliru atau salah, akan tetapi kekeliruan atau kesalahan dalam hal sumber-sumber sejarah (data dan fakta) tidak boleh terjadi". Perbedaan penafsiran atau bahkan kekeliruan yang mungkin terjadi di dalam menafsirkan sebuah peristiwa sejarah bisa diabaikan di sini, sedangkan keberadaan dan kebenaran akan sumber merupakan "harga mati" yang tidak dapat ditawar-tawar kembali. Guru sejarah setidaknya mampu mengajarkan kepada peserta didik mengenai konsep independensi teks di dalam menafsirkan sebuah teks. Persoalannya adalah bukan pada benar atau tidaknya tafsir yang diberikan oleh peserta didik, melainkan argumentasi yang dijadikan landasan dalam memberikan penafsiran serta kedekatannya dengan fenomena yang terjadi dan berkaitan dengan teks tersebut. Guru sejarah juga wajib mengajarkan pengetahuan dan keterampilan akan sumber-sumber sejarah, sehingga peserta didik memiliki pemahaman yang utuh, bahwa penafsiran mengenai fenomena maupun peristiwa sejarah sudah sepatutnya dibangun dengan berpijak dari sumber-sumber yang ada.

Pemahaman kompetensi guru baik dari segi keilmuan maupun pedagogik sangat diperlukan. Pengetahuan yang dalam akan ilmu sejarah, membuat kita mampu menyampaikan sebuah gagasan, ataupun menceritakan sebuah peristiwa dengan didukung landasan keilmuan yang kuat (dibuktikan dengan argumen, data, fakta, dan referensi yang cukup). Guru juga harus mampu menguasai keterampilan pedagogik, ini akan bermanfaat di dalam menyampaikan gagasan ataupun peristiwa sejarah (guru tidak hanya ceramah secara monoton), tetapi mampu mengkolaborasikan teknik-teknik yang ada dalam metode pembelajaran (misal metode diskusi ataupun pendekatan konstruktivis).

Guru sejarah tidak boleh bersifat kaku dengan memberikan informasi antiquariat, dengan nilai-nilai yang sudah lapuk, yang memicu keringnya pemahaman pesertadidikdalamkesadaran sejarah kekinian (Dadang Supardan, 2011: 266). Pandangan ini diperkuat oleh penelitian Sheldon F. Shaffer tahun 19771978, berlokasi di Malang dengan subjek penelitian guru dan siswa, didapatkan 
fakta bahwa nilai-nilai budaya yang disampaikan lewat pendidikan, bukan nilai-nilai budaya yang diperlukan oleh peserta didik setelah dewasa kelak. Nilainilai yang diberikan justru nilai-nilai konvensional yang sekarang berlaku dan dialami serta di praktekan oleh orang tua dan guru di sekolah. Tidak didapat kesimpulan yang positif bahwa peserta didik mendapatkan pengetahuan, nilai, sikap, dan keterampilan yang relevan agar bisa hidup dalam abad ke-21 (Sheldon F. Shaffer dalam Dadan Supardan, 2011). Dalam Pengambilan tema sejarah kontroversi sebaiknya berlandaskan prinsip rekonstruksi sosial, memandang peristiwa sejarah sebagai fenomena yang berlanjut untuk kepentingan masa depan.

Ambil contoh sederhana dalam kasus Gerakan 30 September 1965 (G30S), kita bisa saja berasumsi janganjangan mengajarkan peristiwa G30S menggunakan pendekatan yang selama ini kita berikan sudah tidak relevan lagi untuk masa depan (adanya konflik antara kelompok Islam, nasionalis dan komunis dalam periode 1959-1965, atau adanya hukum sebab akibat antara pembantaian terhadap kelompok Islam dan nasionalis oleh PKI, dengan periode yang terjadi setelahnya, misal kasus "jagal" kesaksian kelompok-kelompok ataupun individu yang terlibat dalam pembantaian anggota PKI). Jika pendekatan itu dijejalkan kepada peserta didik, salah satu efeknya bisa saja kita akan semakin sulit berdamai dengan masa lalu, stigma negatif mengenai masa lalu, prasangka antara pihak pelaku dan korban akan terus melekat, dalam pengertian yang ekstrem bangsa ini tanpa disadari turut memelihara konflik masa lalu. Jika kondisinya seperti itu, apa tidak sebaiknya kita mengajarkan sejarah G30S menitikberatkan pada pendekatan yang lebih humanis dalam arah menuju rekonsiliasi dan berdamai dengan masa lalu?

\section{NARASI FORMAL VS NARASI PINGGIRAN}

Menurut pandangan penulis, pembelajaran sejarah kontroversi dapat dilihat dari beberapa perspektif : pada satu titik sejarah kontroversi mampu merangsang peserta didik agar berpikir logis, kritis, dan kreatif, namun pada titik lain sejarah kontroversi dapat mengusik stabilitas kebangsaan, terutama kaitannya dengan kepentingan ideologis dan politis. Disinilah mulai muncul persinggungan antara sejarah sebagai alat pendidikan dan sejarah sebagai ilmu. Dalam pendidikan sejarah, materi sejarah diseleksi dan harus disesuaikan dengan tujuan pendidikan nasional yang menjadi kebijakan politik pemerintah (Agus Mulyana dalam Hamid Hasan, 2012: v). Sejarah diinterpretasikan dan dinarasikan secara formal atas dasar ideologi yang dijadikan pegangan pemerintah. Penafsiran sejarah pada ranah kurikulum merupakan bentuk dari official history yang diproduksi oleh pemerintah (Agus Mulyana dalam Hamid Hasan, 2012: vii). Misalkan bagaimana pemerintah begitu sensitif (bahkan anti) dengan ideology komunis, bukan tanpa alasan, melainkan adalah untuk menjaga keutuhan ideologi pancasila itu sendiri.

Sejarah dalam ranah keilmuan, sebagaimana yang dikemukakan oleh Sujatmoko (1995) bahwa sejarah harus netral dari ideology. Ilmu sejarah sebagai bagian dari disiplin ilmu harus memisahkan diri dari ikatan ideologi tertentu. Henk Schulte Nordholt (2008) mengistilahkan penulisan sejarah bebas dalam ranah keilmuan sebagai "narasi pinggiran". Perbedaan penafsiran antara narasi formal (official history) dan narasi pinggiran terkadang terjadi perbedaan 
dan dapat menimbulkan isu kontroversi didalam penulisan sejarah. Perbedaan penafsiran ini akan terus berlanjut selama motif kepentingan selalu ada dalam diri setiap individu ataupun kelompok, begitupun dengan ditemukannya data dan fakta baru yang akan mewarnai penulisan sejarah itu sendiri.

\section{PERLUKAH SEJARAH KONTROVERSI DIAJARKAN?}

Pembelajaran sejarah kontroversi adalah sebuah keniscayaan, perbedaan dalam sejarah akan selalu ada, selama penafsiran yang dibangun didasarkan atas pertimbangan yang berbeda, sejarah akan selalu berubah, selama ditemukan data dan fakta baru yang mendukung. Sejarah kontroversi akan lebih tepat jika diajarkan pada jenjang Sekolah Menengah Atas dan Perguruan Tinggi, hal ini karena kemampuan berpikir anak sudah mampu menyesuaikan dengan hal-hal (permasalahan) yang sifatnya kompleks dan membutuhkan nalar tinggi.

Sebagaimana di kemukakan Kuntowijoyo (2013: 3-4) di Sekolah Dasar sejarah dapat diajarkan dengan pendekatan estetis, menanamkan rasa cinta kepada perjuangan, tanah air, dan bangsa. Di Sekolah Menengah Pertama sejarah diberikan dengan pendekatan etis, ditanamkan pengertian bahwa peserta didik hidup berdampingan dengan lingkungan, masyarakat, dan kebudayaan yang bersifat majemuk. Sejarah diajarkan secara terpadu, karena sejarah merupakan bagian dari ilmu pengetahuan sosial berbarengan dengan geografi, sosiologi, dan ekonomi. Di Sekolah Menengah Atas sejarah dibahas secara kritis, peserta didik diajak berpikir mengenai sebab dan akibat dari sebuah peristiwa. Sedangkan di Perguruan Tinggi sejarah dikaji lebih akademis, dengan tujuan agar peserta didik (mahasiswa) mempunyai basis keilmuan yang kuat dan mampu membahas sebuah peristiwa secara komprehensif.

Penulis beranggapan materi kontroversi akan menarik jika diberikan tidak hanya dalam bentuk naratif (seperti pendekatan sejarah pada umumnya), melainkan diberikan dalam bentuk analisis dengan menggunakan pisau bedah yang disediakan dalam bentuk teori-teori ilmu sosial (misal bagaimana mengkaji kekuasaan orde baru dikaitkan dengan politik hegemoni ala Antonio Gramschi, atau melihat perlawanan Diponegoro tidak sekedar dari konflik lahan pemakaman saja, melainkan bagian dari gerakan milenarisme yang lahir dari dorongan mistis).

Sejarah kontroversi perlu diajarkan agar pembelajaran sejarah menjadi menarik dan tidak kaku. Bukankah kita semua sepakat bahwa pembelajaran sejarah tidak hanya menitikberatkan pada aspek kognitif semata, melainkan adanya keseimbangan pada aspek kognitif, afektif, dan keterampilan. Pemahaman akan fakta (nama, tempat, waktu) memang penting namun yang lebih utama adalah agar peserta didik mampu menjawab sebuah persoalan dalam kerangka berpikir sejarah (sebab-akibat, sinkronik-diakronik). Seperti dalam membahas materi G30S bukan pada siapa pelaku utama G30S, melainkan bagaimana dampak dari G30S terhadap struktur kehidupan masyarakat pada masa itu? dan apa korelasinya dengan kehidupan di masa sekarang? dimana kita masih ada kekhawatiran terhadap bahaya laten komunis, seolah untuk masalah komunis bangsa ini sulit berdamai dengan masa lalu?

Mengajarkan materi sejarah kontroversi bukanlah hal yang mudah, guru dituntut memiliki kedalaman bacaan 
yang memadai, selain itu guru harus mampu menstimulus anak agar mampu memberdayakan pemikiran logis dan kritis yang sebetulnya berpotensi dimiliki oleh semua anak. Hal lainnya guru tentu harus memiliki sisi kebijaksanaan dalam dirinya. Mengutip Francois Caron (Profesor Sejarah Universitas Sorbonne) “Tatkala sejarah menyadarkan kita tentang perbedaan-perbedaan, ia sebetulnya telah mengajarkan toleransi dan kebebasan" (Asvi Warman, 2007: 1).

\section{MENGAJARKAN SEJARAH KONTROVERSI: MEMBERIKAN PEMAHAMAN}

Untuk mengajarkan sejarah kontroversi diperlukan sosok guru yang mau berkomitmen untuk memberikan materi pembelajaran kontroversi di dalam kelas. Hal ini karena pembelajaran sejarah kontroversi membutuhkan persiapan dan keberanian guru dalam mengambil resiko (Harwood dan Hahn, 1990). Komitmen dan persiapan yang matang, diharapkan akan mampu mereduksi masalah-masalah teknis pembelajaran, seperti keterbatasan waktu, kelangkaan sumber dan media, materi ajar, serta pemilihan metode pembelajaran yang tepat. Jika secara pribadi guru sudah kuat, maka langkah selanjutnya adalah menguatkan peserta didik, dengan memberikan pemahaman tentang tujuan praksis (urgensi) pembelajaran sejarah kontroversi.

Di awal peserta didik harus ditekankan bahwa mempelajari sejarah kontroversi tidak hanya sekedar berbicara benar atau salah? Siapa pelaku utamanya? Kapan kejadiannya? Dimana tempatnya? (sekali lagi pemahaman akan dimensi kognitif-faktual sangat penting dalam mempelajari sejarah, akan tetapi diluar itu kita boleh mengabaikan penanaman nilai; berpikir logis, kritis, kreatif, kausalitas dan keterampilan sejarah; bercerita dan berargumen). Pembelajaran sejarah kontroversi akan bermakna jika peserta didik lebih dititikberatkan kepada proses (misal bagaimana mereka mencari data dan fakta dari sumber yang berbeda, bagaimana mereka menalar, berimajinasi, dan mengasosiasi dari kumpulan atau pendapatyangberbeda, bagaimana mereka mampu berargumen, berdialog satu sama lain untuk menguatkan pendapat ataupun versinya masing-masing). Jika proses ini berjalan peran guru sebagai fasilitator sangat diperlukan, terutama dalam mengajarkan kebijaksanaan, bahwa dalam dunia akademik, perbedaan (selama bisa dipertanggungjawabkan) adalah merupakan hal yang lumrah, nilai pendidikan karakter dengan sendirinya terjalin dalam proses ini.

\section{MENGAJARKAN SEJARAH KONTROVERSI: MODEL PEMBELAJARAN SOSIAL}

Model pembelajaran sosial dibangun untuk mendapatkan keuntungan, dari adanya fenomena bahwa dalam belajar tidak hanya bertumpu pada aspek kognitif semata, aspek afektif dan ketrampilan juga dibutuhkan dalam membuat komunitas pembelajaran (Joyce,Weil dan Calhoun, 2011: 34-35). Model pembelajaran sosial menekankan pada aktivitas pembelajaran gotong-royong dan upaya peserta didik dalam membangun pengetahuan sendiri. Setidaknya ada dua model pembelajaran sosial yang cocok digunakan dalam mengajarkan sejarah kontroversi, yaitu:

a. Investigasi Kelompok

Model ini dapat melatih guru dan peserta didik untuk mengembangkan suasana demokrasi (mengemukakan pendapat dan argumentasi) dalam pembelajaran di kelas. Peserta didik berperan aktif dalam 
membahas dan menyelesaikan sebuah tema kontroversi. Adapun langkahlangkah dan aplikasi model pembelajaran sosial menurut Joyce, Weil dan Calhoun (2011: 299-324) adalah sebagai berikut:

1. Menyajikan situasi yang rumit

Aplikasi dalam pembelajaran sejarah, guru dapat mengemukakan tema-tema kontroversi. Misal guru mengemukakan fakta yang bertentangan dengan pendapat umum bahwa pada kasus Serangan Umum Satu Maret 1949 yang berperan sebagai "aktor intelektual" sebenarnya adalah Sri Sultan Hamengkubuwono IX, bukan Suharto.

2. Menjelaskan dan menguraikan reaksi terhadap situasi

Peserta didik diminta untuk mengidentifikasi setiap reaksi yang diperlihatkan peserta didik lain dan mencoba menjelaskan apa yang harus dilakukan untuk kegiatan selanjutnya dalam rangka mendapatkan penjelasan yang lebih lengkap.

3. Merumuskan definisi masalah, peran, tugas, dan mengaturnya dalam pembelajaran.

Berdasarkan keterangan di atas, guru bersama peserta didik merumuskan tugas yang harus dikerjakan oleh peserta didik, misal guru membagi peserta didik ke dalam beberapa kelompok kemudian memberikan tugas seperti mengumpulkan sumbersumber mengenai Serangan Umum Satu Maret 1949.

4. Studi mandiri dan berkelompok

Setiap kelompok melakukan kerja mandiri mengumpulkan sumbersumber untuk menjelaskan fakta yang memperkuat peran Sri Sultan Hamengkubuwono IX dalam Serangan Umum Satu Maret 1949.

5. Menganalisis perkembangan dan proses

Peserta didik saling sharing dan konfirmasi mengenai jawaban atau fakta yang mereka peroleh.

6. Mendaur ulang aktivitas

Setelah jawaban diperoleh setiap kelompok merumuskan langkah yang lebih efektif atau mengatur kembali cara terbaik dalam menyelesaikan tugas.

\section{b. Model Jurispudensi}

Model ini dimaksudkan agar peserta didik belajar merespon secara kritis tema berupa peristiwa maupun kebijakan-kebijakan yang bersifat kontroversi dalam sejarah. Langkah-langkah dan aplikasi model jurispudensi adalah sebagai berikut:

1) Mengarahkan peserta didik pada tema

Aplikasi dalam pembelajaran sejarah, di awal guru memperkenalkan tema atau mereview fakta.

2) Mengidentifikasi tema

Guru dan peserta didik mengidentifikasi tema kemudian mengidentifikasi konflik dan nilai. Misal pada tema konflik antara pusat dan daerah 1945-1950 yang melahirkan pergolakan di daerah-daerah sebagai bentuk ketidakpuasaan atas kebijakan pemerintah pusat. Dari tema tersebut dapat dirumuskan beberapa fakta dan nilai antara lain: primordialisme, orientasi idealisme dan materialisme, ketidakadilan, kesenjangan ekonomi, patriotisme. 
3) Menentukan sikap dan memposisikan diri

Peserta didik diminta memilih berada pada posisi pro atau kontra, kemudian menganalisis dan mempertimbangkan dampak dari masing-masing pilihan.

4) Membentuk argumentasi dan mengeksplorasi sikap

Peserta didik diminta menyusun argumentasi dan menjelaskan mengapa pilihan yang dipilih menjadi prioritas untuk dilakukan.

5) Memperhalus dan mengkualifikasi posisi

Peserta didik diminta menyatakan alasan mengambil posisi tersebut dan membuat perbandingan pada situasi yang hampir mirip.

6) Menguji asumsi-asumsi faktual

Peserta didik mengidentifikasi argumentasi yang dibuat dan menganalisa apakah argumentasi itu relevan, selanjutnya mempertimbangkan bagaimana jika asumsi-asumsi yang dibangun benarbenar terjadi.

\section{Pendekatan dan Strategi dalam Pembelajaran Sejarah Kontroversi}

Beberapa pendekatan dan strategi yang ditawarkan dalam mengajarkan sejarah kontroversi antara lain (Tsabit Azinar Ahmad, 2012):

1. Exclusive Neutrality: Guru tidak membahas dan memperkenalkan materi sejarah kontroversi.

2. Exclusive Partiality: Guru memperkenalkan dan membela salah satu versi saja.

3. Neutral Impartiality: Guru memperkenalkan materi kontroversi, tetapi menghindar untuk menjelaskan secara spesifik.

4. Commited Impartiality. Guru memperkenalkan, membahas, dan mendiskusikan materi sejarah kontroversi kepada peserta didik.

Guru yang baik dan berkompeten tentunya harus mampu memposisikan diri dan memilih pendekatan commited impartiality di dalam mengajarkan materi sejarah kontroversi. Jika guru sudah berkomitmen untuk mengajarkan materi sejarah kontroversi, maka ada beberapa strategi alternative yang bisa dijalankan yaitu:

1. Commited: Guru menyampaikan hanya satu versi materi sejarah kontroversi yang di yakini dan di kuasai untuk di diskusikan.

2. Objective: Guru menyampaikan seluruh versi berdasarkan pendapatpendapat dari sejarawan atau sebagaimana tertulis dalam literaturliteratur sejarah tanpa mengemukakan pendapat pribadinya.

3. Devils Advocate: Guru mengambil peran atau posisi yang berlawanan (kontra) dengan pendapat peserta didik, hal ini untuk memancing dialog atau diskusi.

4. Advocate: Guru menyampaikan seluruh versi dan memberikan kesimpulan dari (salah satu) versi yang di dukung, dan mempersilahkan peserta didik memberikan penilaian.

5. Impartial Chairperson: Guru menstimulus peserta didik, agar mereka mampu memunculkan versi- 
versi yang berbeda dalam proses dialog atau diskusi.

6. Declarated Interest: Guru menjelaskan salah satu versi untuk dikritisi kemudian diinvestigasi oleh peserta didik.

Guru bisa memilih diantara strategi yang ditawarkan, semua tergantung tujuan yang ingin dicapai dan melihat kondisi peserta didik disekolah masingmasing. Yang jelas sebagai fasilitator guru harus mampu menampilkan cara pandang yang apa adanya (objective), logis (masuk akal), neutral (tidak tendensius), balance (seimbang) dan berpijak pada data dan fakta yang jelas (reason).

\section{KESIMPULAN}

Perkembangan zaman pada hakikatnya berjalan lurus dengan perkembangan ilmu pengetahuan itu sendiri. Pasca rezim orde baru tumbang, struktur sosial-politis memunculkan narasi dan tafsir-tafsir baru yang secara otomatis melahirkan adanya "gugatan" di dalam melihat ataupun mengkaji peristiwa sejarah yang selama ini diyakini. Tafsir ini biasanya lahir dari para sejarawan yang dengan etika keilmuannya berusaha menyampaikan sesuatu secara apa adanya sekaligus membuka tabir terhadap sesuatu yang selama ini dianggap "ditutup tutupi".

Sejarah sesungguhnya memiliki dua wajah, satu sisi sejarah sebagai sebuah disiplin ilmu dan disisi lain sejarah sebagai sarana pendidikan. Kedua sisi ini seringkali berbenturan satu sama lain. Disaat sebagian suara menuntut sejarah harus disampaikan apa adanya (mengacu kepada sumber-sumber yang mendukung), suara lainnya bertahan dengan asumsi sejarah harus mengikuti kepentingan politis penguasa (mengacu kepada landasan ideologis yang dianut oleh Negara).

Guru sejarah tidak bisa menghindari realitas ini, justru guru sejarah harus mampu menjawab realitas ini dengan memberikan pemahaman kepada peserta didik sekaligus melaksanakan pembelajaran sejarah kontroversi yang mampu beradaptasi dengan perkembangan zaman. Guru sejarah yang kontekstual harus mampu memberikan variasi dan mengkolaborasikan metodemetode pembelajaran berdasarkan pendekatan konstruktivis, berpikir terbuka, kaya akan referensi, bijaksana, serta tidak memaksakan kehendak ataupun tafsirnya dalam melihat sebuah teks dan peristiwa sejarah.

Pembelajaran sejarah kontroversi lebih menekankan pada proses yang bertujuan agar peserta didik mampu memberdayakan nalarnya secara logis, kritis, dan kreatif. Sebagaimana yang sudah dikemukakan di pembahasan, adanyajarak antara masa lampau dan masa sekarang hanya dapat dilihat dengan cara membangun "jembatan penghubung", yang disusun dari kontruksi berpikir peserta didik. Peserta didik dituntut kreatif (berimajinasi, membayangkan) situasi masa lampau yang berkaitan erat dengan masa sekarang, termasuk mencoba melihat kemungkinan-kemungkinan yang akan terjadi di masa yang akan datang. Banyaknya sumber-sumber dan tafsir yang "menyelimuti" peristiwa sejarah pastinya akan membentuk sisi kritis peserta didik, untuk memilah mana sumber dan tafsir yang bisa diterima secara logis. Jika merujuk pada pendekatan konstruktivis, guru berperan penting dalam menumbuhkembangkan potensi yang ada di dalam diri peserta didik. 
Model pembelajaran sosial yang bertumpu pada aspek gotong-royong dan kemampuan peserta didik dalam membangun pengetahuan sangat cocok di terapkan dalam pembelajaran kontroversi. Melalui investigasi kelompok dan model jurispudensi peserta didik di berikan ruang untuk memilih tema, mencari sumber-sumber, dan mengemukakan hasil kerjanya secara bergantian. Pada aplikasinya peserta didik dituntut untuk kritis dalam menanggapi setiap tema dan mengemukakan argumentasinya secara logis berdasarkan sumber-sumber yang mendukung. Selain itu peserta didik juga akan menjadi kreatif karena diajak untuk berpikir kearah kemungkinan (memposisikan diri di posisi pelaku, dan mempertimbangkan seandainya asumsi-asumsi yang kita bangun menjadi kenyataan).

Perubahan dalam sejarah adalah sebuah keniscayaan, sebab sejarah bukanlah benda sakral yang pantang untuk disentuh apalagi digubah. Sejarah identik dengan keterbukaan, keterbukaan yang bisa dicapai selama ada sumber-sumber (data dan fakta baru yang ditemukan). Berdasarkan prinsip keilmuan biarkanlah sejarawan bekerja, memecahkan peristiwa sejarah dan memberikan narasi yang jujur, apa adanya, dan bisa dipertanggungjawabkan secara akademis. Tugas guru sebagai pendidik yang memiliki hak otonomi dalam mengajar (pelajaran sejarah) di kelas, tentu memiliki kebebasan di dalam proses "transfer of knowledge" dan "transfer of value".

Tanpa mengabaikan narasi dan tafsir dari sejarawan, dalam ranah pendidikan guru berhak memilah mana nilai-nilai yang patut diajarkan dan nilai-nilai yang seharusnya dihindarkan, termasuk memilih pendekatan dan strategi yang dipakai dalam pembelajaran sejarah kontroversi, semua tergantung dari sudut pandang guru itu sendiri.

\section{Daftar Pustaka}

Adam, Asvi Warman, Seabad Kontoversi Sejarah, Yogyakarta: Ombak. 2007

Ahmad, Tsabit Azinar (2012). Mengajarkan Isu Kontroversial: versi ringkas dari makalah yang dipresentasikan dalam Seminar Nasional Reformulasi Pendidikan Sejarah di UNY. Diunduh tanggal 3 Mei 2015 dari http://sejarahkritis.wordpress. com/2012/10/16/mengajarkan-isukontroversial

Creswell, W. John, Research Design Pendekatan Kualitatif, Kuantitatif, dan Mixed. Yogyakarta: Pustaka Pelajar. 2010

Emzir, Metodologi Penelitian Pendidikan Kuantitatif dan Kualitatif. Jakarta: Rajawali Pers. 2011

Frederick H. William dan Soeri Soeroto (Penyunting), Pemahaman Sejarah Indonesia Sebelum dan Sesudah Revolusi. Jakarta: LP3ES.2005

Hasan, Hamid, (2012). Pendidikan Sejarah Indonesia, Isu dalam Ide dan Pembelajaran. Bandung: Rizqi Press.

Hastuti, Elly. Peningkatan Kesadaran Sejarah Siswa Melalui Pemanfaatan Sumber Belajar Isu Kontroversi. Jurnal Teknologi Pendidikan, Vol. 10, No. 2 Agustus 2008.

Issom, Sri Sjamsiar dan M. Fakhruddin, . Makalah Kontroversi Sejarah Orde Baru: Permasalahan Sekitar Pembelajaran Sejarah di Sekolah. Kongres Ilmu Pengetahuan Nasional VII. Serpong.1999

Pengajaran. Yogyakarta: Pustaka Pelajar.2011 
Kasemin, Kasiyanto,. Mendamaikan sejarah: Analisis Wacana Pencabutan TAP MPRS/XXV/1966. Yogyakarta: LKIS.2003

Kuntowijoyo, Pengantar Ilmu Sejarah. Yogyakarta: Tiara Wacana.2013

Nazir, M, Metode Penelitian. Jakarta: Ghalia Indonesia.2003

Subakti, Y.R. Paradigma Pembelajaran Sejarah Berbasis Konstruktivisme. Jurnal SPPS, Vol. 24, No. 1 April 2010.

Supardan, Dadang,Pengembangan Kreatifitas Guru Dalam Pembelajaran Sejarah; Prosiding Seminar Nasional Pendidikan Sejarah. Bandung: Laboratorium Jurusan Pendidikan sejarah FPIPS UPI.2011

Tim Penyusun Pedoman Bahan Ajar Sejarah Bagi Guru Sekolah Menengah (SMU/ MA,SMK),Kurikulum 1994 Suplemen GBPP Mata Pelajaran Sejarah. Jakarta: Departemen Pendidikan Nasional, Direktorat Jenderal Pendidikan Dasar dan Menengah.2001 


\title{
Kurikulum Pendidikan di SD dan SMA Pada Masa Orde Baru
}

\author{
Oleh : Andi Dewi Riang Tati
}

Fakultas Ilmu Pendidikan Universitas Negeri Makassar

\begin{abstract}
The new order lasts from 1968 to 1998 , and can be regarded as the era of national development. In the field of development of education, especially primary education, there is a significant leap in the presence of Presidential Decree (Presidential Instruction) Basic Education. The implementation of education in the new order turned out to be many obstacles , because the new order brings educational ideology of " uniformity " that compress the progress in the field of education. In the new order of educational equality in education can not be created because the elements dominating and submissive still very strong in the education pattern of the new order.
\end{abstract}

Keywords: Education New Orde

\begin{abstract}
Abstrak
Orde baru berlangsung dari tahun 1968 hingga 1998, dan dapat dikatakan sebagai era pembangunan nasional. Dalam bidang pembangunan pendidikan, khususnya pendidikan dasar, terjadi suatu loncatan yang sangat signifikan dengan adanya Instruksi Presiden (INPRES) Pendidikan Dasar. Pelaksanaan pendidikan pada masa orde baru ternyata banyak menemukan kendala, karena pendidikan orde baru mengusung ideologi "keseragaman" sehingga memampatkan kemajuan dalam bidang pendidikan. Pada pendidikan orde baru kesetaran dalam pendidikan tidak dapat diciptakan karena unsur dominatif dan submisif masih sangat kental dalam pola pendidikan orde baru.
\end{abstract}

Kata Kunci; Pendidikan Orde Baru

\section{PENDAHULUAN}

Orde baru berlangsung dari tahun 1968 hingga 1998, dan dapat dikatakan sebagai era pembangunan nasional. Dalam bidang pembangunan pendidikan, khususnya pendidikan dasar, terjadi suatu loncatan yang sangat signifikan dengan adanya Instruksi Presiden (INPRES) Pendidikan Dasar. Namun, yang disayangkan adalah pengaplikasian INPRES ini hanya berlangsung dari segi kuantitas tanpa diimbangi dengan perkembangan kualitas. Yang terpenting pada masa ini adalah menciptakan lulusan terdidik sebanyak-banyaknya tanpa memperhatikan kualitas pengajaran dan hasil didikan.
Pada pendidikan Orde Baru kesetaran dalam pendidikan tidak dapat diciptakan karena unsur dominatif dan submisif masih sangat kental dalam pola pendidikan orde baru. Pada masa ini, peserta didik diberikan beban materi pelajaran yang banyak dan berat tanpa memperhatikan keterbatasan alokasi kepentingan dengan faktor-faktor kurikulum yang lain untuk menjadi peka terhadap lingkungan. Beberapa hal negatif lain yang tercipta pada masa ini adalah:

1. Produk-produk pendidikan diarahkan untuk menjadi pekerja. Sehingga, 
berimplikasi pada hilangnya eksistensi manusia yang hidup dengan akal pikirannya (tidak memanusiakan manusia);

2. Lahirnya kaum terdidik yang tumpul akan kepekaan sosial, dan banyaknya anak muda yang berpikiran positivistik;

3. Hilangnya kebebasan berpendapat.

Pada dua periode pertama kekuasaan Soeharto (1968-1973 dan 1973-1978), pendidikan sebagai wahana pembelajaran dan penggodokan calon pemimpin masih diteruskan dengan baik. Hanya saja dinamika pergerakan mahasiswa dan pelajar untuk mengkritisi pembangunan Soeharto, berujung pada apa yang disebut Malapetaka 15 Januari 1974 dan terbitnya Buku Putih Perjuangan Mahasiswa 1978 untuk menolak Soeharto kembali menjadi Presiden untuk ketiga kalinya.

\section{METODOLOGI PENELITIAN}

Sejalan dengan pemerintahan Soeharto yang otoriter, tampaknya isu tentang pendidikan dikesampingkan, terutama mungkin terkait dengan kekhawatiran akan timbulnya gejolak apabila pendidikan politik benar-benar dilakukan sepenuhnya. Sejak saat itu, pendidikan digunakan sebagai kendaraan politik bagi pemerintahan Soeharto untuk melakukan indoktrinasi terhadap rakyat.

Sejak saat itu, fokus pembangunan lebih diarahkan kepada pembangunan ekonomi daripada pembangunan manusia. Departemen Pendidikan pun tumbuh menjadi kementerian yang termarjinalisasi dibandingkan dengan departemen lain. Rosser (2002) mencatat, pada tahun 1980-an Menteri Sekretaris Negara (saat itu dipimpin Sudharmono dan Ginandjar Kartasasmita) dan Menteri
Riset dan Teknologi (saat itu dipimpin BJ.Habibie) merupakan kementerian yang memegang peran utama dalam perencanaan pembangunan.

Dalam hal intervensi terhadap pendidikan, kebijakan Orde Baru mirip kebijakan kolonial. Praktik pendidikan disterilkan dari politik praktis. Kurikulum dan buku pelajaran tertentu disusun menurut versi politik pemerintah. Seperti kolonial, gaya pemerintahan Orde Baru menimbulkan resistensi kelompokkelompok kritis terhadap dominasi kekuasaan.

Di era Orde Baru kebebasan sedikit demi sedikit direnggut sampai tidak tersisa samasekali. Membaca buku tertentu bahkan dianggap sebagai tindakan kriminal. Kebebasan berorganisasi dikooptasi dengan adanya organisasiorganisasi yang sudah korporatis pada kekuasaan, sehingga memarjinalisasi politik mahasiswa. Kebebasan akademis dikekang dengan perlunya izin kegiatan dari pihak yang berwenang. sekolah telah dipisahkan dari soal-soal nyata seharihari. (Harefa, 2000) .

Selama mengikuti proses pembelajaran di sekolah, peserta didik (nyaris) tidak pernah bersentuhan dengan pendidikan nilai yang berorientasi pada pembentukan watak dan kepribadian. Mereka diperlakukan bagaikan "tong sampah" ilmu pengetahuan yang harus menerima apa saja yang dijejalkan dan disuapkan oleh para guru. Hal itu diperparah dengan munculnya kebijakan pemerintah masa lalu yang cenderung sentralistis dan otoriter, sehingga memberangus dan mengebiri fungsi sekolah sebagai pusat pendidikan nilai religi, sosial, budaya, ilmu pengetahuan, moral, kemanusiaan, dan semacamnya. 
Yang lebih memprihatinkan, pendidikan dinilai hanya dijadikan sebagai alat untuk melanggengkan kekuasaan melalui berbagai polarisasi, indoktrinasi, sentralisasi, dan regulasi yang tidak memihak rakyat. Keluaran pendidikan tidak digembleng untuk mengabdi kepada rakyat, tetapi telah dipola dan dibentuk untuk mengabdi kepada kepentingan kekuasaan.

Sebagaimana sistem politik yang ada pada era ini, maka manajemen pendidikan dilaksanakan secara sentralistis. Semua kebijakan sampai detail ditentukan oleh pusat. Sekolah sebagai lembaga yang langsung melaksanakan proses pembelajaran tidak memiliki kewenangan yang memadai. Kebijakan ini memiliki implikasi perencanaan dan upaya peningkatan mutu bersifat top-down. Akibatnya, peningkatan mutu tidak ada disekolah-sekolah, dan hanya ada di pusat.

Sejalan dengan pemerintahan Soeharto yang otoriter, tampaknya isu tentang pendidikan mulai dikesampingkan, terutama terkait dengan kekhawatiran akan timbulnya gejolak apabila pendidikan politik benarbenar dilakukan sepenuhnya. Sejak saat itu kita lebih melihat pendidikan digunakan sebagai kendaraan politik bagi pemerintahan Soeharto untuk melakukan indoktrinasi terhadap rakyat. Rezim Orde Baru amat yakin akan terjadi mukjizat yang meneteskan hasil pembangunan kepada rakyat miskin (trickle down effects).

Kebijakan pendidikan pada masa Orde Baru diarahkan pada penyeragaman. Tilaar (2002:3) menjelaskan pendidikan di masa ini diarahkan kepada uniformalitas atau keseragaman di dalam berpikir dan bertindak. Pakaian seragam, wadah-wadah tunggal dari organisasi sosial masyarakat, semuanya diarahkan kepada terbentuknya masyarakat yang homogen. Pada masa ini tidak ada tempat bagi perbedaan pendapat, sehingga melahirkan disiplin semu dan melahirkan masyarakat peniru. Pada masa ini pertumbuhan ekonomi yang dijadikan panglima. Pembangunan tidak berakar pada ekonomi rakyat dan sumber daya domestik, melainkan bergantung pada utang luar negeri sehingga melahirkan sistem yang tidak peka terhadap daya saing dan tidak produktif. Berbagai layanan publik tidak mempunyai akuntabilitas sosial oleh karena masyarakat tidak diikutsertakan di dalam manajemennya. Bentuk pembangunan pada saat itu mengingkari kebhinekaan serta semakin mempertajam bentuk primordialisme. Penerapan pendidikan tidak diarahkan lagi pada peningkatan kualitas melainkan pada target kuantitas.

Para penguasa terlalu banyak
mencampuri dan "mengarahkan" sistem pendidikan, sehingga apa yang disebut filsafat pendidikan nyaris tidak terefleksikan dalam setiap tindakan pendidikan maupun pembelajaran. Sistem pendidikan, ataupun mungkin lebih sempit dari itu: sistem persekolahan terlalu banyak digunakan sebagai vehicle untuk transmisi sosial membangun kehidupan bersama dan menomorduakan kebhinekaan demi keekaan. Konvergensi dan kesamaan tujuan pembangunan. Dengan demikian membangun manusia Indonesia seutuhnya sebenarnya telah direduksikan dalam tindak pendidikan. (Semiawan, C, 2000: 21).

Dalam era orde baru ini dikenal sebagai era pembangunan nasional. Dalam bidang pembangunan pendidikan, khususnya pendidikan dasar terjadi suatu loncatan yang sangat signifikan dengan adanya INPRES Pendidikan Dasar. Tetapi sayang sekali INPRES Pendidikan Dasar belum ditindak lanjuti dengan 
peningkatan kualitas tetapi baru kuantitas. Dalam era pembangunan nasional selama lima REPELITA yang ditekankan ialah pembangunan ekonomi sebagai salah satu dari TRILOGI pembangunan. Maka kemerosotan pendidikan nasional telah berlangsung. Selain itu sistem ujian Negara (EBTANAS) telah berubah menjadi bumerangyaitu penentuan kelulusan siswa menurut rumus-rumus tertentu. Akhirnya di tiap-tiap lembaga pendidikan sekolah berusaha untuk meluluskan siswanya $100 \%$. Hal ini berakibat pada suatu pembohongan publik dan dirinya sendiri dalam masyarakat. Oleh sebab itu era Orde Baru pendidikan telah dijadikan sebagai indikator palsu mengenai keberhasilan pemerintah dalam pembangunan. Dari hasil manipulasi ujian nasional sekolah dasar kemudian meningkat ke sekolah menengah dan kemudian meningkat ke sekolah menengah tingkat atas dan selanjutnya berpengaruh pada mutu pendidikan tinggi

Ada beberapa kebijakan pokok dalam pendidikan pada masa Orde Baru, yaitu:

\section{a. Relevansi Pendidikan}

Yaitu penyesuaian isi pendidikan dengan kebutuhan pembangunan terhadap sumber daya manusia yang diperlukan. Kebijakan ini secara eksplisit muncul pada pelita I, II, III, IV dan V. Setelah perluasan kesempatan belajar, sasaran perbaikan bidang pendidikan selanjutnya adalah pemberantasan buta aksara. Kenyataan bahwa masih banyak penduduk yang buta huruf ditanggapi pemerintahan Soeharto dengan pencanangan penuntasan buta huruf pada 16 Agustus 1978.

Keberhasilan program kejar salah satunya terlihat dari angka statistik penduduk buta huruf yang menurun. Pada sensus tahun 1971, dari total jumlah penduduk 80 juta jiwa,Indonesia masih memiliki 39,1 persen penduduk usia 10 tahun ke atas yang berstatus buta huruf. Sepuluh tahun kemudian, menurut sensus tahun 1980, persentase itu menurun menjadi hanya 28,8 persen. Hingga sensus berikutnya tahun 1990, angkanya terus menyusut menjadi 15,9 persen.

Corak politik pemerintah yang demikian itu selanjutnya menimbulkan paling kurang enam masalah pendidikan. Pertama, masih banyak rakyat Indonesia yang belum memperoleh pendidikan. Kedua, mutu lulusan pendidikan di Indonesia tergolong rendah dibandingkan dengan mutu lulusan pendidikan di negara lain. Ketiga, pendidikan di Indonesia belum menjadi pranata sosial yang kuat dalam memberdayakan sumber daya manusia Indonesia. Keempat, pendidikan di Indonesia belum berhasil melahirkan lulusan yang mengamalkan keimanan, ketakwaan, aklak mulia dan budi pekerti luhur. Kelima, pendidikan belum mampu mendorong lahirnya masyarakat belajar (learning society) dalam rangka pelaksanaan konsep belajar seumur hidup. Keenam, dunia pendidikan kurang sejalan dengan tuntutan dunia kerja dan kebutuhan lokal.

\section{b. Pemerataan Pendidikan}

Sejak pelita I disadari pentingnya memberikan kesempatan yang sama dan lebih luas tentang pendidikan untuk semua warga negara. Kebijakan pemerataan dan perluasan pendidikan dilaksanakan melalui wajib belajar Sekolah Dasar. Sejak awal kekuasaannya sebagai Presiden RI, Soeharto berupaya menggarap pendidikan sebagai hal yang harus dibenahi secara serius. Tiga hal yang cukup populer di masyarakat adalah, pertama; program 
wajib belajar, kedua; pembangunan SD Inpres, ketiga; pembentukan kelompok belajar atau kejar. Dengan mencanangkan "wajib belajar 9 tahun", termasuk juga yang tak kalah populer adalah dibukanya program SD Inpres untuk daerah-daerah terpencil dan terisolir diberbagai belahan daerah di Indonesia. Program wajib belajar dicanangkan pada 2 Mei 1984, diakhir Pelita (Pembangunan Lima Tahun) III. Dalam sambutannya saat itu, Soeharto menyatakan, kebijakan ini bertujuan untuk memberikan kesempatan yang sama dan adil kepada seluruh anak usia 7-12 tahun di belahan bumi Indonesia mana pun dalam menikmati pendidikan dasar. Seremonial pencanangan dilakukan secara besar-besaran di Stadion Utama Senayan, Jakarta. Program ini memang telah direncanakan saat Pelita II. Tidak murni seperti kebijakan wajib belajar di negara lain yang memiliki unsur paksaan dan ada sanksi bagi yang mengabaikan. Pemerintah hanya mengimbau orangtua agar memasukkan anaknya yang sudah cukup umur ke sekolah. Negara bertanggung jawab terhadap penyediaan sarana dan prasarana pendidikan yang dibutuhkan, seperti gedung sekolah, peralatan sekolah, disamping tenaga guru dan kepala sekolah. Karena tidak ada sanksi, dalam prosesnya hingga kini, masih ditemukan anak-anak pada kelompok usia pendidikan dasar yang tidak bersekolah. Upaya pelaksanaan wajib belajar 9 tahun pada kelompok usia 7-15 tahun dimulai saat diresmikannya Pencanangan Wajib Belajar Pendidikan Dasar 9 Tahun pada 2 Mei 1994. Kebijakan ini diperkuat dengan dikeluarkannya Instruksi Presiden (Inpres) Nomor 1 Tahun 1994. Program wajib belajar yang dimulai Soeharto di akhir Pelita III diakui telah meningkatkan taraf pendidikan masyarakat Indonesia saat itu. Fokus utama ketika itu adalah peningkatan angka-angka indikator kualitas pendidikan dasar. Sebelum wajib belajar dicanangkan, upaya peningkatan kualitas pendidikan dasar didahului dengan dikeluarkannya Inpres No 10/1973 tentang Program Bantuan Pembangunan Gedung SD.

Pelaksanaan program wajib belajar yang diikuti dengan penambahan fasilitas pendidikan diwujudkan dengan peningkatan jumlah sekolah dan guru SD di seluruh Indonesia. Sebelum program Rencana Pembangunan Lima Tahun (REPELITA) dilaksanakan, jumlah gedung SD yang tercatat pada tahun 1968 sebanyak 60.023 unit dan gedung SMP 5.897unit. Pada awal Pelita VI, jumlah itu telah meningkat menjadi sekitar 150.000 gedung SD dan 20.000 gedung SMP. Pelaksanaan tahap pertama program SD Inpres adalah pembangunan 6.000 gedung SD yang masing-masing memiliki tiga ruang kelas. Ketika itu Indonesia baru saja mendapat limpahan dana hasil penjualan minyak bumi yang harganya naik sekitar 300 persen dari sebelumnya. Uang itu kemudian digunakan untuk mempercepat pemenuhan kebutuhan dasar masyarakat, salah satunya pendidikan. Pada tahuntahun awal pelaksanaan program SD Inpres, hampir setiap tahun, ribuan hingga puluhan ribu gedung sekolah dibangun. Pembangunan paling besar terjadi pada periode 1982/1983 ketika 22.600 gedung SD baru dibuat. Hingga periode 1993/1994 tercatat hampir 150.000 unit SD inpres telah dibangun. Seiring dengan pembangunan gedung SD inpres tersebut, ditempatkan pula satu juta lebih guru inpres di sekolah-sekolah itu. Total dana yang dikeluarkan untuk program ini hingga akhir Pembangunan Jangka Panjang (PJP) I mencapai hampir Rp 6,5 triliun.

Keberhasilan program wajib belajar 6 tahun ditandai dengan kenaikan angka 
partisipasi Sekolah Dasar (SD) sebesar 1,4 persen. Angka partisipasi SD menjadi 89,91 persen diakhir Pelita IV. Kenaikan angka partisipasi itu menambah kuat niat pemerintah untuk memperluas kelompok usia anak yang ikut program wajib belajar selanjutnya, menjadi 7-15 tahun, atau tamat sekolah menengah pertama (SMP). Jumlah guru SD yang sebelumnya pada kisaran angka ratusan ribu, pada awal tahun 1994 menjadi lebih dari satu juta guru. Lonjakan jumlah guru dari puluhan ribu menjadi ratusan ribu juga terjadi pada guru SMP.

\section{METODE PENELITIAN}

Penelitian ini menggunakan pendekatan penelitian sejarah. Menurut Hariyono (1995:109) meliputi langkahlangkah yaitu heuristic, kritik, interpretasi, dan historiografi. Langkah pertama dilakukan pengumpulan data (heuristic) terhadap buku-buku atau dokumendokumen yang akan dijadikan sumber data sebagai landasan untuk melakukan analisis. Jurnal-jurnal, buku-buku dan dokumen-dokumen yang dikumpulkan yaitu berkaitan dengan pendidikan dan pembentukan karakter di sekolah. Langkah kedua yaitu kritik sumber. Kritik sumber dilakukan sebagai filter secara kritis dalam melakukan penilaian sumber menyangkut otentitas dan kepercayaan sumber. Kritik dilakukan melalui 2 (dua) tahap baik kritik intern (materi sumber) maupun kritik ekstern (subtansi atau isi). Langkah ketiga yaitu interpretasi (penafsiran) yaitu peneliti melakukan penafsiran terhadap sumber-sumber data yang telah dikritik baik intern maupun ekstern, dan langkah keempat yaitu historiografi (penulisan) yaitu tahapan sintesis dari hasil penyeledikan sehingga pada akhirnya melahirkan tulisan yang utuh melalui proses rekonstruksi. Menurut Lois.

\section{HASIL DAN PEMBAHASAN Kurikulum 1984 di SD}

Prinsip dan pendekatan pengembangan Kurikulum 1984 berbeda dengan yang digunakan pada Kurikulum 1975. Prinsipprinsip pengembangan Kurikulum 1984 dikemukakan berikut ini:

1. Pendekatan belajar lebih menekankan bagaimana anak belajar daripada apa yang dipelajari, tanpa mengabaikan ketuntasan belajar yang memperhatikan kecepatan belajar murid.

2. Kegiatan penilaian terutama diarahkan kepada upaya untuk menentukan seberapa jauh tujuantujuan, baik yang bersifat proses maupun hasil belajar yang diinginkan, telah terwujud.

3. Pengembangan kurikulum sekolah dasar berpedoman pada:

a. Pancasila dan Undang-Undang Dasar 1945: Kurikulum dikembangkan dengan berdasarkan Pancasila dan Undang-Undang Dasar 1945, serta berpedoman pada GBHN yang berlaku dalam rangka mewujudkan cita-cita pembangunannasional pada umumnya dan tujuan pendidikan nasional pada khususnya.

b. Relevansi: Kurikulum dikembangkan dengan mempertimbangkan baik tuntutan kebutuhan murid pada umumnya maupun tuntutan kebutuhan murid secara perorangan sesuai dengan minat, bakat dan kemampuannya, serta kebutuhan lingkungan pada khususnya. 
c. Pendekatan

Pengembangan

pengembangan:

dilakukan secara terus-menerus, sesuai dengan perkembangan ilmu pengetahuan dan teknologi, kebijaksanaan pemerintah, dan hasil-hasil penilaian terhadap pelaksanaan dan hasil-hasil yang telah dicapai untuk mengadakan perbaikan dan pemantapan pengembangan lebih lanjut.

d. Pendidikan seumur hidup: Kurikulum dikembangkan untuk membuka kemungkinan pelaksanaan pendidikan seumur hidup.

e. Keluwesan: Kurikulum dikembangkan dengan mempertimbangkan keluwesan program dan pelaksanaannya. (Sumber: Kurikulum 1984 SD (Sekolah Dasar): Landasan, Program, dan Pengembangan, Jakarta: Pusatbangkurrandik, Depdikbud, 1984).

Pengembangan Kurikulum 1984 menggunakan pendekatan keterampilan proses (process skill approach), yang diperkenalkan Wynne Harlen, seorang ahli sains untuk sekolah dasar dari Inggris yang menjadi konsultan sains bagi Pusat Kurikulum dalam rangka kerja sama antara Pemerintah Inggris dan Departemen Pendidikan dan Kebudayaan yang diwakili Pusat Kurikulum BP3K. Konsultan yang menjadi koordinator adalah Hugh Hawes dari Institute of Education University of London, yang kemudian dilanjutkan oleh Roy Gardner. Kerja sama ini diawali dengan kegiatan sains untuk SD dan kemudian dirintis Proyek Supervisi bagi guru SD di Kabupaten Cianjur, Jawa Barat yang dimulai pada tahun 1979. Proyek ini kemudian dinamakan Active Learning through Professional Support (ALPS) Project. Di Indonesia proyek ini dikenal sebagai Proyek CBSA (Cara Belajar Siswa Aktif). Selain itu, gagasan baru supervisi guru melalui forum kerja sama guru melalui Kelompok Kerja Guru (KKG), kepala sekolah melalui Kelompok Kerja Kepala Sekolah (KKKS), Kelompok Kerja PenilikSekolah(KKPS), dan PusatKegiatan Guru (PKG) secara resmi dimasukkan ke dalam pedoman pembinaan guru pada Kurikulum 1984.

Menurut UU No. 2 Tahun 1989 tentang Sistem Pendidikan Nasional, sebagai pendidikan umum, kurikulum pendidikan dasar wajib memuat sekurangkurangnya bidang-bidang kajian berikut:

1. Pendidikan Pancasila

2. Agama

3. Kewarganegaraan

4. Bahasa Indonesia

5. Membaca dan menulis

6. Matematika (termasuk berhitung)

7. Pengantar sains dan teknologi

8. Ilmu bumi

9. Sejarah nasional dan sejarah umum

10. Kerajinan tangan dan kesenian

11. Pendidikan jasmani dan kesehatan

12. Menggambar

13. Bahasa Inggris

Bidang-bidang itu bukan nama mata pelajaran tetapi nama kajian untuk membentuk kepribadian dan unsurunsur kemampuan yang diajarkan dan 
dikembangkan melalui pendidikan dasar. Lebih dari satu unsur kajian dapat digabung dalam satu mata pelajaran atau sebaliknya satu unsur kajian dapat dibagi ke dalam lebih dari satu mata pelajaran. Berdasarkan UU No.2/1989 Pasal 39, selanjutnya diatur oleh Keputusan Mendikbud No.060/U/1993, secara rinci kurikulum pendidikan dasar memuat 10 mata pelajaran:

1. Pendidikan Pancasila dan Kewarganegaraan

2. Pendidikan Agama

3. Bahasa Indonesia (termasuk membaca dan menulis)

4. Matematika (termasuk Berhitung)

5. Ilmu Pengetahuan Alam (pengantar sains dan teknologi)

6. Ilmu Pengetahuan Sosial (termasuk ilmu bumi, sejarah nasional dan sejarah umum)

7. Kerajinan Tangan dan Kesenian (termasuk menggambar

8. Pendidikan Jasmani dan Kesehatan

9. Bahasa Inggris, dan

10. Muatan lokal (sejumlah mata pelajaran).

\section{Kurikulum 1994 di SD}

Hasil-hasil dari Proyek Supervisi bagi guru SD yang kemudian dikenal dengan sebutan populer "Proyek CBSA" yang dimulai di Cianjur pada tahun 1979 kemudian direplikasi di Kota Mataram di Provinsi Nusa Tenggara Barat, Kabupaten Maros di Sulawesi Selatan, Kota Binjai di Sumatera Utara, Kota Bandar Lampung di Lampung, Kabupaten Sidoarjo di Jawa Timur, dan Kabupaten Tanah Laut di Kalimantan Selatan. Selain itu, Pusat Kurikulum juga bekerja sama dengan beberapa daerah lain dalam upaya replikasi ini. Sejalan dengan itu, direktorat sekolah dasar pada Ditjen Dikdasmen melakukan diseminasi melalui penataran terpusat dan kantor-kantor wilayah Depdikbud melakukan penataran tingkat provinsi yang dilanjutkan ke tingkat kebupaten dan kecamatan. Disamping itu, ada juga inisiatif sejumlah perguruan swasta yang bekerja sama dengan Pusat Kurikulum dan daerah-daerah binaan replikasi untuk menerapkan cara belajar siswa aktif. Penerbit swasta juga ikut mengupayakan introduksi atau integrasi pendekatan belajar aktif dalam buku pelajaran yang diterbitkan. Dasawarasa 1980-an adalah dasawarsa kegairahan mencoba dan menerapkan cara belajar siswa aktif. Proyek Supervisi atau CBSA itu secara resmi diakhiri pada tahun 1992 sejalan dengan keputusan ODA/DFID Pemerintah Inggris mengakhiri bantuan kepada proyek ini. Hasil-hasil pengembangan cara belajar siswa aktif dan supervisi guru ini dimasukkan ke dalam Kurikulum 1994 dan pedoman-pedomannya. Prinsipprinsip pengembangan kurikulum pada Kurikulum 1994 dikemukakan berikut ini:

1. Kegiatan belajar-mengajar dilaksanakan dengan sistem klasikal yang mengelompokkan anak dengan usia dan kemampuan rata-rata hampir sama menerima pelajaran dari seorang guru dalam mata pelajaran yang sama dalam waktu dan tempat yang sama. Bila diperlukan dapat dibentuk penglompokan sesuai dengan tujuan dan keperluan pengajaran.

2. Kegiatan belajar-mengajar pada dasarnya mengembangkan kemampuan psikis dan fisik serta kemampuan penyesuaian sosial siswa secara utuh. Dalam rangka mempersiapkan siswa untuk melanjutkan pendidikan ke jenjang pendidikan menengah atau 
memasuki lapangan kerja, perlu diusahakan pengembangan sikap bertanggung jawab dalam belajar dan mengemukakan pendapat, serta kemandirian dalam mengambil keputusan.

3. Mengingat anekaragamnya mata pelajaran, cara penyajian pelajaran hendaknya memanfaatkan berbagai sarana penunjang seperti kepustakaan, alat peraga, lingkungan alam dan budaya, serta masyarakat dan narasumber.

4. Kegiatan belajar-mengajar sebagai pembelajaran tambahan dapat diberikan kepada siswa baik yang akan melanjutkan ke pendidikan menengah maupun yang akan memasuki lapangan kerja/masyarakat umum. Siswa dapat mengikuti satu atau beberapa mata pelajaran sebagai pelajaran tambahan di luar jam pelajaran pada susunan program pengajaran, dengan jatah waktu yang sesuai dengan keadaan. Kegiatan pembelajaran tambahan dapat berupa kegiatan perbaikan atau kegiatan pengayaan.

(Sumber: Kurikulum Pendidikan Dasar: Landasan, Program, dan Pengembangan, Depdikbud, 1993).

Jika diamati secara teliti, dalam berbagai kurikulum (GBPP) mata pelajaran pendekatan belajar aktif menjadi warna yang menonjol. Dari segi penyajian isi kurikulum dalam GBPP, komponen kegiatan belajar amat ditekankan. Hal ini terlihat dari uraian tentang kegiatan belajar yang aktif yang merupakan porsi utama dan terbesar dalam keseluruhan GBPP. Khusus dalam kurikulum mata pelajaran Bahasa Indonesia dikembangkan dengan menggunakan pendekatan komunikatif (communicative approach) yang menekankan keterampilan berbahasa mengganti pendekatan struktural (structural approach) yang menekankan tata bahasa dalam kurikulum-kurikulum sebelumnya (Kurikulum 1947 s.d. Kurikulum 1984). Penerapan pendekatan komunikatif dalam Bahasa Indonesia berdampak juga kepada pengembangan kurikulum Bahasa Inggris SMP dan SMA yang menggunakan pendekatan yang sama.

Dengan demikian, dapatlah dikatakan bahwa pendekatan belajar aktif merupakan pendekatan pengembangan yang dianut dalam mengembangkan Kurikulum 1994. Pendekatan belajar aktif adalah implementasi pandangan konstruktivisme dalam belajar. Vygotsky (1978) menekankan konvergensi elemenelemen sosial dan praktis dalam belajar. Momen yang amat signifikan dalam lintasan perkembangan intelektual terjadi ketika berbicara (speech) dan kegiatan praktik, dua jalur perkembangan yang sebelumnya sepenuhnya tak saling tergantung (independen), berkonvergensi. Melalui kegiatan praktik seorang anak mengkonstruksi makna dalam dirinya (pada tingkat intra pribadinya), sedangkan berbicara menghubungkan makna ini dengan dunia antar-pribadi yang dishare oleh anak dan budayanya.

Dengan mengacu kepada Tap MPR No. IV/MPR/1978 tentang GBHN (Agama dan Kepercayaan kepada Tuhan Yang Maha Esa, Sosial-budaya): Dasar \& tujuan pendidikan nasional, UU No. 2/1989 tentang Sistem Pendidikan Nasional, dan PP dan PP No. 28 Tahun 1990 tentang Pendidikan Dasar serta hasil inovasi yang 
telah dilakukan, tersusunlah struktur program Kurikulum 1994 berikut ini:

1. Pendidikan Pancasila dan Kewarganegaraan

2. Pendidikan Agama

3. Bahasa Indonesia

4. Matematika

5. Ilmu Pengetahuan Alam

6. Ilmu Pengetahuan Sosial

7. Kerajinan Tangan dan Kesenian

8. Pendidikan Jasmani dan Kesehatan

9. Muatan Lokal

\section{Kurikulum 1984 di SMA}

Pengembangan Kurikulum 1984 SMA berpedoman pada azas-azas sebagai berikut :

1. Berlandaskan Pancasila, UUD 1945, dan GBHN

Kurikulum dikembangkan dengan berlandaskan Pancasila, Undangundang Dasar 1945, serta Garis-Garis Besar Haluan Negara yang berlaku, dalam kerangka mewujudkan citacita pembangunan nasional pada umumnya, dan tujuan pendidikan nasional pada khususnya.

2. Keluwesan

Kurikulum dikembangkan dengan mempertimbangkan baik tuntutan kebutuhan siswa pada umumnya maupun kebutuhan pada siswa secara perorangan sesuai dengan minat dan bakatnya, serta kebutuhan lingkungan. Hal ini diwujudkan melalui penyelenggaraan program inti dan program khusus (Pilihan), serta penggunaan sistem kredit.

3. Pendekatan Pengembangan

Pengembangan Kurikulum dilakukan secara bertahap dan terus-menerus, yaitu dengan jalan mengadakan penilaian terhadap pelaksanaan dan hasil- hasil yang telah dicapai untuk mengadakan perbaikan/pemantapan dan pengembangan lebih lanjut.

4. Peran Serta Daerah

Dalam pengembangan kurikulum ada pembagian kewenangan antara Pusat dan Daerah. Wewenang Pusat adalah mengembangkan konsep Program Inti dan Program Khusus (A dan B), sedangkan Daerah berwenang menjabarkan lebih lanjut pelaksanaan konsep tersebut, sesuai dengan cirri dan kondisi daerah, terutama Program B.

Materi Kurikulum 1984 pada dasarnya tidak banyak berbeda dengan materi Kurikulum 1975; yang berbeda adalah organisasi pelaksanaanya, sehingga dengan demikian Kurikulum 1984 dapat dilaksanakan dengan menggunakan bahan/buku- buku serta sarana yang ada. Perubahan yang diadakan lebih mengarah pada penyederhanaan materi setiap mata pelajaran sehingga mencakup hanya materi-materi yang penting saja. Dengan berkurangnya kepadatan materi kurikulum, hal itu memungkinkanterlaksananya kegiatan belajar mengajar yang lebih baik.

Struktur program kurikulum 1984 sekolah menengah umum tingkat atas untuk program pilihan A Kurikulum 1984 SMA dilaksanakan secara bertahap mulai dengan I pada tahun ajaran 1984/1985, kelas I dan kelas II pada tahun ajaran 1985/1986; dan kelas I, kelas II, kelas III pada tahun ajaran 1986/1987; dan seterusnya. Program A adalah dalam rangka menyiapkan siswa yang memenuhi persyaratan untuk melanjutkan pendidikannya ke perguruan tinggi. 


\section{Kurikulum 1994 di SMA}

Dengan berlakunya Undang-undang Republik Indonesia Nomor 2 Tahun 1989 tentang Sistem Pendidikan Nasional serta sekalian peraturan pemerintah sebagai pedoman pelaksanaannya, maka kurikulum Sekolah Menengah Umum perlu disesuaikan dengan peraturan perundang-undangan tersebut.

Kurikulum disusun untuk mewujudkan tujuan pendidikan nasional dengan memperhatikan tahap perkembangan siswa dan kesesuaiannya dengan lingkungan, kebutuhan pembangunan nasional, perkembangan ilmu pengetahuan dan teknologi serta kesenian, sesuai dengan jenis dan jenjang masing-masing satuan pendidikan (Pasal 37 Undang-Undang Nomor 2 Tahun 1989 tentang Sistem Pendidikan Nasional).

Sehubungan dengan hal-hal tersebut diatas, maka ditetapkan Keputusan Menteri Pendidikan dan Kebudayaan Nomor: 061/U/1993 Tanggal 25 Februari 1993 tentang Kurikulum Sekolah Menengah Umum sebagaimana tercantum dalam Lampiran I tentang Landasan, Program dan Pengembangan Kurikulum Sekolah Menengah Umum, Lampiran II tentang Garis-garis Besar Program Pengajaran, dan Lampiran III tentang Pedoman Pelaksanaan Kurikulum.

Buku Landasan, Program dan Pengembangan Kurikulum Sekolah Menengah Umum memuat hal-hal pokok sebagai berikut: Landasan yang dijadikan acuan dan pedoman dalam pengembangan kurikulum; tujuan pendidikan nasional, tujuan pendidikan menengah dan tujuan pendidikan pada Sekolah Menengah Umum; program pengajaran yang mencakupisi program pengajaran, lama pendidikan dan susunan program pengajaran; pelaksanaan pengajaran; penilaian dan pengembangan kurikulum selajutnya, di tingkat nasional dan tingkat daerah.

1) Program Pengajaran Umum

Program pengajaran umum merupakan program pengajaran yang wajib diikuti oleh semua siswa kelas I dan kelas II. Program ini dimaksudkan untuk meningkatkan kemampuan siswa sebagai anggota masyarakat dalam mengadakan hubungan timbal balik dengan lingkungan sosial, budaya, dan alam sekitarnya serta meningkatkan pengetahuan, kemampuan, dan minat siswa sebagai dasar untuk memilih program pengajaran khusus yang sesuai di kelas III. Program pengajaran umum mencakup bahan kajian dan pelajaran yang disusun dalam mata pelajaran sebagai berikut:

\section{Pendidikan Pancasila dan}

Kewarganegaraan

2. PendidikanAgama

3. Bahasa dan Sastra Indonesia

4. Sejarah Nasionaldan Sejarah Umum

5. Bahasa Inggris

6. Pendidikan Jasmani dan Kesehatan

7. Matematika

8. Ilmu Pengetahuan Alam
a. Fisika
b. Biologi
c. Kimia

9. Ilmu Pengetahuan Sosial
a.Ekonomi
b.Sosiologi
c. Geografi

10. Pendidikan Seni 


\section{2) Program Pengajaran Khusus}

Program Pengajaran Khusus diselenggarakan di kelas III dan dipilih oleh siswa sesuai dengan kemampuan dan minatnya. Program ini dimaksudkan untuk mempersiapkan siswa melanjutkan pendidikan pada jenjang pendidikan tinggi dalam bidang pendidikan akademik maupun pendidikan professional dan mempersiapkan siswa secara langsung atau tidak langsung untuk bekerja di masyarakat.

Siswa dikelasIIIdiberipeluanguntuk berpindah ke program pengajaran khusus lainnya sesuai dengan kemampuan, minat, dan kemajuan belajarnya. Kesempatan untuk berpindah dari program khusus yang telah dipilihnya ke program khusus lainnya diberikan sampai dengan akhir catur wulan I kelas III.

Program pengajaran khusus terdiri dari: Program Bahasa, Program Ilmu Pengetahuan Alam, dan Program Ilmu Pengetahuan Sosial. Setiap program khusus terdiri dari sejumlah mata pelajaran umum dan mata pelajaran khusus.

Jenis mata pelajaran umum dan jumlah jam pelajaran masing-masing mata pelajaran umum pada setiap program khusus adalah sama. Mata-mata pelajaran pada setiap program khusus adalah sebagai berikut:

\section{a. Program Bahasa}

Program ini dimaksudkan untuk mempersiapkan siswa melanjutkan pendidikannya ke jenjang pendidikan tinggi yang berkaitan dengan bahasa dan budaya, baik dalam bidang pendidikan akademik maupun pendidikan profesional. Selain daripada itu, program inijuga memberikan bekal kemampuan kepada siswa secara langsung atau tidak langsung untuk bekerja di masyarakat. Program pengajaran ini berisi bahan kajian dan pelajaran yang disusun dalam mata pelajaran berikut:

a) Mata Pelajaran Umum:

1)Pendidikan Pancasila dan Kewarganegaraan,

2) Pendidikan Agama,

3)Bahasa dan Sastra Indonesia,

4)SejarahNasional dan Sejarah Umum,

5)Bahasa Inggris,

6)Pendidikan Jasmani dan Kesehatan.

b) Mata Pelajaran Khusus

1)Bahasa dan Sastra Indonesia

2)Bahasa Inggris,

3)Bahasa Asing Lain,

4)Sejarah Budaya.

b. Program Ilmu Pengetahuan AIam (IPA)

Program 1lmu Pengetahuan Alam dimaksudkan untuk mempersiapkan siswa melanjutkan pendidikan ke jenjang pendidikan tinggi yang berkaitan dengan matematika dan ilmu pengetahuan alam baik dalam bidang pendidikan akademik maupun pendidikan profesional. Selain daripadaitu, program ini juga memberikan bekal kemampuan kepada siswa secara langsung atau tidak langsung untuk bekerja di masyarakat. Program ini berisi bahan kajian dan pelajaran yang disusun dalam mata pelajaran berikut:

a) Mata Pelajaran Umum

1) Pendidikan Pancasila dan Kewarganegaraan,

2) Pendidikan Agama,

3) Bahasa dan Sastra Indonesia,

4) Sejarah Nasional dan Sejarah Umum, 
5) Bahasa Inggris,

6) Pendidikan Jasmani dan Kesehatan.

b) Mata Pelajaran Khusus
1) Fisika,
2) Biologi,
3) Kimia
4) Matematika.

\section{c. Program Ilmu Pengetahuan Sosial}

Program ini dimaksudkan untuk mempersiapkan siswa I melanjutkan pendidikannya ke jenjang pendidikan tinggi yang I berkaitan dengan ilmu pengetahuan sosial, baik dalam bidang pendidikanakademik maupun pendidikan profesional. Selain daripada itu, program ini juga memberikan bekal kemampuan kepada siswa secara langsung atau tidak langsung untuk bekerja di masyarakat. Program pengajaran ini berisi bahan kajian dan pelajaran yang disusun dalam mata pelajaran berikut:

Program pengajaran ini berisi bahan kajian dan pelajaran yang disusun dalam mata pelajaran berikut:

a) Mata pelajaran Umum
1) Pendidikan Pancasila dan Kewarganegaraan,
2) PendidikanAgama,
3) Bahasa dan Sastra Indonesia,
4) Sejarah Nasional dan Sejarah Umum,
5) Bahasa Inggris,
6) Pendidikan Jasmani dan Kesehatan.
a) Mata Pelajaran Khusus
1) Ekonomi,
2) Sosiologi,
3) Tata Negara,
4) Antropologi.
D. Penutup

Orde baru berlangsung dari tahun 1968 hingga 1998, dan dapat dikatakan sebagai era pembangunan nasional. Pada pendidikan orde baru kesetaran dalam pendidikan tidak dapat diciptakan karena unsur dominatif dan submisif masih sangat kental dalam pola pendidikan orde baru. Pada dua periode pertama kekuasaan Soeharto (1968-1973 dan 1973-1978), pendidikan sebagai wahana pembelajaran dan penggodokan calon pemimpin masih Dalam hal intervensi terhadap pendidikan, kebijakan Orde Baru mirip kebijakan kolonial. Ada beberapa kebijakan pokok dalam pendidikan pada masa orde baru, yaitu: relevansi pendidikan, pemerataan pendidikan, peningkatan mutu guru atau tenaga kependidikan. Pengembangan Kurikulum $1984 \quad$ menggunakan pendekatan keterampilan proses (process skill approach). pendekatan belajar aktif merupakan pendekatan pengembangan yang dianut dalam mengembangkan Kurikulum 1994.

\section{Daftar Pustaka}

A. Zakki Fuad, Sejarah Pendidikan Islam. (Surabaya: IAIN Sunan Ampel, 2011) hal-154.

Arskal Salim, Islam di Antara Dua Model Demokrasi, dalam: Wajah Liberal Islam di Indonesia, Jakarta: TUK, 2002, Hal. 27.

Fred R. Von der Mehden, "Malaysia dan Indonesia", Shireen T. Hunter (ed.) Politik Kebangkitan Islam: Keragaman dan Kesatuan. (Yogya: Tiara Wacana, 2001), hal. 272.

H. Samsul Nizar, Sejarah Pendidikan Islam (Jakarta: Kencana, 2007), hal-361

http://tanjungpinangarticle.blogspot. com/2010/06/pendidikan-padamasa-orde-lama-dan-orde.html 
Ikrar Nusa Bhakti, Berbagai Faktor Penyebab Jatuhnya Presiden Soeharto, dalam Pers Dalam "Revolusi Mei" Runtuhnya Sebuah Hegemoni, Dedy N. Hidayat, dkk. Jakarta: Gramedia Pustaka Utama, 2000, Hal. 61.

Khaerul Wahidin dan Drs. Taqiyuddin, Sejarah Pendidikan Islam Umum \& Indonesia, Cirebon: Biro penerbit Fakultas Tarbiyah IAIN Sunan

Gunung Djati Cirebon. 1996, hal. 2.

R. Hrair Dekmejian, Kebangkitan

Islam: Katalisator, Kategori, dan Konsekuensi, Politik Kebangkitan Islam: Keragaman dan kesatuan, Shireen T. Hunter (ed.) (Yogyakarta: Tiara Wacana Wacana, 2001) hal. 3.

Sudirman, Pembaharuan Hukum Islam : Mempertimbangkan Harun Nasution, dalam Refleksi Pembaharuan Pemikiran Islam, Jakarta: LSAF, 1989, Hal. 153

Zainuddin Maliki, Agama Priyayi, Makna di tangan Elite Penguasa, Yogyakarta: Pustaka Marwa, 2004, Hal. 6 